\title{
Central African Republic: Request for a Three-Year Arrangement Under the Extended Credit Facility - Staff Report; Press Release on the Executive Board Discussion; and Statement by the Executive Director for Central African Republic.
}

In the context of the request for a three-year arrangement under the extended credit facility, the following documents have been released and are included in this package:

- $\quad$ The staff report for the request for a three-year arrangement under the Extended Credit Facility, prepared by a staff team of the IMF, following discussions that ended on April 19, 2012, with the officials of Central African Republic on economic developments and policies. Based on information available at the time of these discussions, the staff report was completed on June 11,2012. The views expressed in the staff report are those of the staff team and do not necessarily reflect the views of the Executive Board of the IMF.

- A Press Release summarizing the views of the Executive Board as expressed during its June 25, 2012 discussion of the staff report that completed the request and/or review.

- $\quad$ A statement by the Executive Director for Central African Republic.

The documents listed below have been or will be separately released.

Letter of Intent sent to the IMF by the authorities of Central African

Republic*

Memorandum of Economic and Financial Policies by the authorities of

Central African Republic*

Technical Memorandum of Understanding*

*Also included in Staff Report

The policy of publication of staff reports and other documents allows for the deletion of market-sensitive information.

\author{
Copies of this report are available to the public from \\ International Monetary Fund • Publication Services \\ $70019^{\text {th }}$ Street, N.W. • Washington, D.C. 20431 \\ Telephone: (202) 623-7430 • Telefax: (202) 623-7201 \\ E-mail: publications@imf.org Internet: http://www.imf.org
}

\section{International Monetary Fund Washington, D.C.}




\title{
INTERNATIONAL MONETARY FUND
}

\section{CENTRAL AFRICAN REPUBLIC}

\section{Request for a Three-Year Arrangement Under the Extended Credit Facility}

\author{
Prepared by the African Department \\ (In consultation with other departments) \\ Approved by Paul Mathieu and Dhaneshwar Ghura
}

June 11,2012

Relations with the IMF: The authorities of the Central African Republic (C.A.R.) are requesting a three-year arrangement under the Extended Credit Facility (ECF) with access equal to 75 percent of quota to support their medium-term economic program. C.A.R. successfully completed a three-year ECF-supported program in September 2010. The Executive Board concluded the 2011 Article IV consultation on January 30, 2012.

Discussions: Discussions on the ECF-supported program took place in Bangui April 4-19, 2012. The team comprised Messrs. Toé (head), Ramirez, and Yehoue (all AFR), Mr. Jamaludin (SEC), and Mr. Bua (resident representative). Representatives of the African Development Bank (AfDB), the European Union (EU), and the World Bank participated in the mission. Mr. Tall (Office of the Executive Director) attended some policy discussions. The mission met with President Bozizé; the President of the National Assembly, Celestin Gaombalet; Prime Minister Touadéra; then Minister of State for Finance and Budget Ndoutingaï; other ministers and senior officials, representatives of civil society, labor unions, donors, and the private sector. On June 1, Mr. Ndoutingaï was replaced by former Finance Minister Albert Besse.

Program objectives: (i) consolidate macroeconomic stability by restoring fiscal discipline, (ii) create fiscal space for increased spending on critical social programs and basic infrastructure, (iii) strengthen policy implementation capacity, and (iv) accelerate structural reforms to remove impediments to growth.

Political and security situation: The disarmament, demobilization, and reintegration (DDR) process was relaunched in May following the release of the First Vice-President of the DDR Steering Committee who had been arrested in January 2012. This bodes well for the consolidation of peace and improvement in the security situation, which nonetheless remains fragile.

Publication: The authorities have consented to publication of the staff report, the updated Debt Sustainability Analysis, the Letter of Intent, Memorandum of Economic and Financial Policies and the Technical Memorandum of Understanding. 


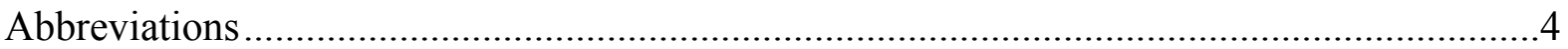

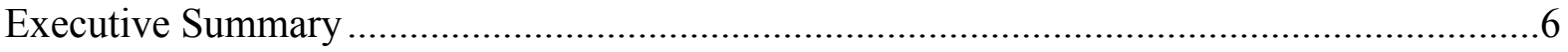

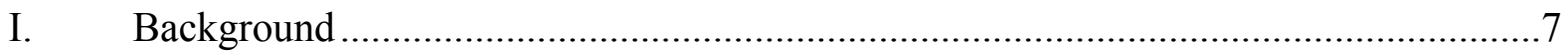

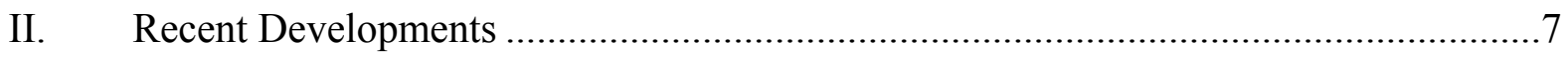

III. The Proposed Three-Year Reform Program .....................................................

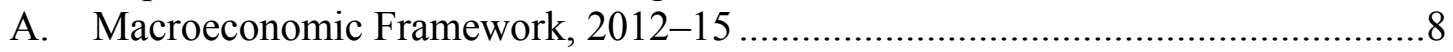

B. Medium-Term Structural Policies................................................................. 13

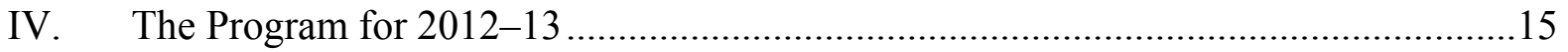

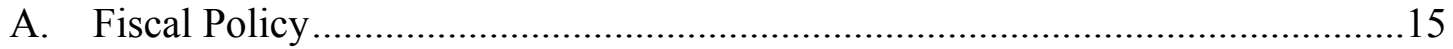

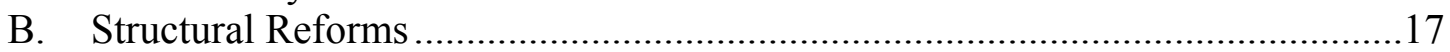

V. Program Conditionality, Monitoring, Access, Financing Assurances, and Risks .......17

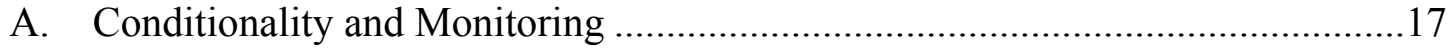

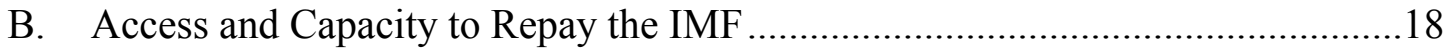

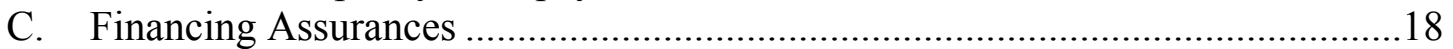

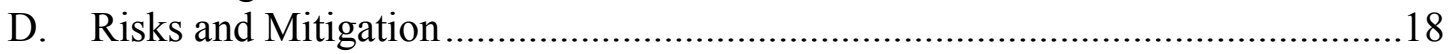

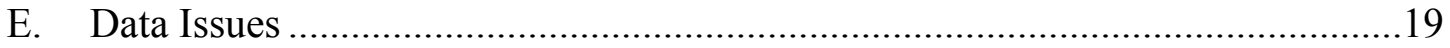

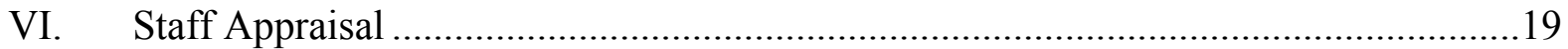

VII. Three-Year Arrangement under the Extended Credit Facility.................................34

Boxes

1. Strengthening Natural Resource Management .......................................................9

2. Second-Generation Poverty Reduction Strategy Paper, 2011-15 ............................11

3. Strengthening Public Financial Management ....................................................... 14

4. Improving Confidence in the Budget Process ................................................... 16

Figures

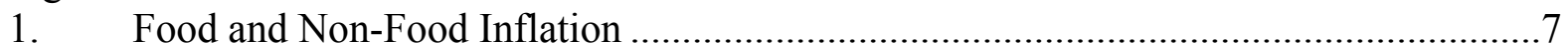

2. Medium-Term Macroeconomic Prospects, 2006-16...............................................12

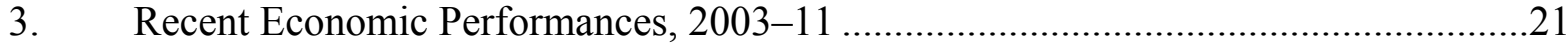

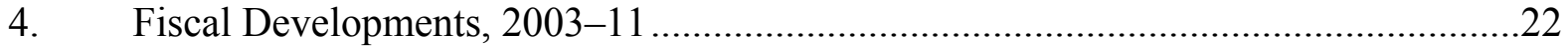

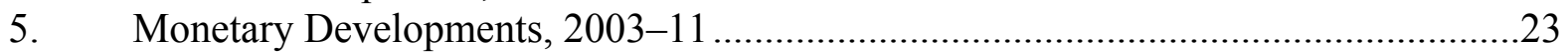

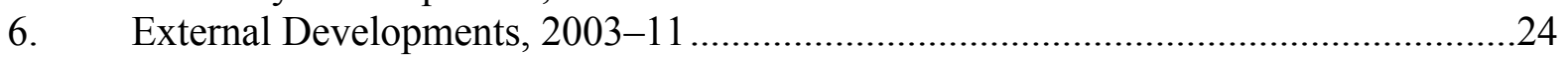




\section{Text Tables}

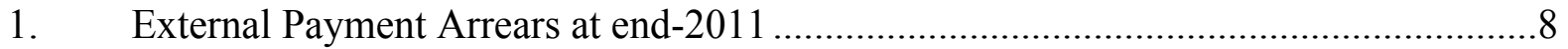

2. Selected Macroeconomic Indicators, 2010-15 .........................................................

\section{Tables}

1. Selected Economic and Financial Indicators, 2009-15 …......................................25

2. Central Government Financial Operations, 2009-15 ..........................................26

3. Central Government Financial Operations, 2009-15 ..........................................27

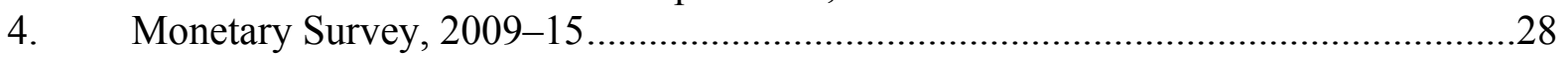

5. Balance of Payments, 2009-15 ........................................................................29

6. Access and Phasing Under the Three-Year ECF Arrangement ................................30

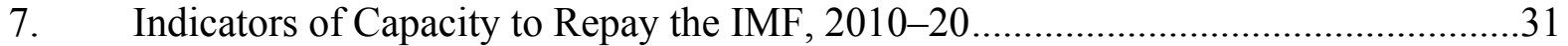

8. Selected Financial Soundness Indicators, 2007-11 ................................................32

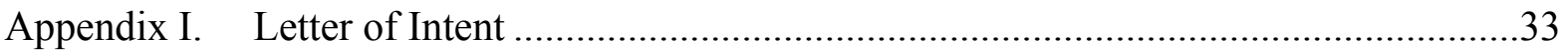

Attachment I. Memorandum of Economic and Financial Policies ........................35

Attachment II. Technical Memorandum of Understanding...................................48

Appendix II. Updated Debt Sustainability Analysis Using the Low-Income Country

Framework ..............................................................................58 


\section{AbBreviations}

AfDB

BEAC

CBCA

CEMAC

CNDP

COBAC

$\mathrm{CPC}$

CSGB

CSL

CTSL

DDP

DDR

DGID

DSA

ECCAS

$\mathrm{ECF}$

EIB

EITI

EU

FDI

FSAP

GFMIS

HIPC

IFC

IPD

LIC

MDG

MDRI

MEFP

MTEF

NEPAD

NFA

PC

PEFA

PFM

PRGF

PRSP

SB
African Development Bank

Banque des états de l'Afrique centrale

(Bank of Central African States)

Commercial Bank - Centrafrique

Communauté économique et monétaire de l'Afrique centrale

(Economic and Monetary Community of Central Africa)

National Committee on Public Debt

Central African Banking Commission

Standing Consultative Group

Budget Management Monitoring Committee

Liquidity Monitoring Commission

Technical Unit on Liquidity Monitoring

Department of Debt and Equity Participation

Disarmament, Demobilization, and Reintegration

The Revenue Authority

Debt Sustainability Analysis

Economic Community of Central African States

Extended Credit Facility (replaced PRGF)

European Investment Bank

Extractive Industries Transparency Initiative

European Union

Foreign direct investment

Financial Sector Assessment Program

Government Financial Management Information System

Heavily Indebted Poor Countries

International Finance Corporation

Inclusive political dialogue

Low-income countries

Millennium Development Goal

Multilateral Debt Relief Initiative

Memorandum of economic and financial policies

Medium-Term Expenditure Framework

New Partnership for Africa's Development

Net foreign assets

Performance criterion

Public Expenditure and Financial Accountability

Public financial management

Poverty Reduction and Growth Facility

Poverty Reduction Strategy Paper

Structural benchmark 


$\begin{array}{ll}\text { SOE } & \text { State-owned enterprise } \\ \text { TA } & \text { Technical assistance } \\ \text { TFPs } & \text { Technical and financial partners } \\ \text { TIN } & \text { Tax identification number } \\ \text { TMU } & \text { Technical memorandum of understanding } \\ \text { TSA } & \text { Treasury single account } \\ \text { TUPP } & \text { Taxe unitaire sur produits pétroliers } \\ \text { UMAC } & \text { Central African Monetary Union } \\ \text { VAT } & \text { Value-added tax }\end{array}$




\section{EXECUTIVE SUMMARY}

Despite the progress achieved since emerging from conflict in 2003, the Central African Republic (C.A.R.) remains a fragile state. The protracted electoral process in 2010 created uncertainty and exposed C.A.R.'s vulnerabilities, reversing most of the hard-won gains under the previous ECF-supported program. Election-related fiscal slippages of 2010/11 delayed discussions on a successor ECF arrangement, but the authorities have since taken corrective measures and committed to implement a comprehensive reform agenda.

Fund reengagement takes into account the unique challenges facing the C.A.R. It seeks to catalyze donor resources from a very low level and enhance coordination for effective TA delivery and capacity building.

The main challenge is to transition out of fragility through the sustained implementation of sensible macroeconomic and structural policies. Near-term challenges are to strengthen budget execution, improve public financial management (PFM) and governance to attract much-needed financial support, and enhance the efficiency of public spending. Longer-term policy challenges are to (i) diversify the economy to achieve sustained high and inclusive growth, which will require scaling up investment in basic infrastructure and improving competitiveness; and (ii) improve the business climate to promote greater private sector participation in the economy and create employment opportunities.

The authorities' proposed medium-term macroeconomic program addresses the key challenges facing C.A.R. Policies and structural reform measures aim at (i) consolidating the fiscal position in 2012 while aligning expenditure with available resources; (ii) creating fiscal space for poverty reduction and investment in infrastructure through stronger domestic resource mobilization and prioritization of government expenditure; (iii) improving PFM and governance; (iv) enhancing donor coordination and leveraging technical assistance (TA) resources to strengthen capacity and institutions; and (v) accelerating structural reforms to remove impediments to growth and deepening financial intermediation.

Staff supports the authorities' request for a three-year arrangement under the ECF. IMF financial assistance would buttress C.A.R.'s reform efforts, help address C.A.R.'s protracted balance of payments problem and close the financing gap, and catalyze donors' assistance for much-needed concessional financing for poverty reduction and progress toward the Millennium Development Goals (MDGs). 


\section{BACKGROUND}

1. Political and economic uncertainties in C.A.R. have abated, but the sociopolitical environment remains fragile. Nine years after the end of the civil conflict and two presidential elections won by President Bozizé (2005 and 2011), the political situation remains fractious and some areas of the country are under the control of rebel groups. ${ }^{1}$ Institutional weaknesses, limited and volatile aid flows, and persistently low domestic resource mobilization have frustrated the authorities' efforts and considerably slowed the transition out of fragility. The proposed program acknowledges C.A.R. fragility and focuses on donor coordination to mobilize financial and TA to help build capacity.

\section{RECENT DEVELOPMENTS ${ }^{2}$}

\section{Growth in 2011 was stronger than previously estimated and inflation is} accelerating. Real GDP growth has been revised upward to 3.3 percent for 2011 on the back of strong agriculture and mining activity. Reversing the downward trend since it peaked in 2008, inflation accelerated starting in November 2011 driven by price gouging and supply disruptions. As a result, headline inflation reached 7.8 percent in March 2012 (y-o-y); but because price pressures are expected to ease later in the year, annual inflation would be contained at 6.8 percent for the year as a whole.

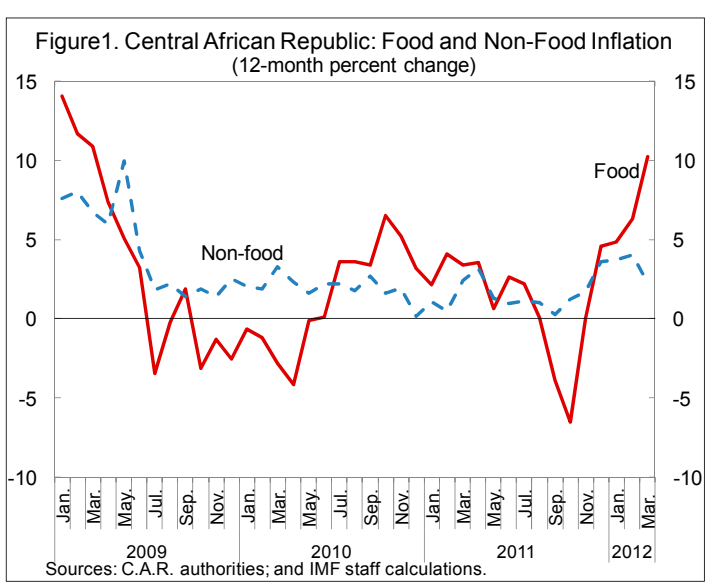

\section{Budget execution through end-March 2012 was broadly in line with the} program. Lower-than-budgeted tax revenue largely stemming from the nonadjustment of domestic petroleum prices since January $2012^{3}$ was offset by exceptional nontax revenues. Expenditure was below budget allocations, but an unplanned liquidity injection (CFAF 5.5 billion) in the capital of an intervened bank resulted in a lower-than-programmed domestic primary fiscal surplus. The authorities adjusted pump prices on June 1 (prior action) and committed to further monthly adjustments to eliminate subsidies and safeguard the

\footnotetext{
${ }^{1}$ The Lord's Resistance Army (LRA) from Uganda and the Front populaire pour le redressement (FPR) from Chad are reported to have bases in C.A.R..

2 Since the Staff Report for the 2011 Article IV consultation (SM/12/12), considered by the Executive Board on January 30, $2012(\mathrm{EBM} / 12 / 10)$.

${ }^{3}$ This resulted in a buildup of subsidies amounting to CFAF 1.2 billion ( 0.1 percent of GDP) during the first quarter.
} 
program's revenue objectives (MEFP 919). The authorities have started preparing monthly cash-flow plans to avoid expenditure overruns; the first plan provided the basis for setting ceilings on spending commitments (MEFP q20).

\section{The authorities are addressing external payment arrears that have built up} starting in late 2010. These represented 1.1 percent of GDP at end-December 2011. Clearance of the arrears to France and the European Investment Bank (EIB) is to take place before approval of the ECF arrangement, and the authorities are making best efforts to conclude bilateral agreements with Russia and the United Kingdom. For non-Paris Club creditors, they are pursuing negotiations to obtain debt relief on terms comparable to those granted by Paris Club creditors and are making good faith efforts to

\begin{tabular}{|lr|}
\hline \multicolumn{2}{|c|}{ Text Table1. Central African Republic: } \\
\multicolumn{2}{|c|}{ External Payment Arrears at end-2011 } \\
\hline Creditors & (US\$ millons) \\
\hline Bilateral & 19.7 \\
Paris Club (France) & 2.0 \\
Non-Paris Club & 17.7 \\
Multilateral (EIB) & 0.7 \\
Private Creditors & 2.6 \\
Total & 22.9 \\
\hline Source: C.A.R. authorities. \\
\hline
\end{tabular}
reach collaborative agreements with external private creditors (MEFP \6).

5. The structural reform agenda is on track. Steps have been taken to streamline and strengthen the committees and units in charge of liquidity management and monitoring of macroeconomic and structural reforms. The revenue administration implemented measures aimed at enhancing its performance, notably through (i) updating taxpayer files; (ii) enhancing the registration procedure; and (iii) improving the efficiency of tax control (better use of intelligence, streamlining of programming, higher quality audits) (MEFP 98 ).

\section{The Proposed Three-Year Reform Program}

\section{A. Macroeconomic Framework, 2012-15}

6. The medium-term macroeconomic framework discussed in the $\mathbf{2 0 1 1}$ Article IV consultation report remains broadly valid. Real GDP growth is projected to accelerate to about 6 percent by 2014 , on the back of (i) continued strength in agricultural production; (ii) a recovery in private sector investment in the mining sector driven by foreign direct investment (FDI) inflows; and (iii) a rebound in external demand. Inflation is expected to return to levels within the

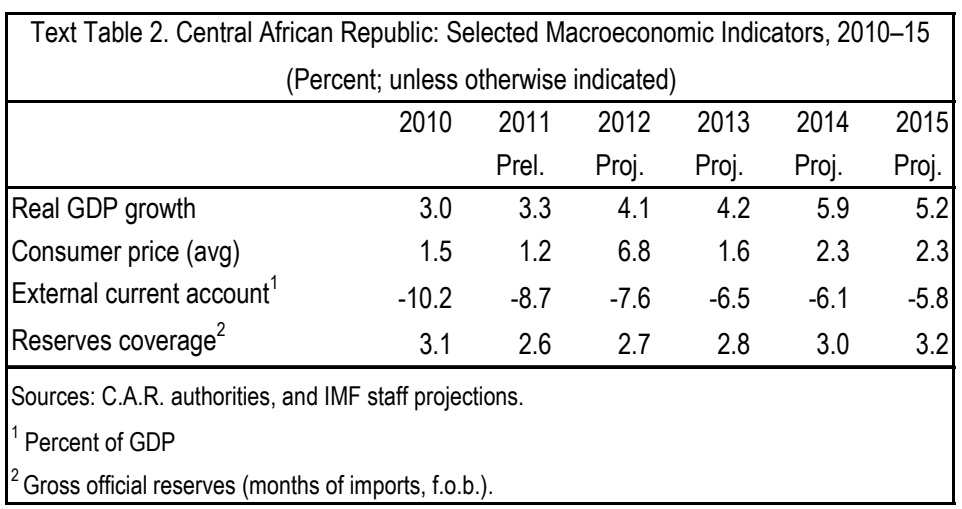
CEMAC convergence rate of 3 percent starting in 2013. 


\section{Box 1. Strengthening Natural Resource Management ${ }^{1}$}

C.A.R.'s natural mineral resources have not been tapped on a large scale. Mineral exploitation is currently entirely dominated by artisanal production and concentrated mainly on diamond mining and, to a lesser degree, gold. There are proven deposits of diamonds, gold, and uranium. Oil exploration is underway in some parts of the country.

The Passendro Gold Mining Project. Located in the south central region, 170 miles northwest of the capital, Bangui the project features a 25-year mining license covering 137 square miles and two surrounding exploration licenses covering 386 square miles. The total capital costs of the project are expected to be about US $\$ 270$ million. The International Finance Corporation (IFC) is considering participating in the project with US\$50 million equally divided in equity and debt to a Canadian-based company, AXMIN, which has a strong presence in central and western Africa. IFC's involvement in the development of this gold mining project is consistent with its ongoing engagement in bolstering postconflict reconstruction efforts in C.A.R. The IFC has agreed to play a lead role in coordinating the overall financing package for a group of development finance institutions. The IFC's commitment to arranging this financing package is subject to satisfactory technical, legal and environmental due diligence, execution of acceptable terms and documentation, as well as obtaining final Credit Committee and Executive Board approvals. IFC has already started the process of appraising the project.

Expected Impact. Successful development of the Passendro Project would likely catalyze mineral exploration in C.A.R. and create incentives for other mining companies to explore business opportunities in the country. As the first industrial mine in the country, the project can also establish benchmarks for environmental, social, and community practices, in line with IFC's Performance Standards. C.A.R. has demonstrated a commitment to extractive industry revenue transparency by attaining EITI compliant status in March 2011. Although revenue flows to the government arising from the project are expected to be moderate, the project will contribute to broadening C.A.R.'s limited revenue base. In addition, the mine is expected to employ between 615 and 670 workers, mainly local hires. The project will generate employment throughout the supply chain as well, an effect which could be magnified with technical assistance from the IFC's Advisory Services through IFC's linkage programs. It will also support community development initiatives to increase the percentage of locally distributed revenue.

Framework for Natural Resource Management. TA will be provided by the IMF and other organizations to assist the authorities in putting in place legislation that is in line with international best practices and would ensure C.A.R. gets the most out of the exploitation of its natural resources. In particular, the Fiscal Affairs Department of the IMF will provide a deskbased assessment of the mining code and determine further TA needs, based on the conclusions of the assessment.

${ }^{1}$ This box was drafted with the assistance of Justin Kouakou (IFC). 
7. The external current account deficit is expected to decline gradually in the medium term. This is predicated on a gradual improvement in the terms of trade and a pickup in FDI and official transfers as donors resume disbursement of external aid. However, while recovering modestly, the reserves position would remain weak with import coverage reaching just three months by 2014 .

\section{Natural resource exploitation over the medium term is expected to support} growth and fiscal revenue (Box 1). Projects underway include a gold mining project supported by the IFC (total investment representing 13.2 percent of GDP) and petroleum exploration by a Chinese firm. These projects constitute a significant challenge in terms of resource management; and the government will need TA, including from the IMF, to put in place a framework that promotes transparency in the management of these resources (MEFP $\mid 28)$. C.A.R. is a member of the Extractive Industries Transparency Initiative (EITI).

9. The macroeconomic framework will be revised to allow for increased investment and social spending when financing becomes available. Although the baseline scenario is conservatively based on historical trends of donors' disbursements, the program objectives are in line with the strategic priorities of the second-generation Poverty Reduction Strategy Paper (PRSP II) (Box 2) (MEFP 93). C.A.R., along with six other countries, is part of a pilot for donors to implement a "New Deal" for engaging in fragile states and an integrated strategy by donors is expected to be developed in September 2012. Key elements of the IMFsupported program will be an integral part of the integrated strategy. Also, a Consultative Group (CG) meeting is expected to be held before end-2012 to mobilize financing for the PRSP II. With the prospect of increased financing, the macroeconomic framework will be revised and efforts will be made with donors to identify "quick wins" that would bolster support for the government's reform agenda.

10. The medium-term growth outlook is positive, but with significant risks. These relate to a possible deterioration in the security and political situation and a weakening of the external environment, particularly in the euro area, C.A.R.'s main export market. 


\section{Box 2. Second-Generation Poverty Reduction Strategy Paper, 2011-15}

The PRSP II builds on the first PRSP (2006-10), which mapped out the strategy for C.A.R.'s postconflict reconstruction. Reflecting limited resources and implementation capacity —on average only half of the priority actions were completed - C.A.R.'s progress toward achieving the MDGs was limited. The PRSP II has three strategic pillars:

$>$ Consolidation of security and peace, and strengthening governance and rule of law;

$>\quad$ Economic revival and regional integration; and

$>$ Development of human capital and essential social services.

The PRSP II presents two scenarios. Scenario I, dubbed "Locking the C.A.R. into the Dynamics of Regional Integration and Fast Progress Toward the MDGs," assumes implementation of major projects in a regional context involving the CEMAC, the Economic Community of Central African States, the New Partnership for Africa's Development (NEPAD) and the Congo Basin with financing requirements of US $\$ 9.8$ billion (504.6 percent of 2010 GDP) for 2011-15. Scenario II is less ambitious and assumes the implementation of national projects to sustain growth with a required financing of US $\$ 5.5$ billion (283.4 percent of 2010 GDP).

Under both scenarios, development of infrastructure, economic revival through revitalization of agriculture and enhanced regional integration take up the bulk of total financing. The second pillar of the PRSP II is supported by a Rural Sector Development Strategy, which places a heavy emphasis on ensuring food security.

At a development partners' roundtable convened in June 2011 in Brussels, participants recommended that the government streamline the PRSP II with realistic financing requirements. The World Bank is assisting the authorities with preparation of a Priority Action Plan for presentation to the CG meeting ( $(99)$.

The IMF-supported ECF program, designed to support the poverty reduction agenda, is aligned with the priorities of the PRSP II. Although the quantitative objectives of the first year reflect the severely constrained resources, the expectation is that the CG meeting will provide an opportunity for more meaningful donor reengagement. The program has the built-in flexibility to provide a strong basis for the attainment of the key objectives of the PRSP II should financing be made available. Through its emphasis on restoring fiscal discipline and creating fiscal space, the program is expected to encourage better management and mobilization of domestic resources that can be channeled toward poverty reduction. 
Figure 2. Central African Republic: Medium-Term Macroeconomic Prospects, 2006-16

Growth is expected to recover in the medium term...

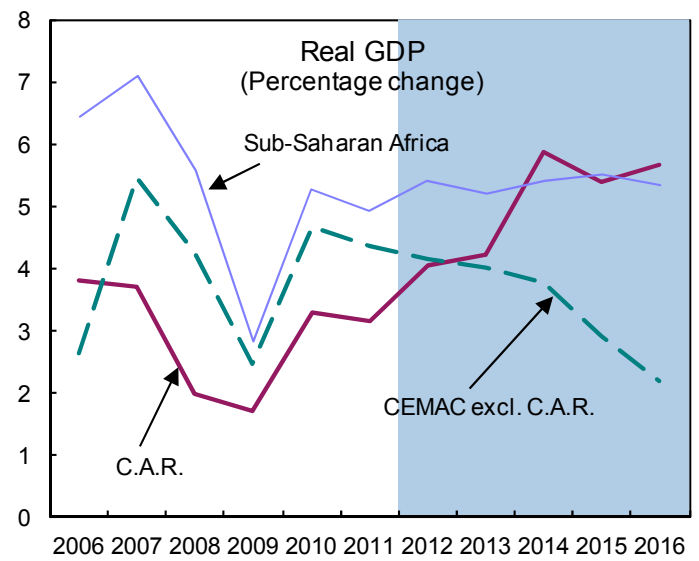

Total revenues would rise slowly...

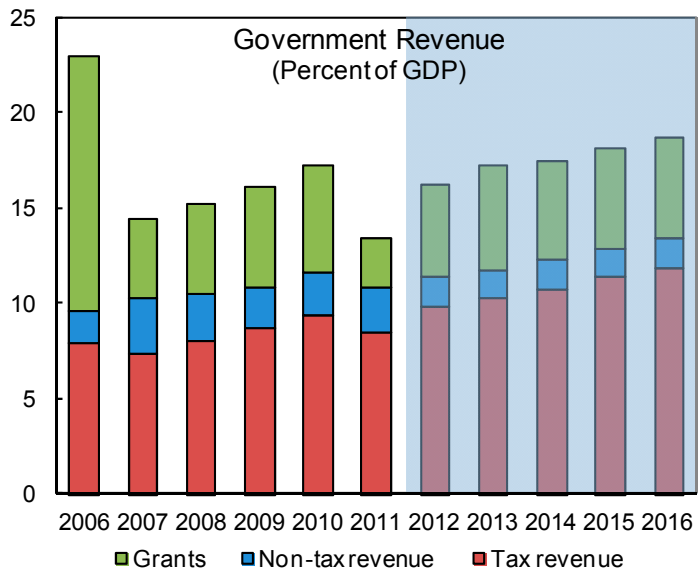

The fiscal position would improve under the ECF arrangement..

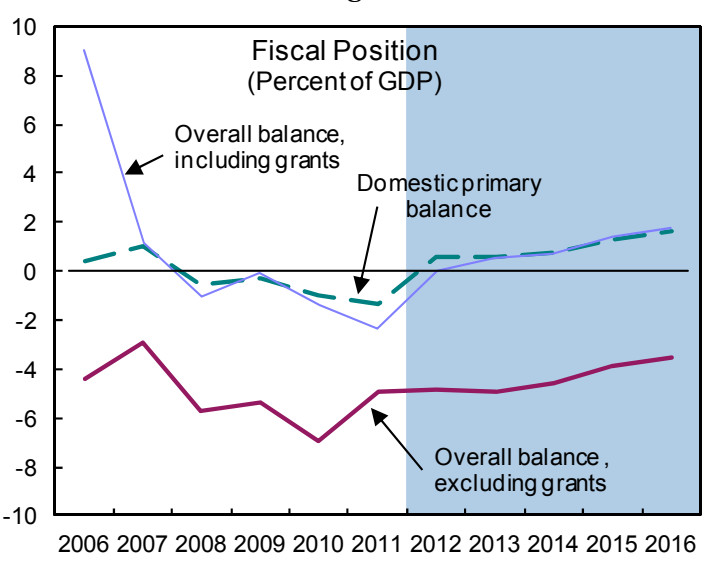

Sources: C.A.R. authorities; and IMF staff estimates.
... and inflation to stabilize at low levels after a surge in 2012.

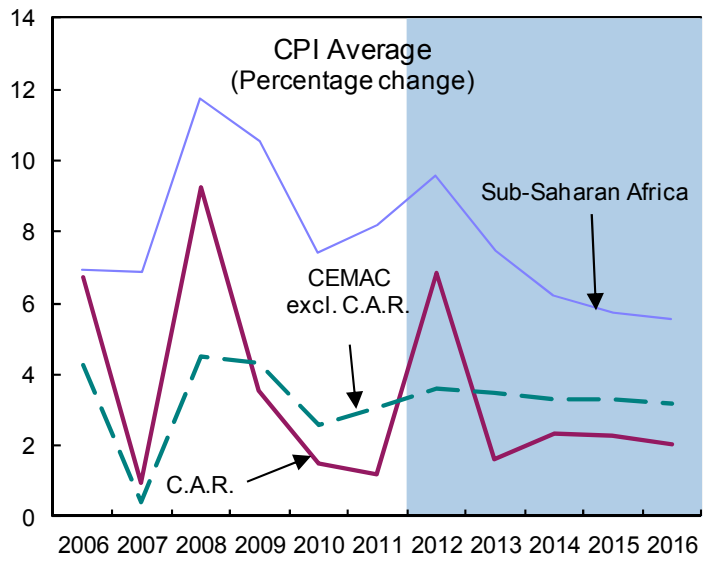

...allowing for a modest increase in capital expenditure.

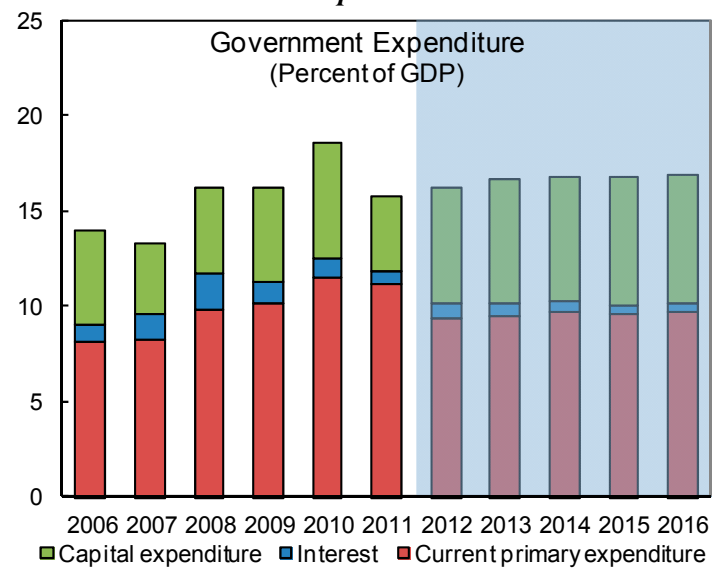

... as would the external position, leading to a buildup of international reserves.

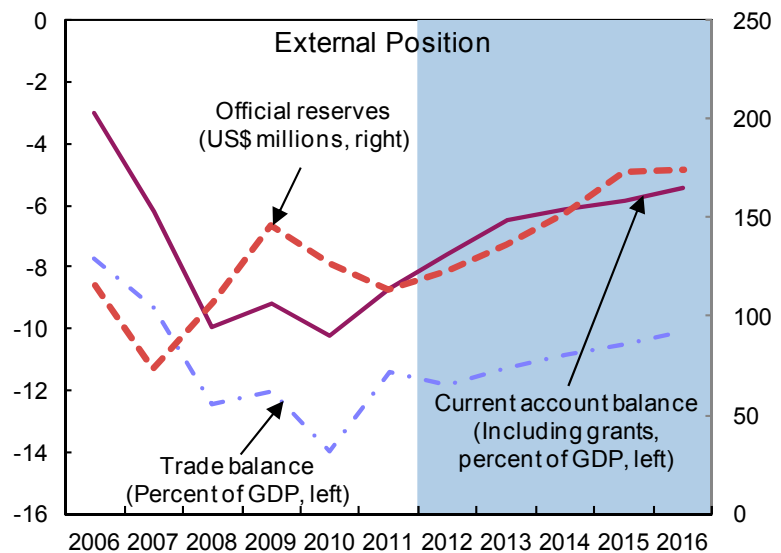




\section{B. Medium-Term Structural Policies}

11. The authorities' medium-term fiscal program is consistent with long-term debt sustainability. The fiscal program aims at generating modest domestic primary surpluses and putting the public debt on a downward trend as the government accelerates the clearance of domestic payment arrears and relies mostly on grant financing. It focuses on renewed efforts at domestic revenue mobilization to raise 1.4 percentage points of GDP in additional revenue by 2014 . The authorities therefore plan a comprehensive tax policy reform and reorganization of the tax and customs administrations based on TA recommendations from the IMF and the EU (MEFP -13). Measures are also being implemented to reestablish expenditure and payments discipline and reorient expenditure. The key objective is to create fiscal space to allow for some increase in investment and poverty-reduction spending while facilitating the clearance of domestic payment arrears. ${ }^{4}$

\section{PFM will be strengthened to put in place a medium-term expenditure}

framework by 2014 (Box 3). The government's reform priorities are based on the findings of diagnostic TA missions by the IMF, the EU, and the World Bank. The priorities are to (i) strengthen liquidity management; (ii) improve expenditure tracking and budget monitoring; (iii) enhance debt management; and (iv) increase fiscal transparency.

13. Reforms will also be undertaken to build human and institutional capacity. The program aims at strengthening administrative capacity and institutions in all areas of public sector management, including debt management; project implementation to enhance resource absorption, sustain growth, and improve program implementation (MEFP $\mid 21-23$ ). The policies being pursued are geared at leveraging TA resources to maximize synergies and increase the effectiveness of TA and capacity building.

14. Donor coordination is being enhanced. Representatives of key donors in the field have set up a General Framework for Budget Support to help improve the predictability of aid, facilitate its administration, and coordinate their technical assistance programs, particularly in the PFM area. The EU is making available $€ 5$ million for PFM and the AfDB approved an SDR 4.5 million grant also in support of PFM. France has posted two resident fiscal advisors. The IMF is taking the lead in the provision of TA for revenue mobilization. The representatives meet regularly to share information on their respective TA programs to avoid duplication.

\footnotetext{
${ }^{4}$ In 2012, clearance of these arrears is set at CFAF 4 billion (0.4 percent of GDP) to be raised by one-half of higher-than-programmed grants.
} 


\section{Box 3. Strengthening Public Financial Management}

The public expenditure and financial accountability assessment (PEFA) conducted in 2010 pointed to the need to increase the credibility of the budget and further improve its transparency. IMF Fiscal Affairs department TA missions in 2009 and 2012 recommended that reforms be geared toward (i) strengthening liquidity management; (ii) improving expenditure tracking and budget monitoring; (iii) enhancing debt management; and (iv) clearing domestic payments arrears because these undermine confidence in the budget process. Indeed, suppliers often require prepayment for services, creating pressures to resort to exemptions from standard spending procedures.

Against this backdrop, the authorities have adopted a long-term strategy that seeks to

- $\quad$ limit the use of exceptional payment procedures to no more than 5 percent of current nonwage, noninterest domestically financed expenditure;

- $\quad$ ensure ownership and reliability of the budget execution monitoring software (GESCO);

- $\quad$ conduct a comprehensive inventory of arrears and draw up a strategy, based on clear, objective and transparent criteria, to clear arrears accumulated up to December 31, 2011, particularly commercial arrears;

- $\quad$ adopt a substantive capacity building program, supported by appropriate human capital development and retention policies;

- $\quad$ implement the cash-flow management mechanism efficiently, with a cash-flow management plan that is constantly updated and strictly implemented to prevent the accumulation of new arrears;

- $\quad$ ensure the dissemination and use of procedure manuals, adequate staff training, and proper keeping of the accounts used to generate reliable and accurate quarterly statements on the $20^{\text {th }}$ day of the month after the end of every quarter; and

- $\quad$ strengthen the capacity and increase the means at the disposal of three key institutions: the Finance Auditor Office, State Auditor Office, and Court of Auditors.

Measures implemented in the early stages will seek to gradually prepare agencies and institutions for more complex reforms in the medium and long terms and culminate in the adoption of a Medium-Term Expenditure Framework. 


\section{The Program FOR 2012-13}

15. Fiscal consolidation is the key priority. This is to be achieved through revenueraising and expenditure-reducing measures to generate a domestic primary surplus of 0.6 percent of GDP (MEFP $\uparrow 18$ ). It also is vital to strengthen budget execution to restore donor confidence and support the growth and stability objectives (Box 4).

\section{A. Fiscal Policy}

16. Expenditure reduction will bear the brunt of the fiscal adjustment. This has become necessary given the rapid increase in nonessential current expenditure in 2010-11. Thus, the objectives include: (i) achieving fiscal consolidation through the reduction of current expenditure and a modest increase in fiscal revenue; (ii) strengthening budget execution and more generally PFM through a thorough and transparent accounting of transactions and streamlining of the expenditure chain (MEFP 914 ); and (iii) normalizing relations with external creditors (MEFP 96 ). To achieve the increase in fiscal revenue, the authorities have committed to adjusting domestic petroleum prices monthly to ensure full pass-through to, at a minimum, eliminate subsidies on consumption ( $\{3$ and MEFP $\uparrow 19$ ).

\section{Specific actions for strengthening budget execution include}

- $\quad$ Preparation of monthly cash-flow plans based on the fiscal targets under the 2012-13 program (prior action) and current-year approved budgets thereafter (structural benchmark) (MEFP $\mid 20)$.

- $\quad$ Further improvement of the expenditure management process, through relieving identified capacity constraints and strengthening (i) cash-flow management; (ii) budget execution and public accounting; and (iii) computerization of expenditure procedures, drawing on the recommendations of IMF TA missions, and on the findings of diagnostic TA missions from the EU, the AfDB, and the World Bank (MEFP $q 14)$. 


\section{Box 4. Improving Confidence in the Budget Process}

Following the fiscal slippages in 2010-2011 that raised governance concerns, the government made strengthening budget execution the lynchpin of the fiscal program in 2012. It has revitalized two existing liquidity monitoring units and created a budget management monitoring committee.

The Liquidity Monitoring Commission (CSL), chaired by the Minister of Finance and Budget, meets monthly, draws up annual and monthly cash-flow plans, and assesses the conditions for their implementation. The CSL receives the proposals of the Technical Unit on Liquidity Monitoring (CTSL) and considers reports on budget execution from the Budget Management Monitoring Committee (CSGB).

The newly established CSGB meets biweekly and sets ceilings for spending based on the cashflow plans adopted by the CSL. The CSGB is chaired by the Director General of the Budget and monitors revenue collection, disbursements and use of external financing support. It ensures that spending is tracked in the budget process, and produces a report on budget execution.

The CTSL is responsible for collecting daily data on revenue, expenditure and financing, and monitors liquidity developments. It also regularly undertakes accounts reconciliation with banks, and produces a weekly report on the cash-flow and the execution of cash-flow plans that is transmitted to the CSL and the CSGB.

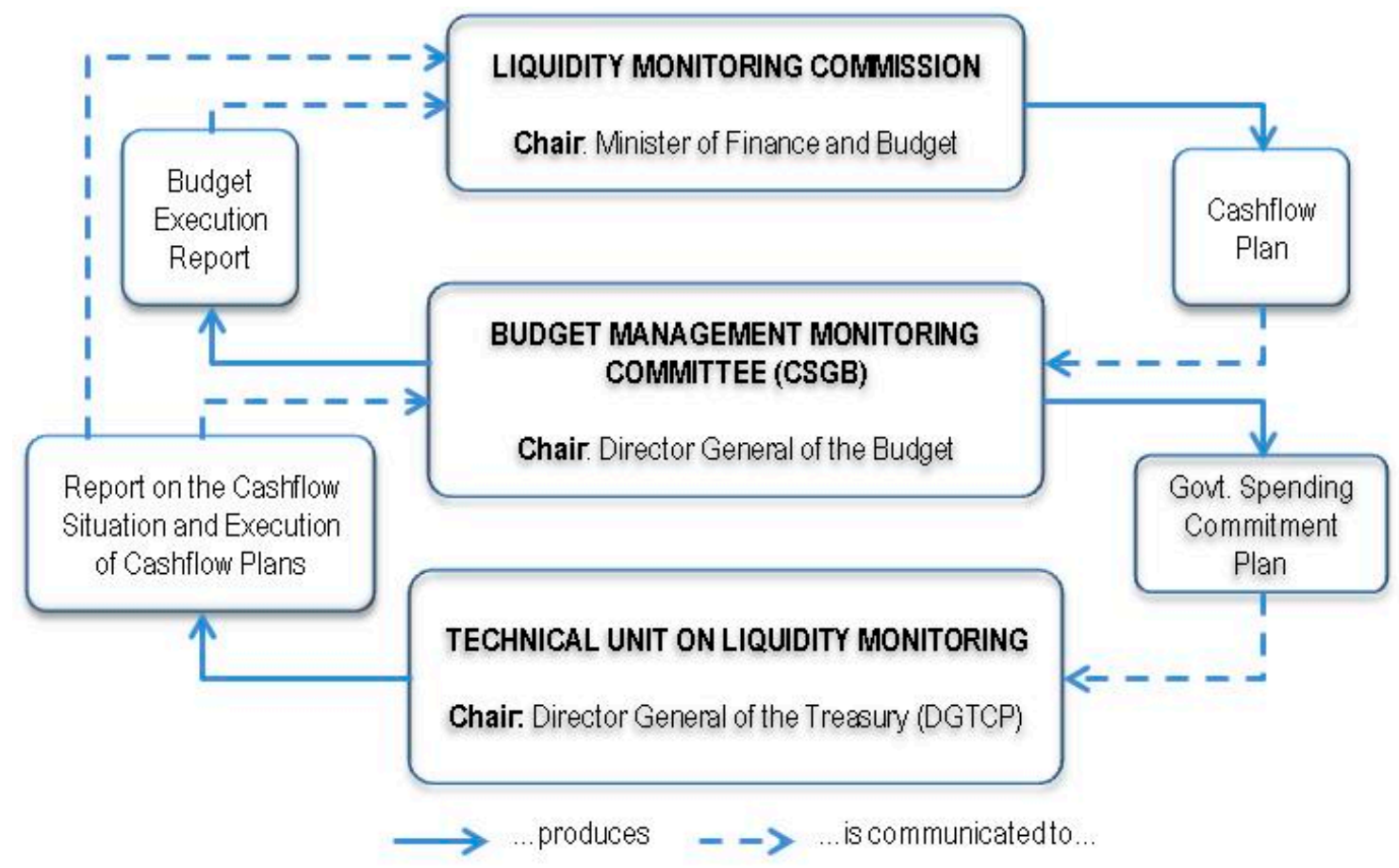




\section{B. Structural Reforms}

18. Structural reforms aimed at promoting inclusive growth are critical for transitioning out of fragility. Inclusive growth over an extended period is critical for poverty reduction and progress toward the MDGs. Inasmuch as inclusiveness encompasses equity and equality of opportunity - in terms of access to markets, resources, and an unbiased regulatory environment for businesses and individuals - the policies should be geared toward a longer-term perspective, focusing on productive employment. The authorities intend to (i) develop and implement with the assistance of key donors, including the International Labor Organization, a growth strategy that is anchored on improving productivity and creating new employment opportunities; (ii) accelerate the implementation of reforms aimed at creating a business-friendly environment, in particular by strengthening the judiciary and the regulatory framework, simplifying land registry and promoting access to financing (MEFP \15).

19. Financial intermediation remains shallow but financial soundness indicators are broadly satisfactory. However, nonperforming loans rose in 2011 amid lower provisioning, but commercial banks continued to be well capitalized and prudential ratios remain, by and large, adequate. Restructuring of the intervened bank (Commercial Bank - CentrafriqueCBCA) and the government's planned divestiture from its capital (MEFP q26) will help foster competition and create an environment conducive to banks' extending longer-term financing that would help spur growth.

\section{Preserving debt sustainability is important for C.A.R.'s growth and stability} objectives. The updated debt sustainability analysis (DSA) indicates that C.A.R. is at a moderate risk of debt distress (Tables II.1 and II.2 and Figures II.1 and II.2), calling for continued prudent fiscal and borrowing policies. New external debt will therefore need to be largely on concessional terms to preserve debt sustainability. There is also a need to strengthen public debt management, and for the time being, a zero ceiling will be set on nonconcessional borrowing (MEFP $\mid 25$ ). The ceiling could be reconsidered, at the time of program reviews, for specific, well-defined projects, on the basis of assessments by the World Bank and the AfDB and subject to improvements in the debt management as the National Committee on Public Debt (CNDP) becomes operational.

\section{Program Conditionality, Monitoring, ACCess, Financing Assurances, And RISKS}

\section{A. Conditionality and Monitoring}

\section{Conditionality has been tailored to C.A.R.'s weak implementation capacity. In} particular, structural conditionality has been streamlined and the performance criteria (PCs) simplified. Implementation of the program will be monitored biannually based on quantitative PCs set for end-June 2012 and end-December 2012, as well as indicative targets 
(ITs) set for end-September 2012 and end-March 2013 (Table I.1). ${ }^{5}$ Structural benchmarks (SBs), as described in Table I.2, will also be used to monitor progress.

\section{B. Access and Capacity to Repay the IMF}

22. The proposed access is consistent with the access policy norm. At 75 percent of quota (SDR 41.775 million) it also strikes the right balance between adjustment and financing and the protracted balance of payments needs. Staff proposes frontloading the firstyear of the arrangement (37.5 percent of quota) ${ }^{6}$ to provide the needed flexibility to cope with any negative spillovers from the uncertain global environment (Table 6). C.A.R.'s capacity to repay the IMF is adequate given the low level of outstanding debt to the IMF (Table 7). The major mining project underway is expected to strengthen C.A.R.'s capacity to repay the IMF.

\section{Financing Assurances}

23. The first year of the ECF-supported program is fully financed. At a coordination meeting in February following conclusion of the Article IV consultation, the AfDB, the EU, and the World Bank indicated their readiness to resume budget support, which helped close the financing gap in 2012. The government is pursuing discussions with official bilateral creditors to secure debt relief on terms comparable to the agreement reached with Paris Club creditors at the completion point under the HIPC Initiative. It is also making good faith efforts to reach collaborative agreements with its external private creditors.

\section{Risks and Mitigation}

\section{The main risk to the program arises from the fragile political and security} situation. The completion of the general elections in 2011 and the Inclusive Political Dialogue (MEFP I1) coupled with the relaunch of the DDR process have contributed to reducing this risks, but the situation remains fragile, particularly in light of the presence in the country of foreign rebel groups. On the economic front, should the increase in world oil prices be sustained, the authorities' resolve to ensure a pass-through of these increases to domestic petroleum prices could be tested. However, adoption of targeted measures to protect the most vulnerable groups of the population (MEFP 919 ) would mitigate this risk. More generally, the prior actions implemented have reduced risks to the program.

\footnotetext{
${ }^{5}$ The increase of social sector spending will be monitored through quarterly floors set on the spending of four key ministries, as ITs.

${ }^{6}$ To be disbursed in three installments equal to SDR 6.963 million each (12.5 percent of quota), at the time of program approval and the first and second reviews.
} 


\section{E. Data Issues}

25. Data provided by the authorities are broadly adequate for program monitoring. Despite some weaknesses, data provision is sufficient for program monitoring, although emphasis should be given on timely reporting of information specified in the Technical Memorandum of Understanding (Table I.3).

\section{Staff Appraisal}

26. C.A.R.'s economic growth has been gaining momentum and medium-term prospects are improving. The positive growth prospects in 2012 and beyond are predicated on increased FDI in the mining sector and strong recovery in agriculture. The coming onstream of a major mining project and ongoing oil exploration are expected to continue driving growth in the medium term. It is important that efforts to improve the security situation be pursued. Also, concrete progress in improving the business climate and developing basic infrastructure will be crucial in ensuring that potential investments in the mining sector are realized.

27. The proposed fiscal stance strikes a balance between fiscal consolidation and the need for spending on priority sectors and infrastructure. Given the fiscal slippages in 2010/11, the program focuses on reducing nonessential expenditure to underpin the necessary fiscal consolidation. Over the medium term, domestic revenue mobilization would create fiscal space, and the authorities need to implement the reforms underway to modernize the tax and customs administrations and enhance their efficiency. In the meantime, the authorities should remain steadfast in the pass-through of world oil prices and implement well-targeted measures to protect the most vulnerable segments of the population.

28. Staff welcomes the reengagement of key donors. The resumption of donor budget support, suspended in 2011, and the concessional resources provided by the IMF will close the financing gap, increase poverty and infrastructure spending, and help C.A.R. progress toward the MDGs.

29. Implementation of structural reforms needs to be accelerated to support to the government's medium-term objectives. In particular, improving the business environment will help attract private sector investment, including FDI in the mining, oil and agricultural sectors. Adoption of a legal framework for large-scale private projects is essential to private investment takeoff. In particular, better dialogue between the authorities and the private sector will create synergies for more and longer-lasting growth.

30. The staff notes the government's commitment to reducing its stake in CBCA. The authorities need to step up efforts to find a strategic partner to take over the government stake in the bank and create the conditions to deepen financial intermediation. 


\section{Strengthening debt management capacity to effectively monitor debt}

development is essential. Staff welcomes the authorities' intention to pursue a prudent debt policy and the measures taken to strengthen debt management capacity. The authorities now need to adopt the relevant texts to make the CNDP operational. They are encouraged to pursue negotiations with non-Paris Club creditors to reach agreements consistent with the enhanced HIPC-Initiative framework and on comparable terms to those granted by the Paris Club.

32. Staff supports the authorities' request for a three-year arrangement under the ECF. The arrangement will help catalyze donors' support to help fight poverty and strengthen administrative capacity and institutions. Staff believes that the risks to the program are mitigated by the prior actions taken to improve fiscal management and safeguard the revenue target and the efforts to revitalize the DDR process and improve security. 
Figure 3. Central African Republic: Recent Economic Performance, 2003-11

Growth has been very modest...

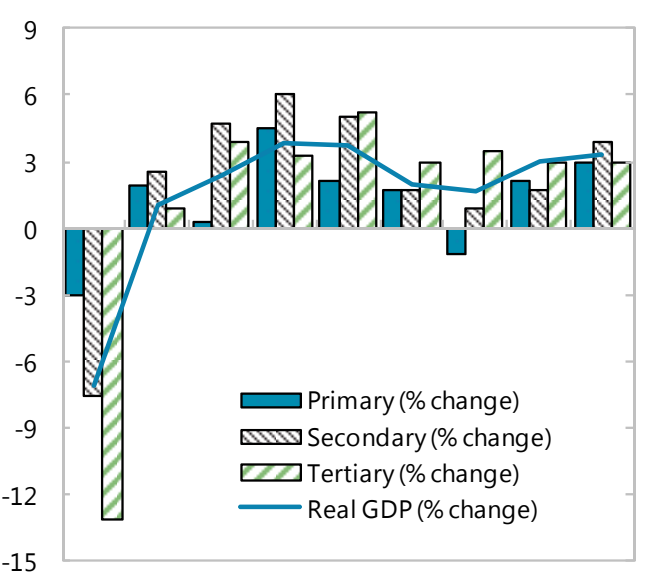

200320042005200620072008200920102011 ...keeping C.A.R. one of the poorest countries, even compared to other fragile states.

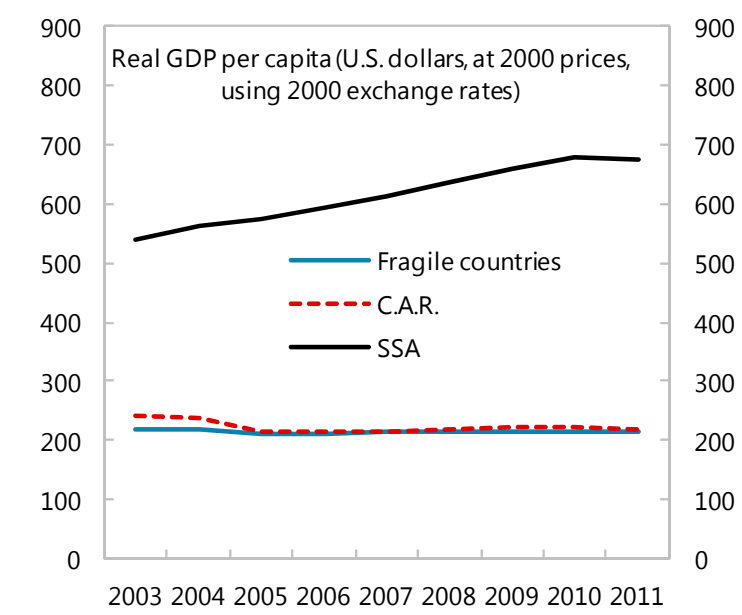

Despite a surge in inflation at end-2011, driven by food prices...

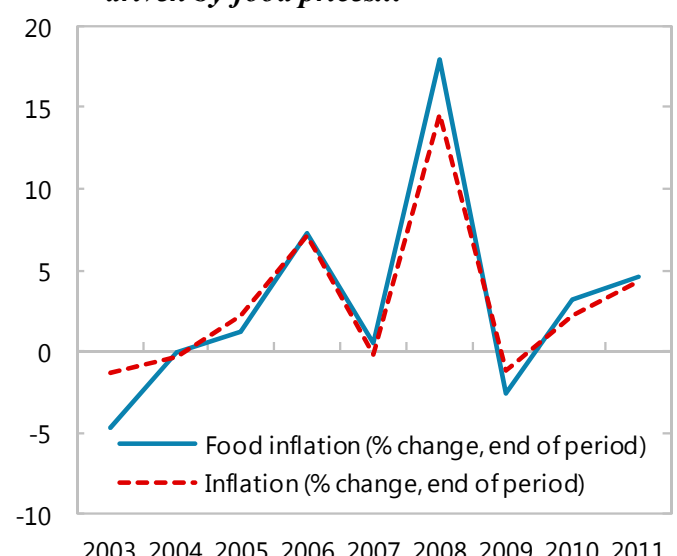

200320042005200620072008200920102011

As public investment collapsed ...

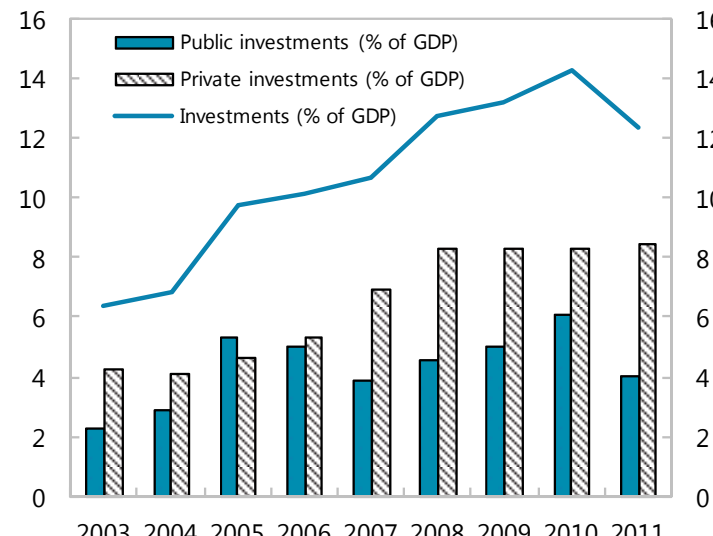

200320042005200620072008200920102011

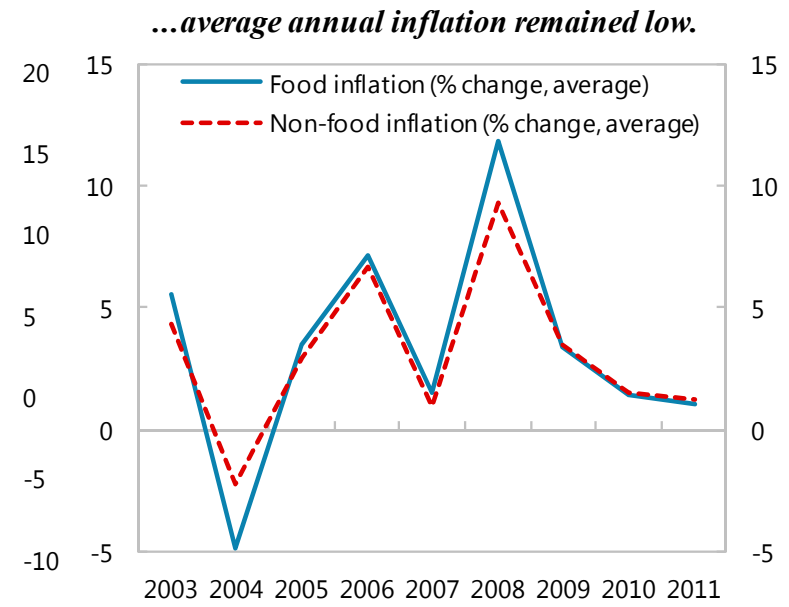

200320042005200620072008200920102011

...the savings and investment imbalance

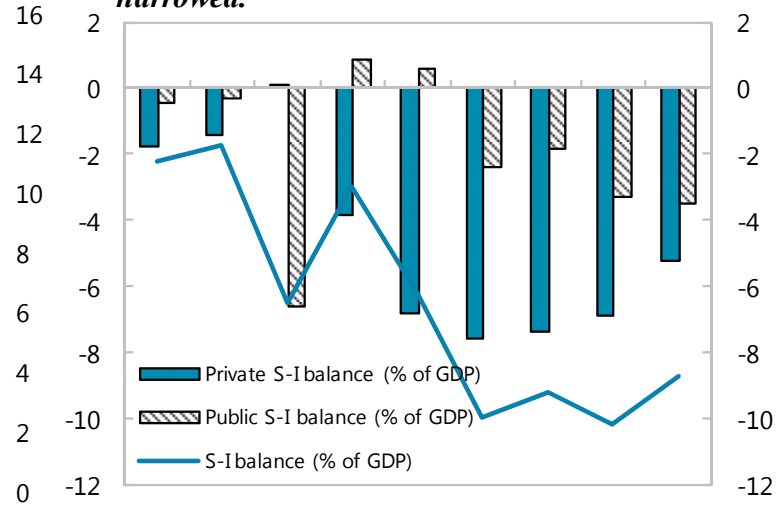

200320042005200620072008200920102011 narrowed.

Sources: C.A.R. authorities; and IMF staff estimates. 
Figure 4. Central African Republic: Fiscal Developments, 2003-11

With a sharp decline in grants and reduced domestic revenue, in 2011,...

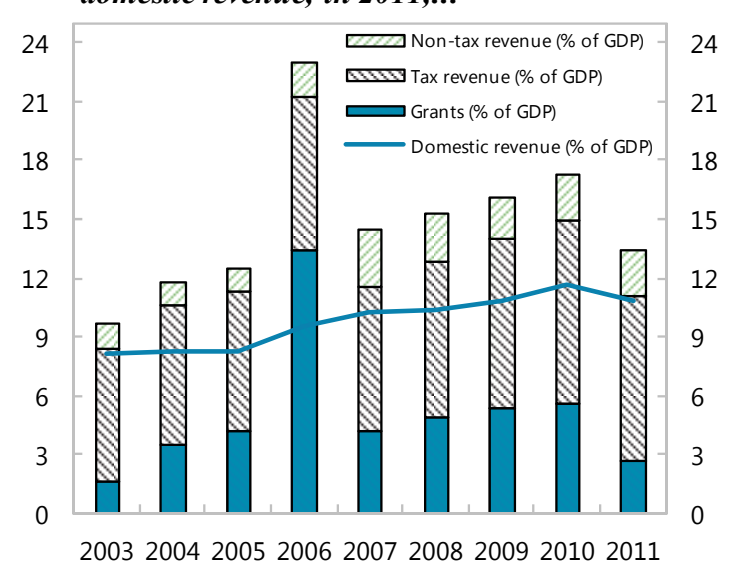

...current expenditure returned to more sustainable levels; and public investment dropped sharply...

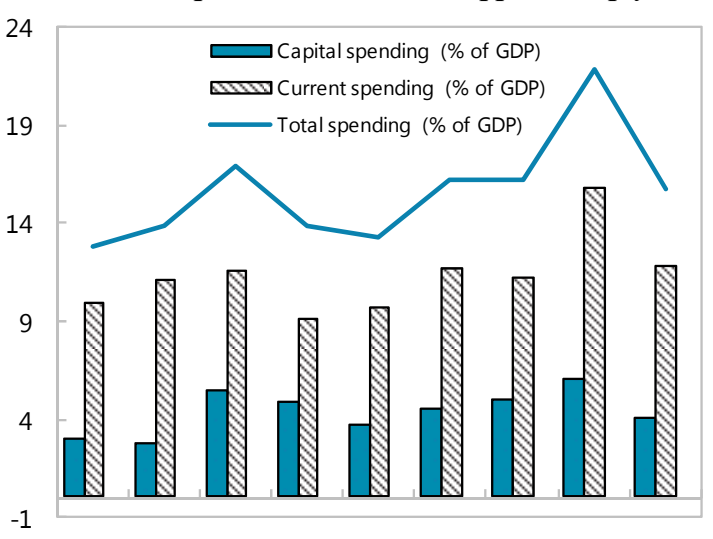

200320042005200620072008200920102011 ...driven by a contraction in consumption tax collection,...

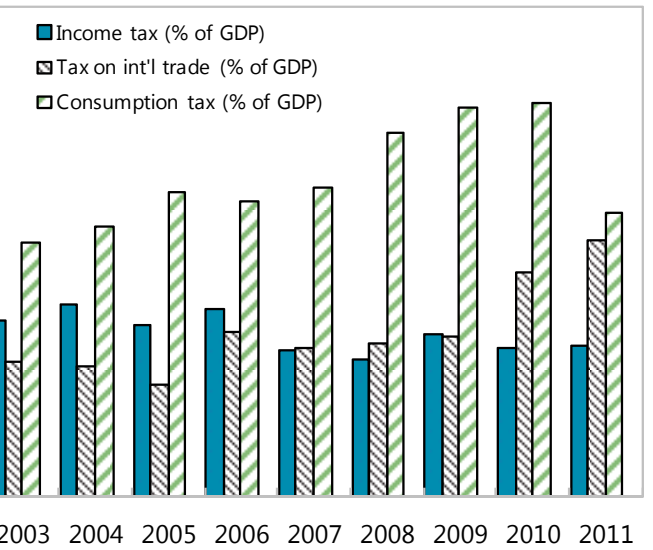

... with a deterioration in the fiscal position in 2011...

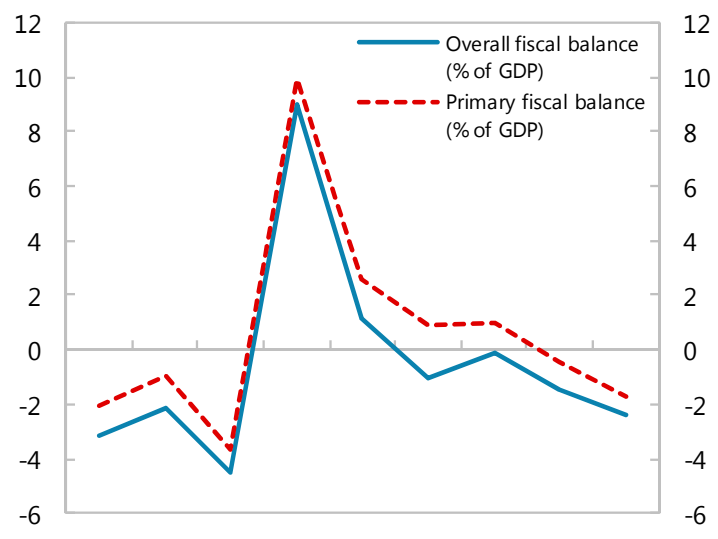

200320042005200620072008200920102011

...resulting in a modest buildup of public debt.

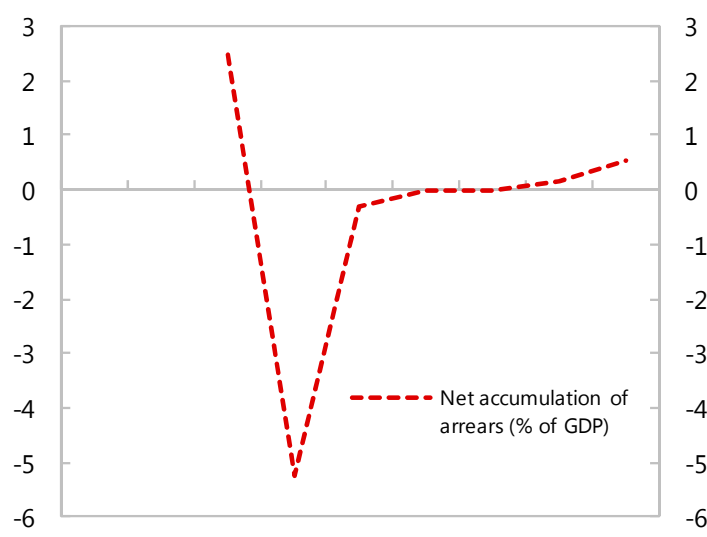

200320042005200620072008200920102011

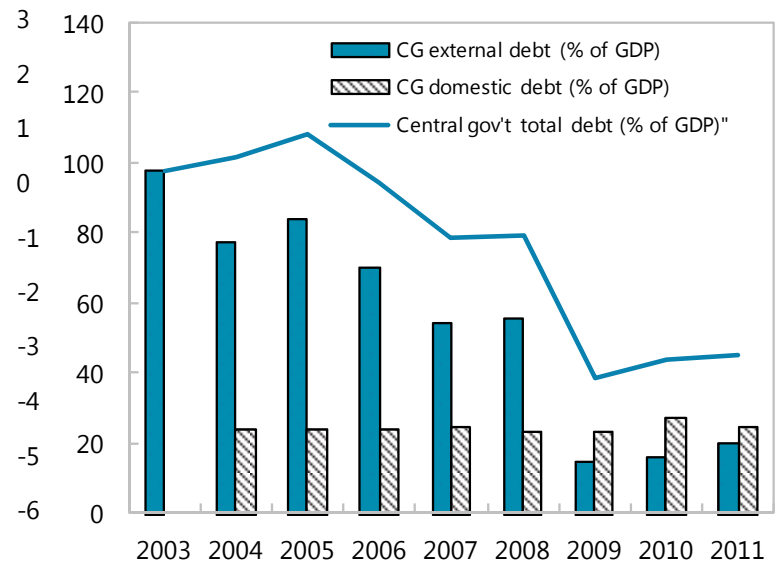

Sources: C.A.R. authorities; and IMF staff estimates. 
Figure 5. Central African Republic: Monetary Developments, 2003-11

Overall, money supply remained under control, with velocity of broad money relatively stable and net domestic assets increasing in line with stepped-up credit to the private sector.
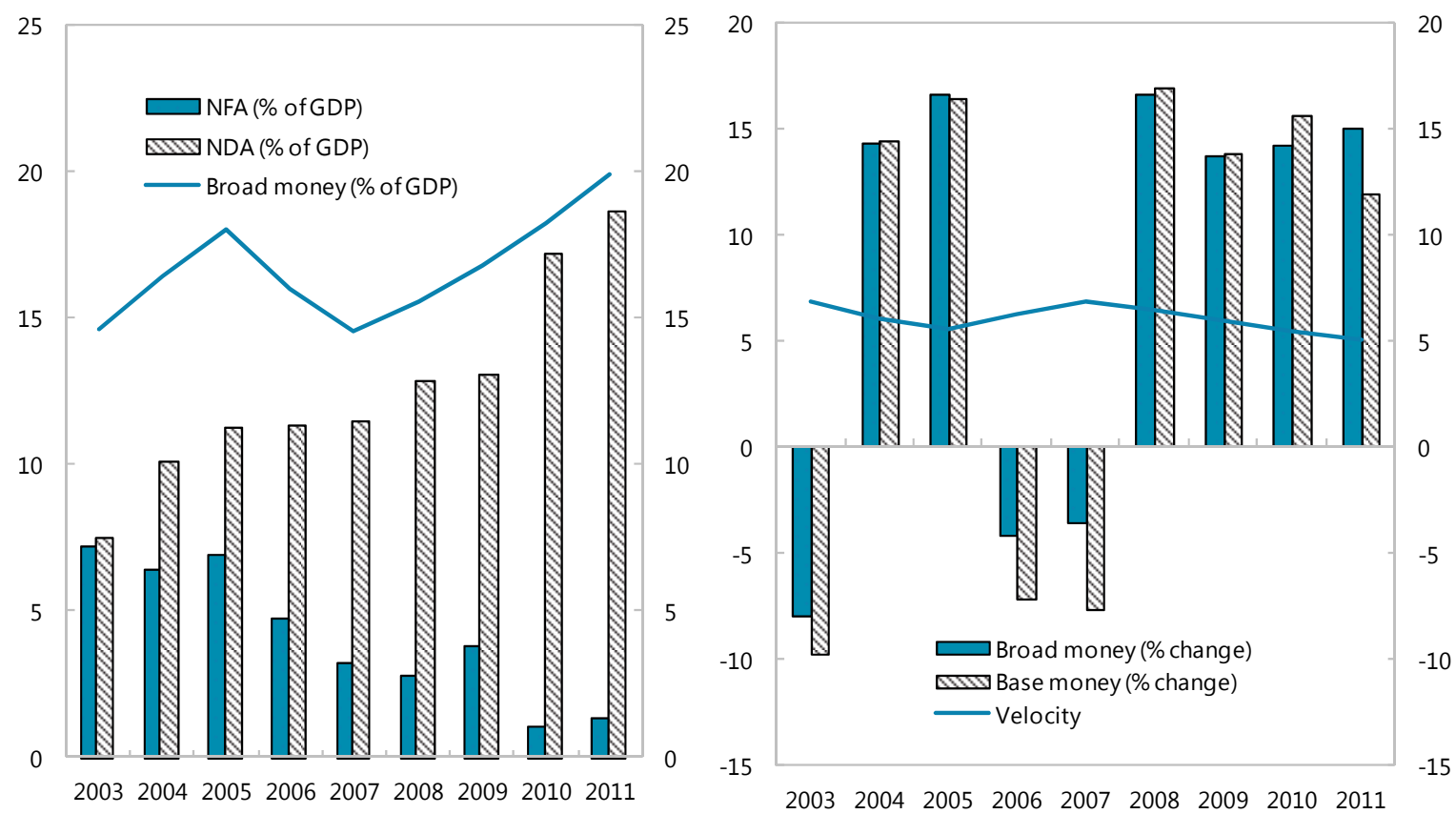

Credit to the private sector has been growing relative to $G D P, \ldots$

....and NPLs trended down steadily though they rose slightly in 2011.

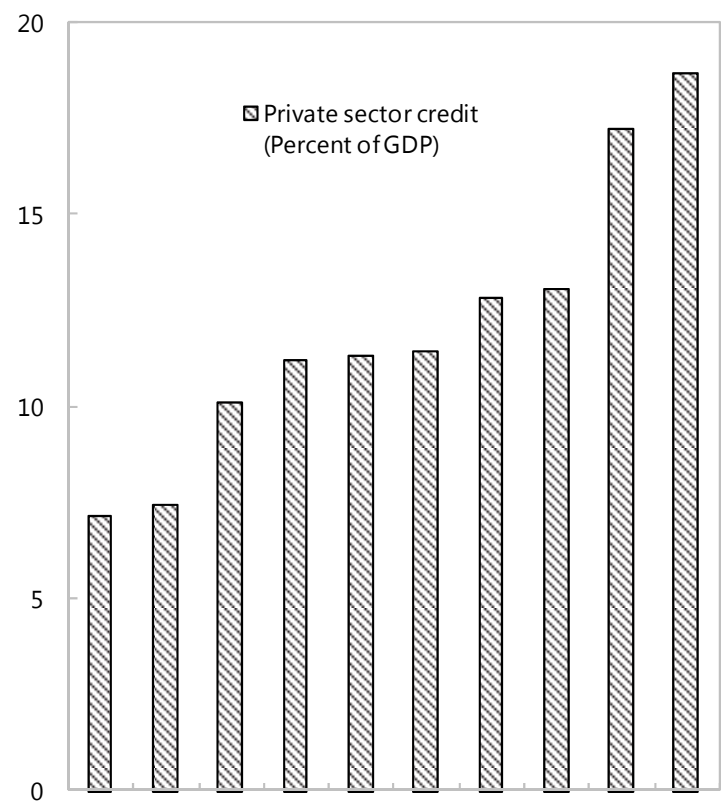

2002200320042005200620072008200920102011

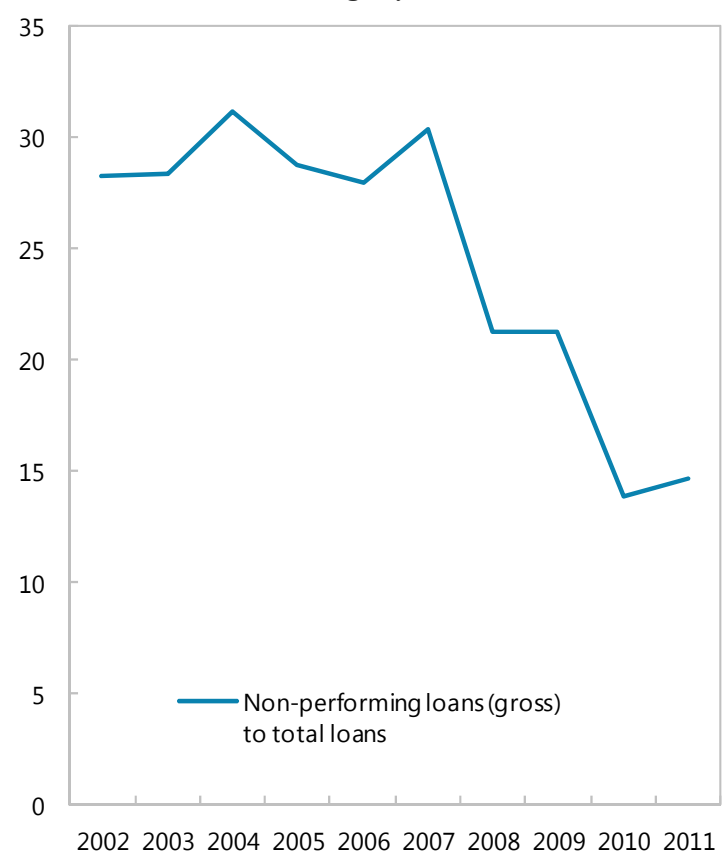

Sources: C.A.R. authorities; and IMF staff estimates. 
Figure 6. Central African Republic: External Developments, 2003-11

$A$ recovery in the exports of diamonds, gold, and timber led by better international prices in 2011...

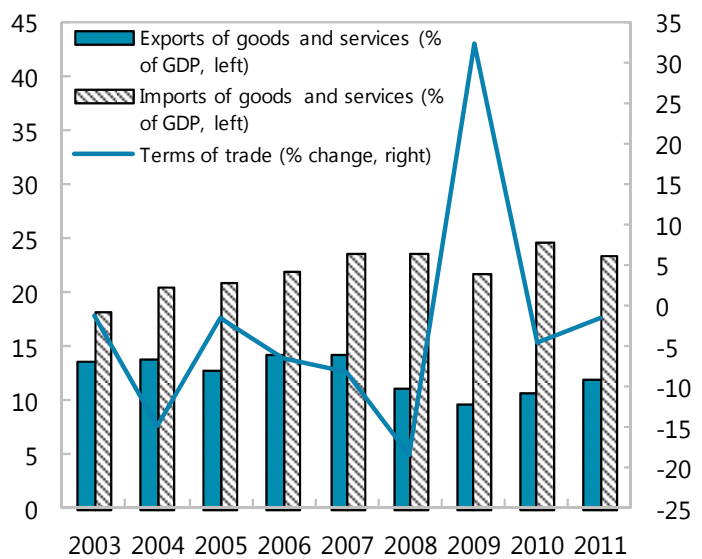

200320042005200620072008200920102011
... helped to narrow the current account deficit.

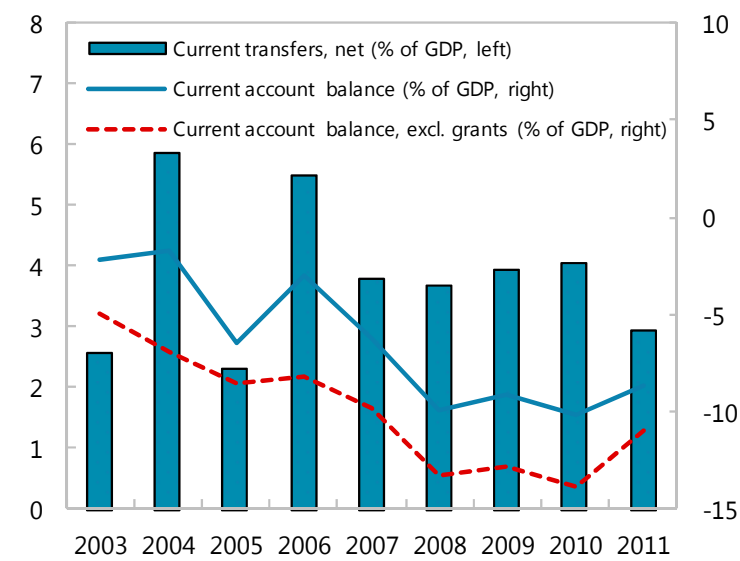

... leading to a decline in reserves coverage.

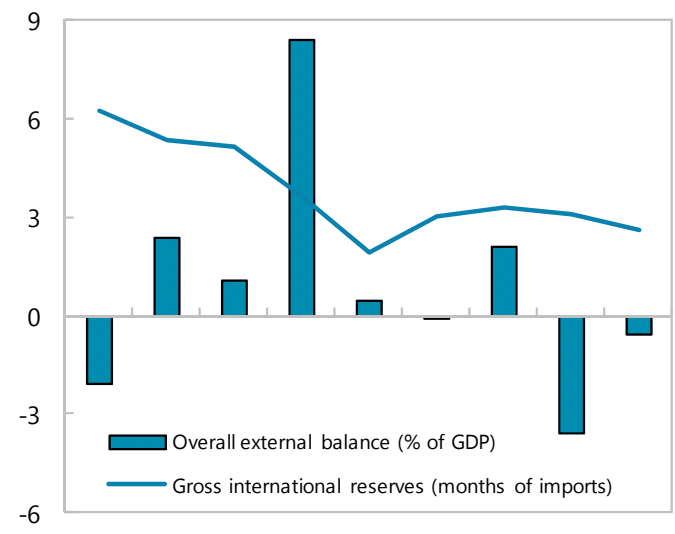

200320042005200620072008200920102011

... despite the appreciation of the CFA franc against the US dollar.

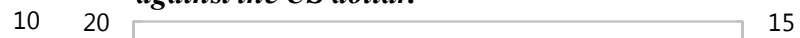

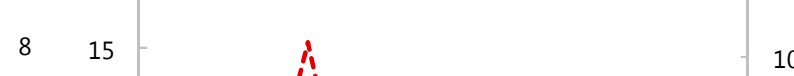

$6 \begin{array}{ll}8 & 15 \\ 6 & 10\end{array}$

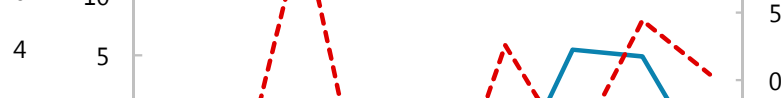

2

2

$0-5$

$-2-10$

$-4 \quad-15$

$-20$

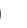

$-5$ 


\begin{tabular}{|c|c|c|c|c|c|c|c|}
\hline & 2009 & 2010 & $\begin{array}{l}2011 \\
\text { Prel. }\end{array}$ & $\begin{array}{c}2012 \\
\text { Prog. } \\
\end{array}$ & $\begin{array}{c}2013 \\
\text { Prog. }\end{array}$ & $\begin{array}{c}2014 \\
\text { Prog. }\end{array}$ & $\begin{array}{l}2015 \\
\text { Prog. }\end{array}$ \\
\hline & \multicolumn{7}{|c|}{ (Annual percentage change; unless otherwise indicated) } \\
\hline National income and prices & & & & & & & \\
\hline GDP at constant prices & 1.7 & 3.0 & 3.3 & 4.1 & 4.2 & 5.9 & 5.2 \\
\hline GDP at current prices & 5.4 & 5.1 & 5.3 & 8.4 & 6.3 & 8.6 & 8.1 \\
\hline GDP deflator & 3.6 & 2.1 & 1.1 & 4.2 & 2.0 & 2.6 & 2.8 \\
\hline CPI (annual average) & 3.5 & 1.5 & 1.2 & 6.8 & 1.6 & 2.3 & 2.3 \\
\hline CPI (end-of-period) & -1.2 & 2.3 & 4.3 & 2.9 & 2.3 & 2.3 & 2.3 \\
\hline \multicolumn{8}{|l|}{ Central government finance } \\
\hline Total revenue and grants & 11.5 & 12.3 & -18.2 & 31.9 & 12.4 & 10.7 & 12.1 \\
\hline Total expenditure & 5.4 & 20.7 & -6.4 & 6.5 & 9.0 & 9.4 & 7.9 \\
\hline \multicolumn{8}{|l|}{ Money and credit } \\
\hline Net domestic assets ${ }^{1}$ & 6.1 & 30.1 & 13.2 & 9.9 & 3.7 & 5.6 & 7.4 \\
\hline Domestic credit ${ }^{1}$ & 9.5 & 29.1 & 21.7 & 7.3 & 3.7 & 5.6 & 10.5 \\
\hline Broad money & 13.7 & 14.2 & 15.0 & 13.8 & 2.6 & 7.7 & 4.2 \\
\hline Velocity of broad money (end-of-period) & 6.0 & 5.5 & 5.0 & 5.0 & 5.0 & 5.0 & 5.2 \\
\hline \multicolumn{8}{|l|}{ External sector } \\
\hline Exports, f.o.b. (US $\$$ basis) & -17.6 & 13.7 & 32.3 & 7.0 & 5.6 & 5.1 & 8.2 \\
\hline Export volume of goods & -21.9 & 9.7 & 5.1 & 11.6 & 4.9 & 4.2 & 9.5 \\
\hline Imports, f.o.b. (US\$ basis) & -9.7 & 12.6 & 4.8 & 8.0 & 6.8 & 7.1 & 8.1 \\
\hline Import volume of goods & 13.3 & 3.6 & -17.9 & 16.8 & 7.6 & 8.4 & 5.0 \\
\hline Terms of trade & 32.4 & -4.6 & -1.4 & 3.6 & 1.5 & 2.0 & -4.0 \\
\hline Nominal effective exchange rate & -0.8 & -4.2 & 0.8 & $\ldots$ & $\ldots$ & $\ldots$ & $\ldots$ \\
\hline \multirow[t]{2}{*}{ Real effective exchange rate } & 2.0 & -4.7 & -1.1 & $\ldots$ & $\ldots$ & $\ldots$ & $\ldots$ \\
\hline & \multicolumn{7}{|c|}{ (Percent of GDP; unless otherwise indicated) } \\
\hline Gross national savings & 4.0 & 4.1 & 3.6 & 7.3 & 9.3 & 10.1 & 11.1 \\
\hline Of which: current official transfers & 1.7 & 1.4 & 0.0 & 1.0 & 1.6 & 1.6 & 1.6 \\
\hline Gross domestic savings & 1.2 & 0.3 & 1.0 & 3.1 & 4.5 & 5.3 & 6.4 \\
\hline Government & 0.0 & -0.7 & -1.5 & 1.4 & 1.6 & 2.0 & 2.9 \\
\hline Private sector & 1.2 & 1.0 & 2.5 & 1.7 & 2.8 & 3.3 & 3.5 \\
\hline Consumption & 98.8 & 99.7 & 99.0 & 96.9 & 95.5 & 94.7 & 93.6 \\
\hline Government & 7.5 & 8.2 & 7.9 & 7.3 & 7.3 & 7.4 & 7.5 \\
\hline Private sector & 91.4 & 91.5 & 91.1 & 89.6 & 88.2 & 87.3 & 86.1 \\
\hline Gross investment & 13.2 & 14.3 & 12.4 & 14.9 & 15.7 & 16.2 & 16.9 \\
\hline Government & 4.9 & 6.0 & 4.0 & 6.1 & 6.5 & 6.5 & 6.7 \\
\hline Private sector & 8.2 & 8.2 & 8.4 & 8.8 & 9.3 & 9.7 & 10.2 \\
\hline Current transfers and factor income (net) & 2.8 & 3.8 & 2.7 & 4.2 & 4.8 & 4.7 & 4.7 \\
\hline External current account balance & -9.2 & -10.2 & -8.7 & -7.6 & -6.5 & -6.1 & -5.8 \\
\hline Overall balance of payments & 2.1 & -3.6 & -0.6 & 0.3 & 0.5 & 0.4 & 1.1 \\
\hline \multicolumn{8}{|l|}{ Central government finance } \\
\hline Total revenue & 16.1 & 17.2 & 13.3 & 16.2 & 17.1 & 17.5 & 18.1 \\
\hline Total expenditure $^{2}$ & -16.2 & -22.0 & -16.5 & -16.2 & -16.6 & -16.8 & -16.7 \\
\hline \multicolumn{8}{|l|}{ Overall balance $^{2}$} \\
\hline Excluding grants & -5.4 & -1.0 & -4.9 & -4.8 & -4.9 & -4.5 & -3.9 \\
\hline Including grants & -0.1 & -1.4 & -2.4 & 0.0 & 0.5 & 0.7 & 1.4 \\
\hline Domestic primary balance $^{3}$ & -0.3 & -1.0 & -1.3 & 0.4 & 0.6 & 0.7 & 1.3 \\
\hline Net present value of external public and guaranteed debt & 7.5 & 13.2 & 16.2 & 14.9 & 14.5 & 13.8 & 12.1 \\
\hline Public sector debt & 36.8 & 41.9 & 42.2 & 38.9 & 36.1 & 32.5 & 28.7 \\
\hline Of which: domestic debt ${ }^{4}$ & 23.5 & 24.4 & 25.0 & 23.0 & 20.2 & 16.8 & 13.6 \\
\hline \multicolumn{8}{|l|}{ Gross official foreign reserves } \\
\hline (US\$ millions, end-of-period) & 146.5 & 126.5 & 113.9 & 123.7 & 136.6 & 152.6 & 173.0 \\
\hline (months of imports, f.o.b.) & 3.3 & 3.1 & 2.6 & 2.7 & 2.8 & 3.0 & 3.2 \\
\hline Nominal GDP (CFAF billions) & 936 & 984 & 1,036 & 1,123 & 1,193 & 1,296 & 1,401 \\
\hline Exchange rate (average; CFAF per US $\$$ ) & 472.2 & 495.3 & 471.9 & & $\ldots$ & $\ldots$ & \\
\hline \multicolumn{8}{|c|}{$\begin{array}{l}\text { Sources: C.A.R. authorities; and IMF staff estimates and projections. } \\
{ }^{1} \text { Percent of broad money at beginning of the period. } \\
{ }^{2} \text { Expenditure is on a cash basis for current period expenditure. } \\
{ }^{3} \text { Excludes grants, interest payments, and externally financed capital expenditure. } \\
{ }^{4} \text { Comprises government debt to BEAC and commercial banks, government arrears, and public enterprises' domestic debt. }\end{array}$} \\
\hline
\end{tabular}




\begin{tabular}{|c|c|c|c|c|c|c|c|}
\hline \multicolumn{8}{|c|}{$\begin{array}{l}\text { Table 2. Central African Republic: Central Government Financial Operations, 2009-15 } \\
\text { (CFAF billions) }\end{array}$} \\
\hline & 2009 & 2010 & $\begin{array}{l}2011 \\
\text { Prel. }\end{array}$ & $\begin{array}{l}2012 \\
\text { Prog. }\end{array}$ & $\begin{array}{l}2013 \\
\text { Prog. }\end{array}$ & $\begin{array}{l}2014 \\
\text { Prog. }\end{array}$ & $\begin{array}{l}2015 \\
\text { Prog. }\end{array}$ \\
\hline Revenue & 150.3 & 168.7 & 138.1 & 182.1 & 204.6 & 226.4 & 254.0 \\
\hline Domestic revenue & 100.8 & 114.2 & 111.8 & 128.1 & 139.8 & 158.2 & 179.9 \\
\hline Tax revenue & 81.1 & 91.9 & 87.1 & 110.0 & 122.1 & 138.6 & 158.8 \\
\hline Taxes on profits and property & 18.4 & 17.8 & 18.8 & 21.4 & 23.7 & 26.8 & 30.5 \\
\hline Taxes on goods and services & 62.7 & 74.2 & 68.3 & 88.6 & 98.4 & 111.8 & 128.3 \\
\hline Of which: international trade & 18.2 & 26.9 & 32.4 & 30.8 & 34.1 & 38.8 & 44.7 \\
\hline Non-tax revenue & 19.8 & 22.3 & 24.7 & 18.1 & 17.6 & 19.6 & 21.1 \\
\hline Grants & 49.4 & 54.5 & 26.3 & 53.9 & 64.8 & 68.2 & 74.0 \\
\hline Program & 16.6 & 13.8 & 0.0 & 11.0 & 18.9 & 20.5 & 22.2 \\
\hline Project & 32.8 & 40.7 & 26.3 & 42.9 & 45.9 & 47.7 & 51.8 \\
\hline Expenditure $^{1}$ & -151.4 & -182.7 & -162.7 & -182.2 & -198.7 & -217.2 & -241.2 \\
\hline Current primary expenditure & -94.5 & -113.3 & -114.6 & -105.1 & -113.3 & -125.7 & -136.4 \\
\hline Wages and salaries & -42.1 & -43.3 & -46.0 & -50.8 & -54.0 & -58.7 & -63.4 \\
\hline Transfers and subsidies ${ }^{2}$ & -24.7 & -32.3 & -32.5 & -23.1 & -26.1 & -30.0 & -31.8 \\
\hline Goods and services & -27.7 & -37.6 & -36.1 & -31.2 & -33.1 & -37.0 & -41.2 \\
\hline Interest due & -10.5 & -9.9 & -7.0 & -8.9 & -8.1 & -7.6 & -6.7 \\
\hline External & -4.1 & -2.0 & -2.7 & -1.3 & -1.0 & -0.8 & -0.4 \\
\hline Domestic & -6.4 & -7.9 & -4.3 & -7.6 & -7.1 & -6.9 & -6.3 \\
\hline Capital expenditure & -46.3 & -59.5 & -41.1 & -68.1 & -77.3 & -83.9 & -98.1 \\
\hline Domestically financed & -9.2 & -11.1 & -10.7 & -16.7 & -19.4 & -23.3 & -28.3 \\
\hline Externally financed & -37.0 & -48.4 & -30.3 & -51.4 & -57.8 & -60.7 & -69.8 \\
\hline \multicolumn{8}{|l|}{ Overall balance } \\
\hline Excluding grants & -50.5 & -68.5 & -50.9 & -54.1 & -58.9 & -59.0 & -61.3 \\
\hline Of which: domestic primary balance ${ }^{3}$ & -3.0 & -10.2 & -13.6 & 6.3 & 7.1 & 9.3 & 15.2 \\
\hline Including grants & -1.1 & -14.0 & -24.6 & -0.1 & 5.9 & 9.2 & 12.7 \\
\hline Net change in arrears $((-)=$ reduction $)$ & -4.5 & -6.2 & 8.1 & -5.4 & -20.0 & -20.0 & -20.0 \\
\hline Domestic & -4.5 & -7.5 & 2.4 & -4.0 & -20.0 & -20.0 & -20.0 \\
\hline External & 0.0 & 1.3 & 5.7 & -1.4 & 0.0 & 0.0 & 0.0 \\
\hline Errors and omissions & 0.3 & -10.7 & 0.0 & 0.0 & 0.0 & 0.0 & 0.0 \\
\hline Overall balance, cash basis & -5.3 & -30.8 & -15.0 & -5.5 & -14.1 & -10.8 & -7.3 \\
\hline Identified financing & 5.3 & 30.8 & 15.1 & 5.4 & 11.7 & 2.7 & 0.7 \\
\hline External, net & 3.7 & 6.4 & -3.9 & 1.1 & 5.3 & 6.3 & 11.5 \\
\hline Project loans & 4.2 & 7.7 & 4.0 & 8.5 & 11.9 & 13.0 & 18.0 \\
\hline Program loans & 0.0 & 0.0 & 0.0 & 0.0 & 0.0 & 0.0 & 0.0 \\
\hline Amortization due & -6.6 & -1.3 & -7.9 & -7.4 & -6.6 & -6.7 & -6.5 \\
\hline Exceptional financing & 6.1 & 0.0 & 0.0 & 0.0 & 0.0 & 0.0 & 0.0 \\
\hline Paris Club ${ }^{4}$ & 0.5 & 0.0 & 0.0 & 0.0 & 0.0 & 0.0 & 0.0 \\
\hline Other ${ }^{5}$ & 5.6 & 0.0 & 0.0 & 0.0 & 0.0 & 0.0 & 0.0 \\
\hline Domestic, net & 1.6 & 24.4 & 19.0 & 4.3 & 6.4 & -3.6 & -10.7 \\
\hline Banking system & 11.1 & 24.1 & 19.4 & 3.5 & 6.4 & -3.6 & -10.7 \\
\hline Counterpart to IMF resources (BEAC) & 6.5 & 6.6 & 1.1 & 10.9 & 8.4 & 5.4 & -3.8 \\
\hline Central Bank & 16.7 & 12.8 & 13.6 & -2.5 & -2.0 & -8.8 & -5.0 \\
\hline Commercial banks & -12.1 & 4.7 & 4.7 & -4.9 & 0.1 & -0.2 & -2.0 \\
\hline Nonbank $^{6}$ & -9.6 & 0.4 & -0.4 & 0.8 & 0.0 & 0.0 & 0.0 \\
\hline Residual financing need & 0.0 & 0.0 & 0.0 & 0.0 & 2.4 & 8.1 & 6.6 \\
\hline \multicolumn{8}{|l|}{ Memorandum items: } \\
\hline Total government debt & 344.3 & 412.1 & 436.9 & 437.0 & 431.1 & 421.9 & 409.2 \\
\hline Government domestic debt & 193.7 & 231.0 & 256.9 & 258.1 & 257.5 & 254.6 & 253.4 \\
\hline Spending for DDR & 0.4 & 1.9 & 2.6 & & $\ldots$ & $\ldots$ & \\
\hline Nominal GDP & 936 & 984 & 1,036 & 1,123 & 1,193 & 1,296 & 1,401 \\
\hline \\
\hline \multicolumn{8}{|c|}{${ }^{1}$ Expenditure is on a cash basis, except for interest, which is recorded on a due basis. } \\
\hline \multicolumn{8}{|c|}{${ }^{2}$ In 2009 and beyond, includes outlays for the disarmament, demobilization and reintegration(DDR) process. } \\
\hline \multicolumn{8}{|c|}{${ }^{3}$ Excludes grants, interest payments, and externally financed capital expenditure. } \\
\hline \multicolumn{8}{|c|}{${ }^{4}$ Reflects Paris Club rescheduling and moratorium agreement in April 2007.} \\
\hline \multicolumn{8}{|c|}{${ }^{5}$ Includes HIPC debt relief from multilateral and other bilateral creditors. For 2008-09, also includes debt service } \\
\hline \multicolumn{8}{|c|}{ to non-Paris Club and commercial creditors. From mid-2009 onward, reflects full delivery of HIPC and MDRI relief on a flow basis. } \\
\hline${ }^{6}$ Includes repayments to CEMAC commercial & domestic & suppliers $\mathrm{f}$ & oil subsid & and on ex & ected futur & bond issu & \\
\hline
\end{tabular}




\begin{tabular}{|c|c|c|c|c|c|c|c|}
\hline \multicolumn{8}{|c|}{$\begin{array}{l}\text { Table 3. Central African Republic: Central Government Financial Operations, 2009-15 } \\
\text { (Percent of GDP) }\end{array}$} \\
\hline & \multirow[t]{2}{*}{2009} & \multirow[t]{2}{*}{2010} & \multirow{2}{*}{$\begin{array}{l}2011 \\
\text { Prel. }\end{array}$} & \multirow{2}{*}{$\begin{array}{l}2012 \\
\text { Prog. }\end{array}$} & \multirow{2}{*}{$\begin{array}{l}2013 \\
\text { Prog. }\end{array}$} & \multirow{2}{*}{$\begin{array}{l}2014 \\
\text { Prog. }\end{array}$} & \multirow{2}{*}{$\begin{array}{l}2015 \\
\text { Prog. }\end{array}$} \\
\hline & & & & & & & \\
\hline Revenue & 16.1 & 17.2 & 13.3 & 16.2 & 17.1 & 17.5 & $\overline{18.1}$ \\
\hline Domestic revenue & 10.8 & 11.6 & 10.8 & 11.4 & 11.7 & 12.2 & 12.8 \\
\hline Tax revenue & 8.7 & 9.3 & 8.4 & 9.8 & 10.2 & 10.7 & 11.3 \\
\hline Taxes on profits and property & 2.0 & 1.8 & 1.8 & 1.9 & 2.0 & 2.1 & 2.2 \\
\hline Taxes on goods and services & 6.7 & 7.5 & 6.6 & 7.9 & 8.2 & 8.6 & 9.2 \\
\hline Of which: taxes on international trade & 1.9 & 2.7 & 3.1 & 2.7 & 2.9 & 3.0 & 3.2 \\
\hline Non-tax revenue & 2.1 & 2.3 & 2.4 & 1.6 & 1.5 & 1.5 & 1.5 \\
\hline Grants & 5.3 & 5.5 & 2.5 & 4.8 & 5.4 & 5.3 & 5.3 \\
\hline Program & 1.8 & 1.4 & 0.0 & 1.0 & 1.6 & 1.6 & 1.6 \\
\hline Project & 3.5 & 4.1 & 2.5 & 3.8 & 3.8 & 3.7 & 3.7 \\
\hline Expenditure $^{1}$ & -16.2 & -18.6 & -15.7 & -16.2 & -16.7 & -16.8 & -17.2 \\
\hline Current primary expenditure & -10.1 & -11.5 & -11.1 & -9.4 & -9.5 & -9.7 & -9.7 \\
\hline Wages and salaries & -4.5 & -4.4 & -4.4 & -4.5 & -4.5 & -4.5 & -4.5 \\
\hline Transfers and subsidies $^{2}$ & -2.6 & -3.3 & -3.1 & -2.1 & -2.2 & -2.3 & -2.3 \\
\hline Goods and services & -3.0 & -3.8 & -3.5 & -2.8 & -2.8 & -2.9 & -2.9 \\
\hline Interest due & -1.1 & -1.0 & -0.7 & -0.8 & -0.7 & -0.6 & -0.5 \\
\hline External & -0.4 & -0.2 & -0.3 & -0.1 & -0.1 & -0.1 & 0.0 \\
\hline Domestic & -0.7 & -0.8 & -0.4 & -0.7 & -0.6 & -0.5 & -0.4 \\
\hline Capital expenditure & -4.9 & -6.0 & -4.0 & -6.1 & -6.5 & -6.5 & -7.0 \\
\hline Domestically financed & -1.0 & -1.1 & -1.0 & -1.5 & -1.6 & -1.8 & -2.0 \\
\hline Externally financed & -4.0 & -4.9 & -2.9 & -4.6 & -4.8 & -4.7 & -5.0 \\
\hline \multicolumn{8}{|l|}{ Overall balance } \\
\hline Excluding grants & -5.4 & -7.0 & -4.9 & -4.8 & -4.9 & -4.6 & -4.4 \\
\hline Of which: domestic primary balance ${ }^{3}$ & -0.3 & -1.0 & -1.3 & 0.6 & 0.6 & 0.7 & 1.1 \\
\hline Including grants & -0.1 & -1.4 & -2.4 & 0.0 & 0.5 & 0.7 & 0.9 \\
\hline Net change in arrears $((-)=$ reduction $)$ & -0.5 & -0.6 & 0.8 & -0.5 & -1.7 & -1.5 & -1.4 \\
\hline Domestic & -0.5 & -0.8 & 0.2 & -0.4 & -1.7 & -1.5 & -1.4 \\
\hline External & 0.0 & 0.1 & 0.6 & -0.1 & 0.0 & 0.0 & 0.0 \\
\hline Errors and omissions & 0.0 & -1.1 & 0.0 & 0.0 & 0.0 & 0.0 & 0.0 \\
\hline Overall balance, cash basis & -0.6 & -3.1 & -1.5 & -0.5 & -1.2 & -0.8 & -0.5 \\
\hline Identified financing & 0.6 & 3.1 & 1.5 & 0.5 & 1.0 & 0.2 & 0.1 \\
\hline External, net & 0.4 & 0.7 & -0.4 & 0.1 & 0.4 & 0.5 & 0.8 \\
\hline Project loans & 0.5 & 0.8 & 0.4 & 0.8 & 1.0 & 1.0 & 1.3 \\
\hline Program loans & 0.0 & 0.0 & 0.0 & 0.0 & 0.0 & 0.0 & 0.0 \\
\hline Amortization due & -0.7 & -0.1 & -0.8 & -0.7 & -0.6 & -0.5 & -0.5 \\
\hline Exceptional financing & 0.7 & 0.0 & 0.0 & 0.0 & 0.0 & 0.0 & 0.0 \\
\hline Paris Club ${ }^{4}$ & 0.1 & 0.0 & 0.0 & 0.0 & 0.0 & 0.0 & 0.0 \\
\hline Other ${ }^{5}$ & 0.6 & 0.0 & 0.0 & 0.0 & 0.0 & 0.0 & 0.0 \\
\hline Domestic, net & 0.2 & 2.5 & 1.8 & 0.4 & 0.5 & -0.3 & -0.8 \\
\hline Banking system & 1.2 & 2.4 & 1.9 & 0.3 & 0.5 & -0.3 & -0.8 \\
\hline Counterpart to IMF resources (BEAC) & 0.7 & 0.7 & 0.1 & 1.0 & 0.7 & 0.4 & -0.3 \\
\hline Central Bank & 1.8 & 1.3 & 1.3 & -0.2 & -0.2 & -0.7 & -0.4 \\
\hline Commercial banks & -1.3 & 0.5 & 0.5 & -0.4 & 0.0 & 0.0 & -0.1 \\
\hline Nonbank $^{6}$ & -1.0 & 0.0 & 0.0 & 0.1 & 0.0 & 0.0 & 0.0 \\
\hline Residual financing need & 0.0 & 0.0 & 0.0 & 0.0 & 0.2 & 0.6 & 0.5 \\
\hline \multicolumn{8}{|l|}{ Memorandum items: } \\
\hline Total government debt & 35.2 & 41.9 & 42.2 & 38.9 & 36.1 & 32.6 & 29.2 \\
\hline Government domestic debt & 20.4 & 21.2 & 24.8 & 23.0 & 21.6 & 19.6 & 10.7 \\
\hline Spending for DDR & 0.0 & 0.2 & 0.3 & $\ldots$ & $\ldots$ & $\ldots$ & $\ldots$ \\
\hline \\
\hline \multicolumn{8}{|c|}{${ }^{1}$ Expenditure is on a cash basis, except for interest, which is recorded on a due basis. } \\
\hline \multicolumn{8}{|c|}{${ }^{2}$ In 2009 and beyond, includes outlays for the disarmament, demobilization and reintegration (DDR) process. } \\
\hline \multicolumn{8}{|c|}{${ }^{3}$ Excludes grants, interest payments, and externally financed capital expenditure. } \\
\hline \multicolumn{8}{|c|}{${ }^{4}$ Reflects Paris Club rescheduling and moratorium agreement in April 2007.} \\
\hline \multicolumn{8}{|c|}{${ }^{5}$ Includes HIPC debt relief from multilateral and other bilateral creditors. For $2008-09$, also includes debt service } \\
\hline $\begin{array}{l}\text { to non-Paris Club and commercial creditors. Fro } \\
6 \text { Includes repayments to CEMAC commercial b }\end{array}$ & 9 onward, & fte fuld & 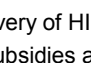 & 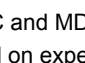 & & . & \\
\hline
\end{tabular}




\begin{tabular}{|c|c|c|c|c|c|c|c|}
\hline & 2009 & 2010 & 2011 & 2012 & 2013 & 2014 & 2015 \\
\hline & & & & Prog. & Prog. & Prog. & Prog. \\
\hline & \multicolumn{7}{|c|}{ (CFAF billions, end of period) } \\
\hline Net foreign assets & 35.0 & 10.3 & 13.3 & 13.9 & 13.7 & 23.2 & 43.7 \\
\hline Bank of Central African States (BEAC) & 21.4 & -0.2 & -4.8 & -5.3 & -8.7 & -1.8 & 13.8 \\
\hline Commercial banks & 13.6 & 10.5 & 18.2 & 19.2 & 22.4 & 25.0 & 30.0 \\
\hline Net domestic assets & 164.6 & 205.8 & 251.0 & 268.8 & 286.0 & 294.2 & 302.7 \\
\hline Domestic credit & 173.0 & 218.6 & 257.6 & 275.4 & 292.6 & 300.8 & 309.3 \\
\hline Credit to the public sector & 109.8 & 130.0 & 152.4 & 160.5 & 172.1 & 169.2 & 161.2 \\
\hline Credit to central government (net) & 111.8 & 138.2 & 164.3 & 168.1 & 174.1 & 171.3 & 163.2 \\
\hline BEAC & 105.2 & 126.9 & 141.7 & 150.4 & 156.7 & 153.3 & 144.5 \\
\hline Treasury account & 21.5 & 22.4 & 23.3 & 22.3 & 22.0 & 21.0 & 17.4 \\
\hline Consolidated loans & 72.8 & 76.1 & 78.1 & 78.9 & 77.2 & 69.4 & 68.0 \\
\hline IMF (net) & 35.7 & 44.6 & 45.7 & 56.9 & 65.3 & 70.7 & 66.9 \\
\hline Deposits & -24.9 & -16.2 & -5.4 & -7.8 & -7.8 & -7.8 & -7.8 \\
\hline Commercial banks & 6.6 & 11.3 & 22.7 & 17.7 & 17.4 & 17.9 & 18.7 \\
\hline Credit to other public agencies (net) & -2.0 & -8.2 & -11.9 & -7.6 & -2.0 & -2.0 & -2.0 \\
\hline Credit to the economy & 63.2 & 88.7 & 105.2 & 114.8 & 120.5 & 131.6 & 148.1 \\
\hline Public enterprises & 1.7 & 1.6 & 2.8 & 2.8 & 2.8 & 2.8 & 2.8 \\
\hline Private sector & 61.5 & 87.0 & 102.4 & 112.0 & 117.7 & 128.8 & 145.2 \\
\hline Other items (net) & -8.4 & -12.8 & -6.6 & -6.6 & -6.6 & -6.6 & -6.6 \\
\hline Money and quasi-money & 157.0 & 179.2 & 206.1 & 234.6 & 240.6 & 259.2 & 280.1 \\
\hline Currency & 78.0 & 94.4 & 105.4 & 127.4 & 129.8 & 158.8 & 144.1 \\
\hline Deposits & 79.0 & 84.8 & 100.7 & 107.1 & 110.8 & 100.4 & 136.0 \\
\hline Demand deposits & 51.3 & 55.0 & 61.7 & 65.6 & 65.9 & 59.7 & 80.9 \\
\hline \multirow[t]{2}{*}{ Term and savings deposits } & 27.6 & 29.8 & 39.0 & 41.5 & 44.9 & 40.6 & 55.0 \\
\hline & \multicolumn{7}{|c|}{ (Annual change, percent of beginning period broad money) } \\
\hline Net foreign assets & 7.6 & -15.7 & 1.7 & 0.3 & -0.1 & 3.9 & 7.9 \\
\hline Net domestic assets & 6.4 & 26.3 & 25.2 & 8.6 & 7.3 & 3.4 & 3.3 \\
\hline Net domestic credit & 9.5 & 29.1 & 21.7 & 8.6 & 7.3 & 3.4 & 3.3 \\
\hline Net credit to central government & 7.7 & 16.8 & 14.6 & 1.8 & 2.6 & -1.2 & -3.1 \\
\hline Credit to the economy & -0.7 & 16.2 & 9.2 & 4.7 & 2.4 & 4.6 & 6.3 \\
\hline \multirow[t]{2}{*}{ Money and quasi-money } & 13.7 & 14.2 & 15.0 & 13.8 & 2.6 & 7.7 & 8.1 \\
\hline & \multicolumn{7}{|c|}{ (Annual percentage change) } \\
\hline Monetary base & 26.8 & 3.4 & 8.1 & 20.1 & 1.9 & 21.0 & -7.8 \\
\hline Credit to the economy & -1.4 & 40.3 & 18.6 & 9.1 & 4.9 & 9.2 & 12.5 \\
\hline Public enterprises & -20.0 & -4.2 & 72.6 & 0.0 & 0.0 & 0.0 & 0.0 \\
\hline Private sector & -0.8 & 41.5 & 17.6 & 9.4 & 5.1 & 9.4 & 12.8 \\
\hline \multicolumn{8}{|l|}{ Memorandum items: } \\
\hline Gross official foreign reserves (CFAF billions) & 66.7 & 62.1 & 57.8 & 60.8 & 67.7 & 76.1 & 86.9 \\
\hline NDA of the central bank (CFAF billions) & 83.4 & 108.5 & 121.9 & 145.9 & 151.9 & 175.2 & 146.1 \\
\hline Monetary base (CFAF billions) & 104.8 & 108.3 & 117.1 & 140.6 & 143.2 & 173.4 & 159.9 \\
\hline Nominal GDP (CFAF billions) & 936 & 984 & 1,036 & 1,123 & 1,193 & 1,296 & 1,401 \\
\hline \multicolumn{8}{|l|}{ Velocity (GDP/broad money) } \\
\hline End of period & 6.0 & 5.5 & 5.0 & 5.0 & 5.0 & 5.0 & 5.0 \\
\hline
\end{tabular}




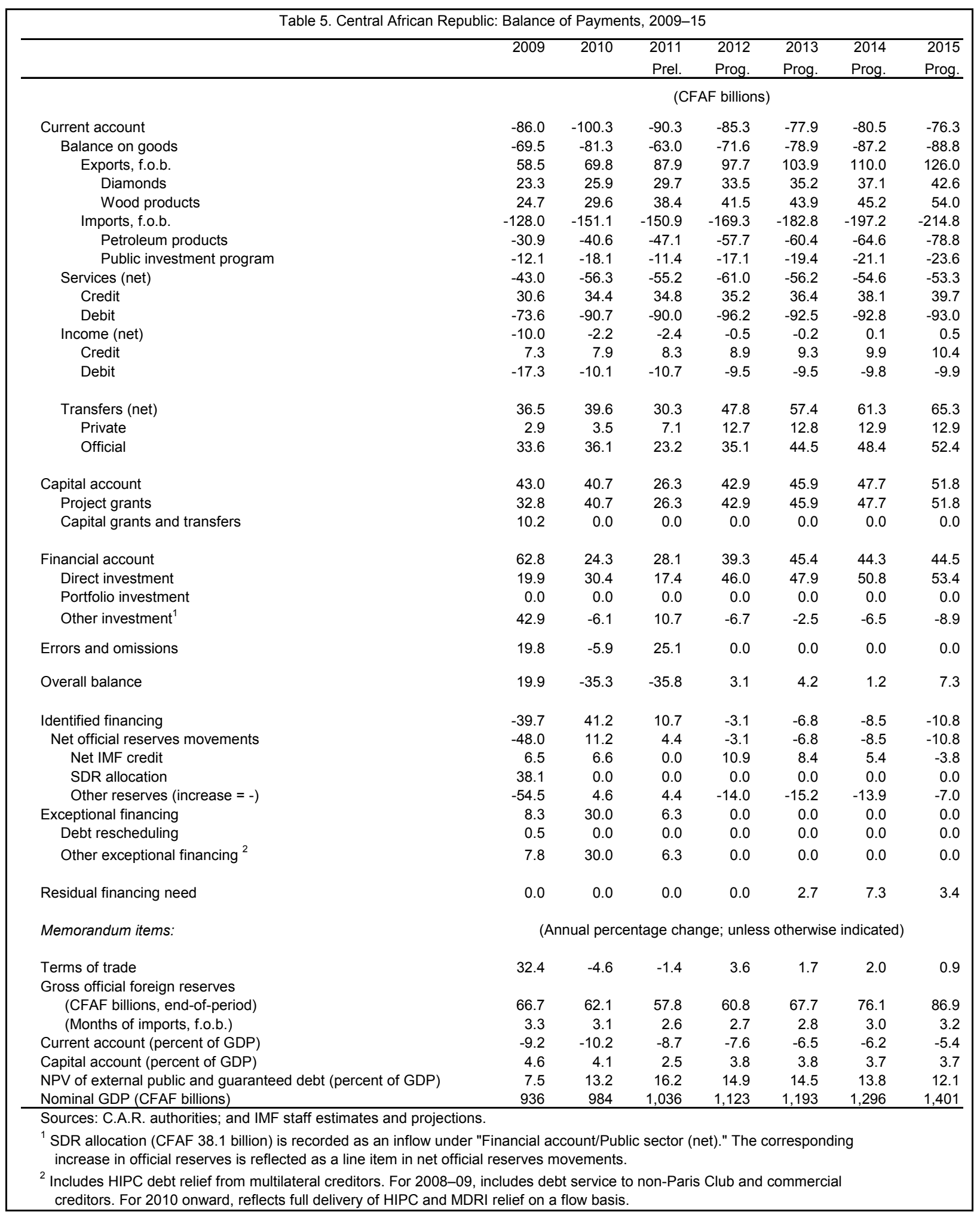


Table 6. Central African Republic: Access and Phasing Under the Three-Year ECF Arrangement ${ }^{1}$

\begin{tabular}{|c|c|c|c|}
\hline \multirow{2}{*}{ Availability Date } & \multicolumn{2}{|c|}{ Disbursements } & \multirow{2}{*}{ Conditions } \\
\hline & (SDRs) & (Percent of quota) & \\
\hline June 25, 2012 & $6,963,000$ & 12.50 & Approval of the arrangement \\
\hline November 15, 2012 & $6,963,000$ & 12.50 & $\begin{array}{l}\text { Disbursed upon observance of end-June } 2012 \text { performance } \\
\text { criteria, and completion of the first review }\end{array}$ \\
\hline May 15, 2013 & $6,963,000$ & 12.50 & $\begin{array}{l}\text { Disbursed upon observance of end-December } 2012 \text { performance } \\
\text { criteria, and completion of the second review }\end{array}$ \\
\hline November 15, 2013 & $5,222,000$ & 9.38 & $\begin{array}{l}\text { Disbursed upon observance of end-June } 2013 \text { performance } \\
\text { criteria, and completion of the third review }\end{array}$ \\
\hline May 15, 2014 & $5,222,000$ & 9.38 & $\begin{array}{l}\text { Disbursed upon observance of end-December } 2013 \text { performance } \\
\text { criteria, and completion of the fourth review }\end{array}$ \\
\hline November 15, 2014 & $5,222,000$ & 9.38 & $\begin{array}{l}\text { Disbursed upon observance of end-June } 2014 \text { performance } \\
\text { criteria, and completion of the fifth review }\end{array}$ \\
\hline May 15, 2015 & $5,220,000$ & 9.37 & $\begin{array}{l}\text { Disbursed upon observance of end-December } 2014 \text { performance } \\
\text { criteria, and completion of the sixth (final) review }\end{array}$ \\
\hline Total & $41,775,000$ & 75.00 & \\
\hline
\end{tabular}




\begin{tabular}{|c|c|c|c|c|c|c|c|c|c|c|c|}
\hline & 2010 & 2011 & 2012 & 2013 & 2014 & 2015 & 2016 & 2017 & 2018 & 2019 & 2020 \\
\hline \multicolumn{12}{|l|}{$\begin{array}{l}\text { IMF obligations based on existing credit } \\
\text { (SDR millions) }\end{array}$} \\
\hline Principal & 0.0 & 0.0 & 0.0 & 1.5 & 3.5 & 10.1 & 13.9 & 12.2 & 8.9 & 6.9 & 1.7 \\
\hline Charges and interest & 0.0 & 0.0 & 0.1 & 0.1 & 0.2 & 0.2 & 0.2 & 0.1 & 0.3 & 0.2 & 0.2 \\
\hline \multicolumn{12}{|l|}{$\begin{array}{l}\text { IMF obligations based on existing and prospective credit } \\
\text { (SDR millions) }\end{array}$} \\
\hline Principal & 0.0 & 0.0 & 0.0 & 1.5 & 3.5 & 10.1 & 13.9 & 12.9 & 12.4 & 12.6 & 9.6 \\
\hline Charges and interest & 0.0 & 0.0 & 0.1 & 0.1 & 0.3 & 0.3 & 0.3 & 0.2 & 0.4 & 0.3 & 0.2 \\
\hline \multicolumn{12}{|l|}{ Total obligations based on existing and prospective credit } \\
\hline SDR millions & 0.0 & 0.0 & 0.1 & 1.6 & 3.8 & 10.4 & 14.2 & 13.1 & 12.8 & 12.9 & 9.8 \\
\hline CFAF billions & 0.0 & 0.0 & 0.0 & 1.2 & 3.0 & 8.1 & 11.1 & 10.3 & 10.0 & 10.1 & 7.7 \\
\hline Percent of government revenue & 0.0 & 0.0 & 0.0 & 0.9 & 1.9 & 4.5 & 5.5 & 4.6 & 4.1 & 3.7 & 2.6 \\
\hline Percent of exports of goods and services & 0.0 & 0.0 & 0.0 & 0.9 & 2.0 & 5.1 & 6.4 & 5.5 & 4.9 & 4.7 & 3.3 \\
\hline Percent of debt service ${ }^{2}$ & 0.1 & 0.1 & 0.1 & 2.9 & 6.8 & 19.0 & 26.6 & 51.6 & 57.8 & 64.1 & 48.4 \\
\hline Percent of GDP & 0.0 & 0.0 & 0.0 & 0.1 & 0.2 & 0.6 & 0.7 & 0.6 & 0.6 & 0.5 & 0.4 \\
\hline Percent of quota & 0.1 & 0.1 & 0.1 & 2.8 & 6.9 & 18.6 & 25.5 & 23.5 & 22.9 & 23.2 & 17.6 \\
\hline \multicolumn{12}{|l|}{ Outstanding IMF credit $^{2}$} \\
\hline SDR millions & 58.7 & 58.7 & 71.3 & 82.0 & 88.9 & 84.1 & 70.2 & 56.5 & 44.1 & 27.2 & 11.5 \\
\hline CFAF billions & 44.4 & 45.7 & 55.9 & 64.3 & 69.7 & 65.9 & 55.0 & 44.3 & 34.6 & 21.3 & 9.0 \\
\hline Percent of government revenue & 38.8 & 40.9 & 43.6 & 46.0 & 44.1 & 36.6 & 27.3 & 19.8 & 14.1 & 7.8 & 3.0 \\
\hline Percent of exports of goods and services & 42.6 & 37.2 & 42.0 & 45.8 & 47.0 & 41.3 & 31.8 & 23.6 & 17.1 & 9.8 & 3.9 \\
\hline Percent of debt service $^{2}$ & 177.5 & 202.2 & 136.6 & 150.3 & 158.7 & 154.1 & 131.7 & 222.8 & 199.8 & 134.8 & 56.9 \\
\hline Percent of GDP & 4.5 & 4.4 & 5.0 & 5.4 & 5.4 & 4.7 & 3.6 & 2.7 & 2.0 & 1.1 & 0.4 \\
\hline Percent of quota & 105.4 & 105.4 & 128.1 & 147.3 & 159.7 & 151.0 & 126.0 & 101.5 & 79.2 & 48.8 & 20.7 \\
\hline Net use of IMF credit (SDR millions) & 8.7 & 0.0 & 12.6 & 10.7 & 6.9 & -4.8 & -13.9 & -13.7 & -12.5 & -16.9 & -15.7 \\
\hline Disbursements & 8.7 & 0.0 & 13.9 & 12.2 & 10.4 & 5.2 & 0.0 & 0.0 & 0.0 & 0.0 & 0.0 \\
\hline Repayments and repurchases & 0.0 & 0.0 & 1.3 & 1.5 & 3.5 & 10.1 & 13.9 & 13.7 & 12.5 & 16.9 & 15.7 \\
\hline \multicolumn{12}{|l|}{ Memorandum items: } \\
\hline Nominal GDP (billions of CFA francs) & 983.6 & 1035.6 & 1122.9 & 1193.1 & 1295.8 & 1400.6 & 1513.1 & 1630.2 & 1762.1 & 1903.7 & 2059.5 \\
\hline Exports of goods and services (in billions of CFA francs) & 104.2 & 122.8 & 133.0 & 140.3 & 148.2 & 159.6 & 172.7 & 187.9 & 201.9 & 217.2 & 233.9 \\
\hline Government revenue (in billions of CFA francs) & 114.2 & 111.8 & 128.1 & 139.8 & 158.2 & 179.9 & 201.8 & 224.2 & 245.2 & 271.7 & 301.5 \\
\hline Debt service (in billions of CFA francs) ${ }^{2}$ & 25.0 & 22.6 & 40.9 & 42.8 & 43.9 & 42.8 & 41.8 & 19.9 & 17.3 & 15.8 & 15.9 \\
\hline
\end{tabular}


Table 8. Central African Republic: Selected Financial Soundness Indicators, 2007-11 (Percent)

\begin{tabular}{|c|c|c|c|c|c|}
\hline & 2007 & 2008 & 2009 & 2010 & 2011 \\
\hline \multicolumn{6}{|l|}{ Solvency } \\
\hline Regulatory capital to risk-weighted assets & 16.2 & 17.3 & 16.3 & 16.1 & 25.0 \\
\hline Tier 1 capital to risk-weighted assets & 16.3 & 17.7 & 17.0 & 16.5 & 24.0 \\
\hline General provisions for risk-weighted assets & 0.5 & 0.6 & 0.2 & 0.2 & 0.2 \\
\hline Capital to total assets & 16.2 & 16.7 & 18.8 & 19.2 & 24.2 \\
\hline \multicolumn{6}{|l|}{ Asset quality } \\
\hline Total loans to total assets & 76.0 & 76.2 & 67.6 & 74.1 & 69.1 \\
\hline Non-performing loans (gross) to total loans & 30.4 & 21.3 & 21.3 & 13.9 & 14.7 \\
\hline Non-performing loans (net of provisioning) to total loans & 5.1 & 3.7 & 5.7 & 1.0 & 3.2 \\
\hline Provisioning rate & 83.1 & 82.9 & 73.3 & 92.8 & 77.9 \\
\hline Non-performing loans (net of provisioning) to capital & 24.1 & 16.7 & 20.5 & 3.8 & 9.3 \\
\hline \multicolumn{6}{|l|}{ Liquidity } \\
\hline Total loans to total deposits & 111.5 & 116.9 & 99.3 & 113.3 & 107.8 \\
\hline Total deposits to total liabilities & 68.2 & 65.2 & 68.1 & 65.4 & 64.1 \\
\hline Total sight deposits to total liabilities & 52.0 & 46.4 & 50.0 & 49.6 & 45.7 \\
\hline Total term deposits to total liabilities & 10.3 & 11.2 & 10.7 & 8.4 & 10.8 \\
\hline \multicolumn{6}{|l|}{ Earnings and profitability ${ }^{1}$} \\
\hline Returns on capital & 21.0 & 13.0 & 7.8 & 13.3 & 10.2 \\
\hline Staff costs to operating revenue & 15.3 & 19.3 & 21.9 & 20.8 & 19.1 \\
\hline Non-interest expenses to operating revenue & 47.0 & 53.0 & 58.2 & 54.1 & 49.2 \\
\hline Gross interest margin to total assets & 6.7 & 6.1 & 8.1 & 7.2 & 4.0 \\
\hline
\end{tabular}
Source: BEAC and Central African Banking Commission (COBAC).

${ }^{1}$ Data for 2011 as of June 30. 


\title{
APPENDIX I
}

\section{Translated From French}

Central African Republic

\section{LETTER OF INTENT}

Bangui, June 11, 2012

\author{
Madame Christine Lagarde \\ Managing Director \\ International Monetary Fund \\ 700 19th ST, NW \\ Washington, DC, 20431 \\ USA
}

Dear Madame Managing Director,

The government of the Central African Republic (C.A.R.) undertook, in the wake of the 2010-11 electoral process, to restore fiscal discipline, revitalize the mechanism for monitoring liquidity, and accelerate structural reforms. To this end, the government has implemented the reform of the Treasury Single Account (TSA), strengthened the institutional framework for cash management, and simplified the tax system. Following the adoption of its second generation Poverty Reduction Strategy Paper (PRSP II) for 2011-15, the government, in consultation with IMF staff, prepared an economic and financial program to support economic recovery for which it is seeking IMF assistance in the amount of SDR 41.775 million under an Extended Credit Facility (ECF) arrangement, including a disbursement equivalent to SDR 6.963 million upon Executive Board approval of this arrangement.

The government believes that the policies set forth in the attached Memorandum on Economic and Financial Policies (MEFP) will enable it to meet its program objectives but is ready to take any additional measures that might be necessary. The government of the C.A.R. will consult with the IMF on the adoption of these measures, and in advance of revisions to the policies contained in the MEFP, in accordance with the Fund's policies on such consultation. Moreover, we will provide the Fund with such information as the Fund requests in connection with the progress in implementing the policies and reaching the objectives of the program. 
The government has implemented the prior actions for consideration by the Executive Board of its request for support under the ECF, namely the adjustment in domestic petroleum prices and the preparation of an annual cash flow plan with a monthly breakdown taking into account the fiscal targets included in the program for 2012-13, in line with the provisions of $q 18-20$ of the MEFP.

The government intends to make the contents of this letter and the attached MEFP, as well as the associated IMF staff report, available to the public. Therefore, we authorize the IMF to publish these documents on the IMF website once the Executive Board has concluded its consideration of our request.

Sincerely yours,

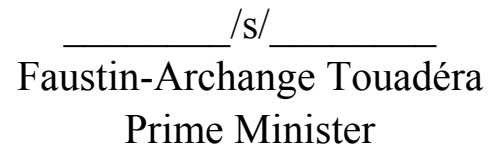

Prime Minister

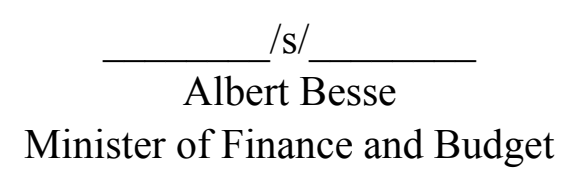

Attachments: Memorandum on Economic and Financial Policies

Technical Memorandum of Understanding 


\title{
APPENDIX I ATTACHMENT I
}

\section{TransLated From FrenCH}

Central African Republic

\section{Memorandum on Economic And Financial Policies, 2012-15}

\author{
Bangui, June 11, 2012
}

\section{INTRODUCTION}

1. The Central African Republic (C.A.R.) exhibits, in many respects, the characteristics of a fragile state. Economic conditions have improved since end-2006 when the government began implementing its medium-term macroeconomic and financial program supported by the IMF's Extended Credit Facility (ECF). Political and social stability has been strengthened as a result of the Inclusive Political Dialogue (IPD) held in December 2008. While there were delays in mobilizing resources for the Demobilization, Disarmament and Reintegration (DDR) program, the pace picked up in 2010, thus contributing to national reconciliation and paving the way for the presidential and legislative elections in 2011. Nonetheless, these achievements remain fragile.

2. The economy is gradually recovering from the impact of the global economic slowdown, which hit the country very hard. We reacted quickly to strengthen our management of the economy and protect the most vulnerable segments of the population. With continuous support from the international community, we are determined to intensify our efforts and implement vigorous policies aimed at further stabilizing our economy and building the foundations for sustainable economic growth.

3. This memorandum presents the government's economic and financial policies for the period 2012-15. The priorities and objectives of the program are consistent with the second generation Poverty Reduction Strategy Paper (PRSP II) adopted in November 2011, which was the subject of extensive consultations with major stakeholders. In the context of the implementation of PRSP II, an inventory aimed at compiling an exhaustive list of national projects with the most realistic financing plans is being prepared with technical assistance from the World Bank. The final document is expected to be submitted by the end of the year to a Consultative group (CG) with a view to mobilizing the required financing. We remain committed to implementing the priorities of PRSP II, and to laying the foundation for accelerated and sustained growth conducive to reducing poverty and making progress toward reaching the Millennium Development Goals (MDGs), as this is an area in which C.A.R.'s performance is significantly lagging. Lastly, the main objective of the core strategy for the reform of the security sector is to improve security and consolidate peace. 


\section{Recent Economic Performance And Policies}

\section{A. Macroeconomic Performance in 2011}

4. The economic recovery is gaining ground. After bottoming out at 1.7 percent in 2009, economic growth picked up, reaching 3 percent and 3.3 percent in 2010 and 2011, respectively. This performance is largely attributable to favorable weather conditions economic environment and improved security in the production areas. Buoyant activity in the primary sector, in particular subsistence and livestock farming, continues to underpin economic recovery. Credit to the private sector was robust in 2011, increasing by almost 18 percent. While the bulk of this credit consisted of short-term loans, this increase nevertheless signals a slight upturn in economic activity. Average inflation continued its downward trend, dropping to 1.2 percent in 2011, after peaking at 9.3 percent in 2008, owing essentially to the surge in global food and fuel prices.

5. Budget execution in 2010 and 2011 showed significant weaknesses. Exceptional procedures were used with increasing frequency in paying for government expenditure, circumventing normal budget procedures executed through the electronic expenditure chain management system, Gesco. The Treasury, through the issuance of cash payment orders (OP-Caisse), and the Directorate General of the Budget, in the form of budgetary payment orders $(O P-B u d g e t)$, accounted for the bulk of the use of exceptional payment procedures in 2010 and 2011, respectively. Priority spending for which budget allocations had been set aside suffered the most from these practices, resulting in the accumulation of domestic payments arrears amounting to CFAF 11.1 billion as of end-2011 (1.1 percent of GDP). Appropriate measures taken to deal with the problem meant that, at the end of 2011, cash payment orders were reduced to 7 percent of current expenditure, excluding wages and finance charges, compared to 80 percent in 2010 . We recognize that further efforts need to be made to reach the 5 percent ceiling that we have set ourselves for the last three quarters of 2012. With that in mind, and with assistance from the European Union (EU), we have undertaken to conduct an audit of arrears accumulated through 2010 with the view to devising a plan for clearing these arrears. We are currently in talks with the EU to extend the scope of this audit to include 2011.

6. Poor budget execution also resulted in the accumulation of new external debt payment arrears of CFAF 11.6 billion at end-2011, of which CFAF 1.01 billion were owed to one Paris Club creditor (France), CFAF 9 billion to bilateral non-Paris Club creditors, ${ }^{1}$ CFAF 0.4 billion to the European Investment Bank (EIB), and CFAF 1.3 billion to external private creditors. Progress was achieved in bilateral negotiations with both Paris and non-Paris Club creditors. Debt rescheduling and partial cancellation agreements were concluded with some creditors, while negotiations are ongoing with Russia and the United Kingdom as well as with non-Paris Club creditors. We are making good faith efforts to reach collaborative agreements with our external private creditors.

\footnotetext{
${ }^{1}$ Comprising Equatorial Guinea, India, Kuwait, Libya, Saudi Arabia, and Taiwan Province of China.
} 
7. In the external sector, in 2011 the current account deficit fell to 8.7 percent of GDP compared to 10.2 percent in 2010, owing mainly to the stronger performance of exports and the stabilization of imports. Exports rebounded in response to improvements in the international economic situation in 2010, rising by 32.3 percent in value. This strong performance in exports in 2011, coupled with a fall of around 18 percent of the volume of imports, led to the improvement in the external current account. In regard to financing, the mining, telecommunications, and transport sectors benefitted from higher foreign direct investment (FDI) flows.

\section{B. Structural Reforms}

8. The government has restarted the structural reform process. Following lax implementation of structural reforms during the pre- and post-electoral period, starting from November 2011, the government renewed its commitment to pursuing structural reforms to strengthen budget management and the monitoring of macroeconomic developments. Thus, based on the recommendations of IMF Technical Assistance (TA) missions, including by AFRITAC Center, as well as by technical and financial partners (TFPs), we have revitalized and streamlined the entities responsible for the monitoring of budget execution and liquidity. We have also strengthened the revenue collection agencies, in particular, the Revenue Authority (DGID), which implemented several actions in 2011 aimed at enhancing its performance, notably:

- $\quad$ Updating registered taxpayers' files;

- $\quad$ Enhancing the registration procedure;

- Improving the efficiency of tax control (use of information, program streamlining, higher quality audits).

9. The Treasury has started the process of streamlining its operations. We have created a Treasury Single Account (TSA) and reduced the number of accounts held with commercial banks to one account per bank (with two transfer accounts and accounts required by donors for project management purposes). However, in keeping with our new fiscal decentralization regulations, which provides for a share of the revenues from the provinces to be spent on local projects and gives the revenue collection agencies autonomy for managing a share of the fees they collect to meet their current spending needs, a limited number of decentralized accounts are, for the moment, still being held with commercial banks. All salaries are paid by bank transfer and we have made good progress in extending this mode of payment to retirees and to the government's regular suppliers. Initial results are encouraging. In light of these new banking services, we are currently in negotiation with commercial banks to reach agreement on clearly defined bank fees and interest and, consequently, encourage competition among them in line with CEMAC's regulations on the overall effective rate and the usury rate adopted by the Ministerial Committee of the Central African Monetary Union (UMAC) on April 5, 2012. 


\section{Macroeconomic ObJectives ANd Medium-Term Policies}

10. Program priorities for 2012-15 are in line with the strategic objectives of PRSP II, and are aimed at (i) consolidating macroeconomic stability by quickly restoring fiscal discipline; (ii) creating fiscal space through increased mobilization of domestic revenues, improved spending priorities and greater efficiency in government expenditure;

(iii) strengthening human and institutional capacity; and (iv) removing obstacles to higher economic growth. In implementing PRSP II, the government will give priority to:

(i) developing basic infrastructure (energy and roads) to overcome challenges faced by C.A.R. as a landlocked country and boost its competitiveness; (ii) implementing policies aimed at diversifying production, including by creating development clusters; and (iii) human and institutional capacity building.

11. The medium-term macroeconomic framework assumes a gradual improvement in macroeconomic aggregates. In the context of the improved security situation in the country, the average rate of growth for the program period is projected at 4.7 percent based on a resumption of investment in the mining sector and a sustained expansion of agricultural production (both food and export crops). Given the sharp rise in prices seen in the first quarter of 2012, inflation is expected to rise over the course of the year before falling in 2013 below CEMAC's convergence criterion. The current account deficit is projected to stabilize at just over 6 percent of GDP by 2014, as total imports are pushed up by rising imports of petroleum products.

12. The policies we intend to implement under the program will focus on stepping up domestic revenue mobilization, strengthening public financial management (PFM), and improving the business environment.

13. With respect to revenue mobilization we are aware that, at an average of 10.5 percent over 2006-10, the ratio of revenue to GDP is very low. Our efforts in this area are expected to yield additional resources amounting to 1.4 percentage points of GDP by 2014. To this end, we intend to prepare and implement a comprehensive reform policy covering the revenue collection agencies. One of the main expected outcomes of this initiative is the in-depth reform of the tax services and reorganization of the customs administration on the basis of the recommendations of IMF TA missions. Regarding tax administration, with the assistance of the IMF and the EU, reform will focus on simplification of the income tax system, more effective and better tailored taxation of small enterprises, and strict control of spending related to tax collection. Key aspects of the reform include the: (i) development of tools to enhance monitoring of the self-assessment system and improve the supervision of small enterprises so as to improve the taxation of such taxpayers; (ii) systematic reconciliation of the registered taxpayer files with physical taxpayer files; (iii) identification and systematic location of taxpayers in the field; (iv) modernization of the SYSTEMIF application (version 4) to include functionalities enabling data searches and cross checks, and make the application source programs available to the DGID; and (v) strengthening of the capacities of inspectors, as a priority, and of other DGID staff, in general. The DGID will continue its modernization efforts. As regards the customs services, the reform effort will focus primarily on 
pursuing the implementation of the customs modernization plan devised with the support of the World Customs Organization, bringing the Beloko customs clearance center on stream and making use of the two scanners donated by China, continuing fraud prevention efforts, and strictly controlling exemptions.

\begin{tabular}{|l|c|}
\hline Revenue Mobilization Measures & Timing \\
\hline Tax Reforms & Done; continuous \\
\hline Adjust petroleum product prices monthly & 2012 \\
Streamline petroleum product price structure & 2012 \\
Implement targeted support for groups vulnerable to fuel price & March 2013 \\
increases & March 2013 \\
Reconcile registered taxpayer files with physical taxpayer files & June 2013 \\
Update and secure single taxpayer ID system & June 2013 \\
Operationalize the pilot taxation center for medium-sized enterprises & TBD \\
Identify and systematically locate taxpayers in the field & TBD \\
Modernize SYSTEMIF, enabling data searches and cross-checks, and & TBD \\
make it available to DGID & TBD \\
Strengthen capacities of inspectors and other DGID staff & \\
Enhance monitoring of the tax self-assessment system & TBD \\
Improve taxation of small enterprises & TBD \\
\hline Customs Reforms & TBD \\
\hline Implement modernization plans with WCO support & TBD \\
Operationalize the Beloko customs clearance center & \\
Utilize scanners & \\
Strictly limit exemptions & The \\
\hline
\end{tabular}

$\mathrm{TBD}=$ To be determined at the time of the first program review, based on the recommendations of an FAD mission to C.A.R. in June 2012.

14. With respect to PFM, our priorities are to (i) strengthen liquidity management, (ii) improve expenditure tracking and budget monitoring, and (iii) enhance debt management. We intend to adopt by 2014 a medium-term expenditure framework (MTEF) consistent with the CEMAC guidelines. In the meantime, we intend to streamline and simplify the expenditure chain and ensure that Gesco is fully operational by June 2013, by extending its functionalities to Treasury operations and taking on board the recommendations of the audit of the expenditure chain, financed by the EU and currently underway. The government requested support from the EU to commission an audit of the functional and administrative expenditure chain and from the IMF to implement the initial recommendations of FAD's February 2012 TA mission. Based on these recommendations, the government has prepared an action plan, which it plans to follow. 


\begin{tabular}{|c|c|}
\hline Expenditure and Debt Management & Timing \\
\hline \multicolumn{2}{|l|}{ Expenditure Measures } \\
\hline Set up CSGB to set caps on spending commitments bimonthly & Done \\
\hline $\begin{array}{l}\text { Prepare annual cash-flow plan broken down into quarterly and monthly } \\
\text { plans }\end{array}$ & Done \\
\hline Create mechanism for data sharing and the Budget Directorate & July 2012 \\
\hline Report monthly execution data on externally financed capital spending & September 2012 \\
\hline $\begin{array}{l}\text { Limit the use of exceptional payment procedures to } 5 \text { percent of } \\
\text { nonwage, noninterest current spending and domestically financed } \\
\text { investment }\end{array}$ & Quarterly \\
\hline $\begin{array}{l}\text { Strengthen capacity of the technical secretariat of the CSL and the } \\
\text { Treasury's technical unit on liquidity monitoring }\end{array}$ & December 2012 \\
\hline $\begin{array}{l}\text { Implement an action plan to implement the recommendations of FAD } \\
\text { February } 2012 \text { mission }\end{array}$ & December 2012 \\
\hline Streamline and simplify expenditure chain & June 2013 \\
\hline Fully operationalize Gesco & 2013 \\
\hline Extend Gesco's coverage to Treasury operations & 2013 \\
\hline Implement recommendations of the expenditure chain audit & 2013 \\
\hline Adopt MTEF consistent with CEMAC guidelines & 2014 \\
\hline \multicolumn{2}{|l|}{ Debt Management } \\
\hline Operationalize the CNDP & September 2012 \\
\hline Adopt credible plan to clear audited domestic arrears & March 2013 \\
\hline
\end{tabular}

15. We recognize that improving the business environment is essential to boost muchneeded private investment and contribute to the development of our country. Over the medium term, the government intends to create a business friendly environment by strengthening the judicial system and the legal framework as well as simplifying the land tenure system, and boosting access to financing. It will also finalize the review of the investment charter and of the commercial code and enhance the role of the commercial court.

16. Clearance of domestic payment arrears will be accelerated as resource becomes available. Following completion of the audit of these arrears (\$5); we will adopt by March 2013 a plan to clear them on the basis of transparent criteria. Should budget 
support be higher than programmed, 50 percent of the excess will be used for arrears clearance.

\begin{tabular}{|c|c|}
\hline Measures to Improve the Business Environment & Timing \\
\hline \multicolumn{2}{|l|}{ Private Sector Engagement } \\
\hline Set up a framework for dialogue with the private sector & End-June 2012 \\
\hline Revitalize the Standing Consultative Group (CPC) & September 2012 \\
\hline $\mathrm{CPC}$ to make proposals on improving the business environment & December 2012 \\
\hline Review SODIF's performance and take appropriate actions & December 2012 \\
\hline \multicolumn{2}{|l|}{ Institutional Measures } \\
\hline $\begin{array}{l}\text { Align natural resources management framework with international } \\
\text { best practices }\end{array}$ & September 2013 \\
\hline Strengthen judicial and legal framework & 2014 \\
\hline Improve the land tenure system & 2014 \\
\hline Boost access to financing & 2014 \\
\hline Finalize review of the investment charter & 2014 \\
\hline $\begin{array}{l}\text { Finalize review of the Commercial Code and enhance the role of the } \\
\text { Commercial Court }\end{array}$ & 2014 \\
\hline
\end{tabular}

IV. Program for 2012-13

17. Real GDP growth is expected to strengthen, rising to 4.1 percent in 2012 compared to 3.3 percent in 2011 as a result of strong agricultural production, more robust domestic demand and higher exports, in particular in the diamond and timber sectors. Given the price surge recorded in the first quarter of 2012, annual average inflation is projected to reach 6.8 percent for the whole year. The external current account deficit is expected to continue trending downwards, settling at 7.6 percent of GDP. FDI will be buoyed mainly by the mining sector-in particular, by the Aurafrique/Axmin project and oil exploration in the north-east of the country - rising to a projected total of CFAF 46 billion in 2012.

\section{A. Fiscal Policy}

18. The fiscal policy objectives for $2012-13$ are to: (i) initiate the consolidation process by bringing current spending down from 2011 levels, and by achieving a modest increase in revenue; and (ii) strengthen budget execution and public financial management through spending controls and transparent recording of expenditure and 
domestic revenues with a view to generating a small surplus ( 0.6 percent of GDP) on the domestic primary balance. We have also set ourselves the further objective of normalizing relations with external creditors.

19. Domestic resource mobilization efforts will be intensified. Domestic revenues are forecast at CFAF 128.1 billion (11.4 percent of GDP), and current primary expenditure at CFAF 105.1 billion (9.4 percent of GDP). Over the remainder of the current year, we are committed to adjusting the composition of expenditure in line with the main components of the budget, as regards both current and capital spending. To safeguard fiscal revenue, we adjusted petroleum product prices in January 2012. However, the level of adjustment was not enough to eliminate the consumer subsidy allocated through the single tax on petroleum products (negative TUPP). We have increased prices on June 1 (prior action) and we plan to adjust petroleum product prices on a monthly basis for effective passthrough of world market prices to pump prices, thus eliminating the negative TUPP and safeguarding projected budget revenues from the taxation of petroleum products. In parallel, we intend to request TA from our TFPs to streamline the price structure further. Correct application of the value added tax (VAT) on petroleum products will be maintained so as to preserve the integrity of the VAT and revenues from the sector. In addition, we plan to implement a targeted support mechanism for the most vulnerable segments of society in order to mitigate the potential adverse effects of a fuel price increase on such groups.

20. To strengthen budget execution, we have prepared an annual cash-flow plan (prior action). This plan, based on the program fiscal targets, is broken down into quarterly and monthly sub-plans to facilitate closer monitoring and the setting of expenditure commitment ceilings consistent with available liquidity. The budget will be executed in conformity with applicable regulatory provisions. As mentioned above ( 8), a Liquidity Monitoring Commission (CSL) and technical units as well as a Budget Management Monitoring Committee (CSGB) have been set up to enhance the monitoring of liquidity and fiscal management. The CSGB will hold bimonthly meetings to set ceilings on expenditure commitments. So as to strengthen expenditure prioritization, we are introducing qualitative improvements to simplify the functioning of these entities. These reforms are designed to improve the control, monitoring and level of information on government liabilities vis-à-vis commercial banks. Further, quarterly budget execution reports are now published, in the interest of transparency and disclosure of the government's fiscal policy. In that same vein, we have published the 2012 budget law. The government is also committed to limiting the recourse to exceptional payment to no more than 5 percent of nonwage, noninterest current spending and domestically financed investment for the remaining three quarters of 2012.

\section{B. Capacity and Institution Building Policies}

21. There is a vital need to build human and institutional capacities. We are aware that the capacity weaknesses of our administration and of some of our institutions hinder efficient management of the economy and the capacity to absorb resources. To address these issues, we intend to strengthen our cooperation with development partners to 
enhance the effectiveness of TA resources and improve our operational capacity. As mentioned above, we have put in place a number of committees responsible for budget execution and control, liquidity management, and the monitoring of macroeconomic developments and structural reforms. Although the CSL is already operational, we are striving to make it more efficient so that it can contribute more effectively to strengthening budget execution and preventing the accumulation of payments arrears, especially by regulating the flow of expenditures upstream through rigorous programming of expenditures at the commitment stage. In that regard, we intend to strengthen the capacity of the technical secretariat of the CSL and the technical unit of the Treasury to ensure better coordination in preparing and executing the cash management plan.

22. We are fully cognizant of the need to capitalize on the TA being provided. To this end, donor coordination is essential and we intend to hold regular meetings to ensure complementarities and avoid duplication. In association with our development partners, we are planning to adopt a policy aimed at supporting experienced senior staff to foster professional stability and harness their skills and knowledge to strengthen our administrative capacity.

23. Absorptive capacity of resource flows needs to be improved. To ensure efficient and transparent execution of projects, we will take steps to (i) prioritize investment programming on a realistic basis; (ii) improve the technical preparation of projects; (iii) enhance the pre-commitment process in the technical departments; (iv) ensure compliance with government procurement rules; and (v) maintain a continuous flow of information on project execution, particularly on financial data, to the Ministry of Finance to facilitate cash flow monitoring.

\section{External Sector Policies}

24. Despite the improvement in the export performance, which is expected to continue in 2012, the external position remains fragile as evidenced by the persistent current account deficit (6.2 percent by 2014). The aim of our external sector policies is to boost exports so as to raise C.A.R.'s contribution to the central bank's pool of foreign exchange reserves. Given the low level of reserves coverage of imports of goods and services (2.6 months at end-2011), IMF assistance under the ECF arrangement will contribute to a small build up of reserves.

25. We are mindful of the risk of deterioration in the debt indicators, even despite reaching the completion point of the Heavily Indebted Poor Countries (HIPC) Initiative and having benefited from debt relief under the Multilateral Debt Relief Initiative (MDRI) in 2009. We intend to strengthen public debt management and implement a prudent debt policy. The Department of Debt and Equity Participation (DDP) is to be strengthened and called upon to play an effective role in all debt negotiations. On a more general note, we have established a National Committee on Public Debt (CNDP), for which the relevant legislative texts have already been prepared, with responsibility for oversight of long-term debt sustainability. The CNDP will officially become operational in September 2012, following the validation of the legislative texts governing its functioning. We are committed to consulting IMF staff on all new loans that we plan to 
contract — before signing the loan agreement — so as to ensure compliance with the minimum concessionality requirement of 35 percent.

\section{Other Structural Policies}

26. Financial sector. The government reaffirms its commitment to finding a strategic shareholder to takeover its equity stake in the CBCA. In the context of the restructuring, pursuant to the recommendations of the joint shareholders' meeting of June 2011 that signed off on the 2010 accounts and agreed to the bank's recapitalization plan, the government has made approximately CFAF 5.5 billion available to the CBCA to temporarily acquire 57 percent of the bank's shares pending the entry of the strategic shareholder. We are committed to continuing our efforts to revitalize and privatize the bank. With a view to completing the process, COBAC recently extended the mandate of the temporary administrator of the bank by three months.

27. Public enterprises. Good management of public enterprises and offices (EOPs) is another of the government's priorities. The transitional measures adopted in January 2012 have made it possible to discover slippages in the financial management of the entities concerned and to take corrective measures. We are planning to restore the bodies of the EOPs to their normal mode of functioning and to impose requirements for their regular reporting and sound management to facilitate the proper exercise of government oversight. Implementation of remedial measures will continue with all parties concerned and with support from the TFPs.

28. Good governance and transparency. The government is determined to strengthen good governance and ensure the efficient use of public resources. In the interest of transparency, we intend to continue the process of bringing all government accounts within the scope of the TSA, in particular, those related to bonus payments in respect of natural resource exploitation, in conformity with the Extractive Industries Transparency Initiative (EITI), and regarding the licensing of mobile telephone companies. In compliance with centralized cash management, we are committed to incorporating any windfall revenues received into the budget. As we begin industrial exploitation of C.A.R.'s mineral resources, we will seek TA to put in place a framework for effectively managing these resources.

29. Business environment. The government will effectively renew the dialogue with the private sector. By June 30, 2012 a framework for a dialogue will be put in place and will, first of all, be entrusted with identifying existing bottlenecks and revitalizing the Standing Consultative Steering Group (CPC) to come up with a set of proposals by December 31, 2012 aimed at improving the business environment. Further, the government has decided to undertake a performance assessment of SODIF, whose activities seem to have strayed somewhat from the terms of its original contract, in order to determine whether that is in fact the case and take the appropriate decisions. 


\section{E. Program Monitoring}

30. Performance under the program would be monitored through quantitative performance criteria, indicative targets, and structural benchmarks. Quantitative performance criteria have been set for end-June and end-December 2012, and indicative targets have been set for end-September 2012 and March 2013 (Table I.1). The prior actions under the ECF arrangement and the structural benchmarks are described in Table I.2. The first program review would be completed before December 15, 2012, based on end-June 2012 test date, and the second review would be completed before June 15, 2013, based on end-December 2012 test date. 


\begin{tabular}{|c|c|c|c|c|c|c|}
\hline & $\begin{array}{l}\text { End-December } \\
2011 \\
\mathrm{SM} / 12 / 12\end{array}$ & $\begin{array}{c}\text { End-March } 2012 \\
\text { Indicative Targets } \\
\text { Prel. }\end{array}$ & $\frac{\frac{\text { End-June 2012 }}{\text { Performance Criteria }}}{\text { Program }}$ & $\begin{array}{c}\text { End-Sept. } 2012 \\
\text { Indicative Targets } \\
\text { Program }\end{array}$ & $\frac{\text { End-Dec. 2012 }}{\frac{\text { Performance Criteria }}{\text { Program }}}$ & $\frac{\text { End-March } 2013^{\text {Indicative Targets }^{1}}}{\text { Program }}$ \\
\hline \multicolumn{7}{|l|}{ Performance criteria } \\
\hline Floor on total domestic government revenue ${ }^{2}$ & 111.8 & 32.6 & 66.6 & 96.1 & 128.1 & 34.5 \\
\hline Floor on domestic primary fiscal balance ${ }^{3,4}$ & -13.6 & 6.0 & 6.2 & 6.0 & 6.3 & 4.0 \\
\hline $\begin{array}{l}\text { Net domestic financing } \\
\text { New nonconcessional external debt contracted or }\end{array}$ & 20.7 & -3.1 & -1.2 & -2.4 & 4.3 & 1.6 \\
\hline guaranteed by the government ${ }^{6,7}$ & 0.0 & 0.0 & 0.0 & 0.0 & 0.0 & 0.0 \\
\hline Accumulation of new external payments arrears ${ }^{7}$ & $\ldots$ & 0.0 & 0.0 & 0.0 & 0.0 & 0.0 \\
\hline \multicolumn{7}{|l|}{ Indicative targets } \\
\hline Floor on poverty-related spending ${ }^{8}$ & $\ldots$ & 5.0 & 12.0 & 15.0 & 30.0 & 7.0 \\
\hline Floor on the reduction in domestic payments arrears ${ }^{9}$ & $\ldots$ & 0.0 & 0.0 & 2.5 & 5.0 & 5.0 \\
\hline Ceiling on accumulation of new domestic payment arrears & $\ldots$ & 0.0 & 0.0 & 0.0 & 0.0 & 0.0 \\
\hline \multicolumn{7}{|l|}{ Memorandum item: } \\
\hline Projected grants for budget support & 0.0 & 2.2 & 2.2 & 8.4 & 11.0 & 5.0 \\
\hline \multicolumn{7}{|l|}{ Sources: C.A.R. authorities; and IMF staff estimates. } \\
\hline \multicolumn{7}{|c|}{$\begin{array}{l}{ }^{2} \text { Domestic revenue, which excludes foreign grants and divestiture receipts (see the Technical Memorandum of Understanding, TMU, fo } \\
{ }^{3} \text { The domestic primary balance is defined as the difference between government domestic revenue and government total expenditure, } \\
\text { less all interest payments and externally-financed capital expenditure. } \\
{ }^{4} \text { The floor will be adjusted downward by } 50 \text { percent of any higher-than-programmed grants at the test date. }\end{array}$} \\
\hline $\begin{array}{l}{ }^{5} \text { Net domestic financing covers all bank and nonbank finan } \\
\text { temporary shortfalls in programmed grants (see the TMU) } \\
\text { ) } \\
{ }^{6} \text { Contracted or guaranteed by the government (see the TMU } \\
{ }^{7} \text { These objectives will be monitored continuously. } \\
{ }^{8} \text { Total spending on health, education, rural development, an } \\
{ }^{9} \text { The floor will be adjusted upward by } 50 \text { percent of any high }\end{array}$ & $\begin{array}{l}\text { including bonds issu } \\
\text { cial affairs, including }\end{array}$ & in the regional market. & fe floor will be adjusted & fard by 100 percent in & ases of & \\
\hline
\end{tabular}


Table I.2. Central African Republic: Prior Actions and Structural Benchmarks, 2012-13

\begin{tabular}{l}
\hline Measures \\
\hline Public Financial Management \\
Prepare an annual cash flow plan with a monthly \\
breakdown taking into account the fiscal targets \\
included in the 2012 program and the budget law for \\
each year of the program.
\end{tabular}

Adopt a credible plan to clear the audited stock of domestic payments arrears with transparent criteria communicated to all parties concerned.

Limit recourse to exceptional payment procedures for current expenditure, excluding wages and finance charges, for the three remaining quarters of 2012 to 5 percent at most.

Report monthly execution data regarding externallyfinanced capital expenditure to the Ministry of Finance.

Create a mechanism for data sharing between the Treasury and Budget Directorate so as to facilitate the preparation of complete, detailed budget execution reports.

\section{Revenue administration and tax policy}

Make the pilot taxation site for medium-sized enterprises functional.

Update and secure the single taxpayer identification number (TIN, tax and customs administrations).

Adjust petroleum product prices in full conformity with the 2011 automatic price setting formula and regularly apply the formula.

\section{Debt management}

Adopt all the legislative texts governing the functioning of the National Public Debt Committee (CNDP) to ensure rigorous monitoring of government borrowing, the issuance of government securities, and loan guarantees.

\section{Management of natural resource}

Review current mining legislation and align it with international best practice.
Timeline

Prior action

(done). Annual

structural

benchmark

(SB)

March 2013.

Quarterly (SB)

September

2012, and

monthly

thereafter

July 2012

End-June 2013

(SB)

End-March

2013 (SB)

Prior action

(done).

Monthly (SB)

End-September 2012 (SB)

End-September 2013 (SB)

\section{Macroeconomic Rationale}

Strengthen budget execution.

Restore confidence in the government's signature and reduce total domestic debt.

Improve compliance with established budget procedures.

Include capital expenditure in the budget reporting system.

Strengthen the transparency, timeliness, and accuracy of budget reports and create the conditions for effective liquidity management.

Broaden the tax base and improve the efficiency of the tax system.

Improve taxpayer identification and strengthen tax compliance.

Insulate the budget from the risk of fluctuation in petroleum product prices; create the fiscal space needed to mitigate the social impact of change in petroleum product prices.

Strengthen the capacity for active debt management and monitoring of debt sustainability based on the outcome of the Evaluation of the Debt Management Plan.

Strengthen natural resource management and maximize benefit to the population. 


\section{APPENDIX I \\ ATtaChment II \\ TransLATEd From FrenCH \\ Central African Republic \\ TECHNICAL MEMORANDUM OF UNDERSTANDING}

Bangui, June 11, 2012

\section{INTRODUCTION}

1. This Technical Memorandum of Understanding (TMU) defines the performance criteria for the first year of the program supported by the Extended Credit Facility (ECF) arrangement (from June 25, 2012 to June 24, 2013). It also sets out the frequency and deadlines for data reporting to the staff of the International Monetary Fund (IMF) for program monitoring purposes. Unless otherwise indicated, all the performance criteria and indicative targets will be assessed on the basis of cumulative flows from the beginning of the year.

\section{Program Assumptions}

2. Program exchange rates. For the purposes of this TMU, the value of transactions denominated in foreign currencies will be converted into CFA francs (CFAF), the currency of the Central African Republic (C.A.R.), on the basis of the program exchange rates. The key exchange rates are shown below. ${ }^{1}$

\begin{tabular}{|lc|}
\hline CFAF/US\$ & 506.96 \\
CFAF/euro & 655.96 \\
CFAF/SDR & 778.32 \\
\hline
\end{tabular}

3. Oil price assumption. The program assumes an average price of a barrel of oil of US\$114 in 2012. ${ }^{2}$

\footnotetext{
${ }^{1}$ Exchange rates as of December 31, 2011.

2 April 2012 WEO.
} 


\section{DEFINITIONS}

4. Unless otherwise indicated, the government is understood to mean the central government of the C.A.R. and does not include any local governments, the central bank, or any public entity with separate legal personality (i.e., enterprises wholly or partially owned by the government) that are not included in the table on government financial operations (Tableau des opérations financières de l'Etat-TOFE).

5. Definition of debt. The definition of debt is set out in point 9 of Decision No. 6230(79/140) of the Executive Board of the IMF, as amended on August 31, 2009 by decision No. 14416-(09/91) of the Executive Board:

(a) "Debt" is understood to mean a current, i.e., not contingent, liability, created under a contractual arrangement through the provision of value in the form of assets (including currency) or services, and which requires the obligor to make one or more payments in the form of assets (including currency) or services, according to a specific schedule; these payments will discharge the obligor of the principal and/or interest liabilities incurred under the contract. Debts can take a number of forms, the primary ones being as follows:

i. loans, i.e., advances of money to the obligor by the lender made on the basis of an undertaking that the obligor will repay the funds in the future (including deposits, bonds, debentures, commercial loans, and buyers' credits) and temporary exchanges of assets that are equivalent to fully collateralized loans, under which the obligor is required to repay the funds, and usually pay interest, by repurchasing the collateral from the buyer in the future (such as repurchase agreements and official swap arrangements);

ii. suppliers' credits, i.e., contracts where the supplier permits the obligor to defer payments until sometime after the date on which the goods are delivered or services are provided; and

iii. leases, i.e., arrangements under which property is provided that the lessee has the right to use for one or more specified period(s) of time that are usually shorter than the total expected service life of the property, while the lessor retains the title to the property. For the purpose of this guideline, the debt is the present value (at the inception of the lease) of all lease payments expected to be made during the period of the agreement, excluding those payments necessary for the operation, repair, or maintenance of the property.

(b) Under the definition of debt set out above, arrears, penalties, and judicially awarded damages arising from the failure to make payment under a contractual obligation that 
constitutes debt are debt. Failure to make payment on an obligation that is not considered debt under this definition (e.g., payment on delivery) will not give rise to debt.

(c) "Domestic debt" is defined as debt denominated in CFA francs unless it is contracted with another member state of the Central African Economic and Monetary Community (CEMAC).

(d) "External debt" is defined as debt denominated in a currency other than the CFA franc and debt contracted with another member state of the CEMAC.

6. Guaranteed debt. The guaranteeing of a debt by the government is understood to be an explicit legal obligation to service a debt in the event of nonpayment by the borrower (by means of settlements in cash or in kind).

7. Concessional debt. A debt is concessional if it includes a grant element of at least 35 percent, ${ }^{3}$ the grant element of a debt being the difference between the present value of debt and its nominal value, expressed as a percentage of the nominal value of the debt. The present value of debt at the time of its contracting is calculated by discounting the future stream of payments of debt service due on this debt. ${ }^{4}$ The discount rates used for this purpose are the currency specific commercial interest reference rates (CIRRs) for each currency as published by the Organization for Economic Cooperation and Development (OECD). ${ }^{5}$ For debt with a maturity of at least 15 years, the ten-year-average CIRR will be used to calculate the present value of debt and, hence, its grant element. For debt with a maturity of less than 15 years, the six-month average CIRR will be used. To both the ten-year and six-month averages, the same margins for differing repayment periods as those used by the OECD need to be added $(0.75$ percent for repayment periods of less than 15 years, 1 percent for repayment periods of 15 years to 19 years, 1.15 percent for repayment periods of 20 years to 29 years, and 1.25 percent for repayment periods of 30 years or more).

\footnotetext{
3 The following link to the IMF website leads to a tool for the calculation of the grant element for a broad range of financing packages: http://www.imf.org/external/np/pdr/conc/calculator.

${ }^{4}$ The calculation of concessionality takes account of all aspects of the loan contract, including the maturity, the grace period, the schedule, the commitment fees, and the management costs.

${ }^{5}$ In the case of loans denominated in foreign currencies for which the OECD does not calculate the CIRR, calculation of the grant element must be based on the composite CIRR (weighted average) for the currencies included in the SDR.
} 


\section{Performance Criteria And Quantitative Benchmarks}

\section{A. Performance Criteria}

\section{Floor for total domestic revenue of the government}

8. Domestic revenue of the government includes the revenues shown in the TOFE, specifically tax and nontax revenue, earmarked revenue, checks for project-related customs duties, and withholdings from the wages and salaries of government employees, and excludes foreign grants and the proceeds of privatizations or government divestments. The performance criterion (PC) on government domestic revenue will be set at CFAF 66.6 billion and CFAF 128.1 billion as of end-June and end-December 2012, respectively. The indicative targets (ITs) for end-September 2012 and end-March 2013 will be CFAF 96.1 and 34.5 billion, respectively.

\section{Floor for the domestic primary fiscal balance}

9. The domestic primary fiscal balance, on a commitment basis, is defined as the difference between domestic revenue and expenditure of the government, excluding interest payments and externally financed capital expenditure. The PC on the domestic primary fiscal balance will be set at CFAF 6.2 billion and CFAF 6.3 billion at end-June and endDecember 2012, respectively. The QB for end-September 2012 and end-March 2013 will be CFAF 6.0 and 4.0 billion, respectively.

Adjuster. If external budgetary grants received exceed the program forecasts as of the date of assessment, the floor for the primary fiscal balance will be adjusted downward by the equivalent of 50 percent of the excess grants.

\section{Ceiling on net domestic financing of the government}

10. Net domestic financing of the government is defined as the sum of: (i) the net government position vis-à-vis the banking system as defined below; (ii) the amount of issues of government securities (net of redemptions) subscribed by individuals or legal entities outside the banking system or nonresident banks domiciled in the CEMAC; and (iii) privatization proceeds or exceptional revenue recorded "above the line."

11. The net government position is defined as the balance between the debts and claims of the government vis-à-vis the central bank and commercial banks. The scope of the net government position is that used by the Bank of Central African States (BEAC) and is in keeping with general IMF practice in this area. It implies a definition of government that is broader than the one indicated in the TMU ( $(4)$ and includes local governments and some projects and administrative public entities. Government claims include the CFA franc cash 
balance, postal checking accounts, customs duty bills, and all deposits with the BEAC and commercial banks of public entities with the exception of industrial or commercial public entities (EPICs) and government corporations, which are excluded from the calculation. The government debt to the banking system includes all debts vis-à-vis these same financial institutions.

Adjuster. If external budgetary grants received are below program forecasts or temporarily delayed, the ceiling on net domestic financing of the government will be adjusted upward by 100 percent of the grant shortfall. A grant is deemed to be temporarily delayed if the payment of said grant takes place later in the fiscal year during which it is programmed.

\section{Ceiling on nonconcessional external debt contracted or guaranteed by the government}

12. This PC applies not only to debt as defined in the TMU ( $₫ 5)$, but also to liabilities contracted or guaranteed by the government (including lease-purchase contracts) for which no funds have been received. This PC also applies to private debt guaranteed by the government, which constitutes a contingent liability for the government. As indicated in paragraph 5 of the TMU, external debt excludes bonds and treasury bills denominated in CFA francs issued on the CEMAC regional market. Nonconcessional debt is debt other than concessional debt defined in paragraph 7. This PC applies here and also applies to short-term debts (with an initial maturity of one year or less) and to medium- and long-term debts (with an initial maturity of more than one year). This PC applies on a continuous basis. Normal import-related credits are excluded from this PC. "Normal import-related credit" is understood to be self-liquidating credit where the proceeds from sales of imports are used to retire the debt.

13. The term "government" used for purposes of this performance criterion and for the performance criterion on short-term external debt newly contracted or guaranteed by the government includes the government as defined in paragraph 4 of the TMU, local governments, and all public enterprises, including administrative public entities (EPA), scientific and technical public entities, professional public entities, and entities jointly owned by the government of the C.A.R. with the government(s) of another country or countries.

14. No nonconcessional loans will be contracted or guaranteed by the government. During program reviews (after approval by the Executive Board of the IMF), changes may be made to the ceiling for specific investment projects, the financial viability and profitability of which have been evaluated and approved by the World Bank or the African Development Bank, and on condition that the loan does not significantly exacerbate debt vulnerabilities according to the debt sustainability analysis prepared jointly by the staff of the World Bank and the IMF. 
15. The government also undertakes not to contract or guarantee any external loans during the program implementation period without first having determined their concessionality with IMF staff.

\section{Non-accumulation of new external payment arrears by the government}

16. External payment arrears are defined as payments in respect of the external debt of the government or guaranteed by the government that are due and not paid by the government at the maturity specified in the contract. The definitions of debt and external debt indicated in paragraph 5 and of government indicated in paragraph 4 apply here.

17. The government undertakes not to accumulate external payment arrears with the exception of arrears relating to debt that is the subject of renegotiation or rescheduling. This performance criterion applies on a continuous basis.

\section{B. Indicative Targets}

\section{Floor for priority poverty reduction expenditures}

18. Priority poverty reduction expenditures are defined as the sum of expenditures by the Ministry of Social Affairs, National Solidarity and the Family; the Ministry of National Education, Higher Education and Research; and the Ministry of Public Health, Population and AIDS Prevention, including expenditures for the year under way and repayment of arrears for these sectors. They exclude capital expenditures financed by external technical and financial partners in the form of projects.

\section{Floor for the reduction of domestic payments arrears of the government}

19. The reduction of domestic payments arrears measures the change in the total stock of arrears during the program period. Domestic payments arrears are defined as domestic payments due and not paid by the government after a 90-day grace period, unless the terms and conditions for settlement specify a longer grace period. The DDP and Treasury record and update the data concerning the accumulation of domestic payments arrears and their reduction. The definitions of debt and domestic debt specified in paragraph 5 and of government specified in paragraph 4 apply here. The stock of domestic payments arrears was CFAF 123 billion as of end-December 2011; this amount will be the subject of an audit conducted with EU support.

Adjuster. If external budgetary grants received are higher than program forecasts as of the date of assessment, the floor for the reduction of domestic payments arrears will be adjusted upward by the equivalent of 50 percent of the excess grants. 


\section{Non-accumulation of new domestic payment arrears by the government}

20. The government undertakes not to accumulate domestic payment arrears as defined in 919. This PC applies on a continuous basis.

\section{Prior actions And Structural Benchmarks}

\section{A. Prior Actions}

\section{Annual cash-flow plan broken down by month (also SB)}

21. The annual cash-flow plan approved on April 30, 2012 is based on the TOFE for the 2012 program, broken down by quarter and by month. It establishes the cash flow programming for the government by including all elements affecting the government's cash flow, including, in particular, anticipated revenue and revenue forecast in the budget in accordance with the 2012 program objectives. According to the provisions governing the monitoring agencies established by the government, the monthly plans will be used by the Budget Management Monitoring Committee (CSGB) to set ceilings on commitments during its bimonthly meetings; the reports of the CSGB will be shared with IMF staff for regular follow-up.

\section{Adjustments in domestic petroleum prices}

22. The government adjusted domestic petroleum prices in June 2012 and undertakes to adjust prices monthly ( $(29)$.

\section{B. Structural Benchmarks}

\section{Plan for the clearance of domestic payments arrears}

23. Following the EU audit of domestic payments arrears, the government will adopt a plan for clearing these arrears, including clearly defined repayment conditions and transparent criteria communicated to all parties concerned.

\section{Ceiling on the use of exceptional procedures}

24. Exceptional procedures are understood to mean recourse to cash payment orders (OP-Caisse) and budgetary payment orders (OP-Budget) in the execution of the government budget. The ceiling on recourse to these exceptional procedures during the period April to December 2012 will be set at CFAF 2.8 billion, or 5 percent of total expenditures, excluding wages, finance charges, and externally-financed investments during the last three quarters of 2012. This SB will be monitored quarterly. 


\section{Data reporting on execution of the capital budget}

25. Data on the execution of the capital budget must be reported to the Ministry of Finance and Budget by the beginning of June 2012 and monthly thereafter. These data will be shared with IMF staff for follow up.

\section{Data sharing mechanism}

26. A mechanism for data sharing between the Treasury and the DGB will be set up to facilitate the preparation of complete, detailed reports on budget execution by June 2012, which will be communicated to IMF staff.

\section{Pilot taxation center for medium-sized enterprises}

27. The government undertakes to provide the necessary resources to make the pilot taxation center for medium-sized enterprises operational by June 2013.

\section{Single taxpayer identification number}

28. The single identification number is the number common to customs and taxation for purposes of crosschecking of the data of these two administrations. It should be made more reliable and secure by the introduction of a lockout system.

\section{Use of the automatic price-setting formula for petroleum products}

29. The automatic retail price-setting formula for petroleum products should be applied monthly for full pass-through of changes in international oil prices and all costs in the price structure approved in 2008, including customs duties, the specific tax on petroleum products (TSPP), VAT at the normal rate, the single tax on petroleum products (TUPP), and distribution margins so as to avoid any subsidies (negative TUPP or government support for the sector). The periodic monthly adjustments will regularly reflect changes in international oil prices and protect forecasts of revenues expected from the taxation of petroleum products included in the 2012 budget law amounting to a total of CFAF 17.9 billion.

\section{Adoption of legislative texts governing the operation of the CNDP}

30. By September 30, 2012, the government will have validated all laws and regulations governing the operation of the CNDP in order to make it fully operational.

\section{Framework for natural resource management}

31. The government will review the existing legislation (mining code) and align it with international best practice. 


\section{DATA REPORTING TO THE IMF}

32. Quantitative data on the PCs and other indicative targets will be reported to the IMF staff in accordance with the schedule set out in Table I.3. In addition, any changes to the data will be reported as soon as possible. The government undertakes to consult the IMF staff on any information or data not specifically discussed in this TMU that are relevant for the assessment and monitoring of the attainment of the program objectives. 


\section{Table I.3. Central African Republic-Data Reporting to the IMF under the ECF Arrangement}

\begin{tabular}{|c|c|}
\hline Description of data & Deadline \\
\hline $\begin{array}{l}\text { Quarterly report assessing the quantitative indicators and } \\
\text { structural measures (relating, in particular, to the structural } \\
\text { benchmarks; see Table } 2 \text { of the MEFP), along with supporting } \\
\text { documentation. }\end{array}$ & $\begin{array}{l}\text { Within four weeks after the end of } \\
\text { each quarter. }\end{array}$ \\
\hline $\begin{array}{l}\text { Monetary survey, monthly accounts of the central bank and } \\
\text { commercial banks. }\end{array}$ & $\begin{array}{l}\text { Within four weeks after the end of } \\
\text { each month. }\end{array}$ \\
\hline Table of monthly cash flow operations. & $\begin{array}{l}\text { Within } 10 \text { days after the end of each } \\
\text { month. }\end{array}$ \\
\hline Fiscal reporting table (TOFE). & $\begin{array}{l}\text { Within four weeks after the end of } \\
\text { each month. }\end{array}$ \\
\hline $\begin{array}{l}\text { Monthly total of domestic payments arrears on goods and } \\
\text { services and wages, including unpaid pensions and bonuses. }\end{array}$ & $\begin{array}{l}\text { Within four weeks after the end of } \\
\text { each month. }\end{array}$ \\
\hline End-of-period stock of external debt. & $\begin{array}{l}\text { Within four weeks after the end of } \\
\text { each month. }\end{array}$ \\
\hline $\begin{array}{l}\text { Breakdown of expenditure included in the TOFE (goods and } \\
\text { services, wages, interest, etc.). }\end{array}$ & $\begin{array}{l}\text { Within four weeks after the end of } \\
\text { each quarter. }\end{array}$ \\
\hline $\begin{array}{l}\text { Summary table of real expenditure in the priority sectors, } \\
\text { specifically health, education and security. }\end{array}$ & $\begin{array}{l}\text { Within four weeks after the end of } \\
\text { each quarter. }\end{array}$ \\
\hline $\begin{array}{l}\text { Breakdown of current and capital expenditure, both } \\
\text { domestically and externally financed. }\end{array}$ & $\begin{array}{l}\text { Within four weeks after the end of } \\
\text { each quarter. }\end{array}$ \\
\hline $\begin{array}{l}\text { Breakdown of revenue by institution and economic } \\
\text { classification. }\end{array}$ & $\begin{array}{l}\text { Within four weeks after the end of } \\
\text { each quarter. }\end{array}$ \\
\hline $\begin{array}{l}\text { Revenue and expenditure offset against each other without cash } \\
\text { settlements (by type of expenditure and revenue). }\end{array}$ & $\begin{array}{l}\text { Within four weeks after the end of } \\
\text { each quarter. }\end{array}$ \\
\hline $\begin{array}{l}\text { Breakdown of debt service and external arrears, in particular by } \\
\text { interest and principal and by main creditors. }\end{array}$ & $\begin{array}{l}\text { Within four weeks after the end of } \\
\text { each month. }\end{array}$ \\
\hline $\begin{array}{l}\text { Amount of new concessional and nonconcessional external } \\
\text { debt contracted or guaranteed by the government. }\end{array}$ & $\begin{array}{l}\text { Within four weeks after the end of } \\
\text { each month. }\end{array}$ \\
\hline $\begin{array}{l}\text { Actual disbursements for projects and programs benefiting } \\
\text { from foreign financial aid and external debt relief granted by } \\
\text { external creditors (including the date, amount and creditor). }\end{array}$ & $\begin{array}{l}\text { Within four weeks after the end of } \\
\text { each quarter }\end{array}$ \\
\hline
\end{tabular}




\section{APPENDIX II \\ Central African Republic \\ UPDATED DEbT SUSTAINABILITY ANALYSIS USING THE LOW-INCOME COUNTRY FRAMEWORK}

This appendix updates the debt sustainability analysis (DSA) originally presented in May 2010. Debt relief under the enhanced Heavily Indebted Poor Countries (HIPC) Initiative and the Multilateral Debt Relief Initiative (MDRI) at the completion point in June 2009 has alleviated Central African Republic's (C.A.R.) debt burden and the economy continues to face a moderate risk of debt distress.

C.A.R.'s total public debt, including domestic arrears increased markedly, reaching 42.2 percent of GDP in 2011. This is, well above the projected level of 27 percent in the 2010 DSA. The debt dynamic in 2010-11 is driven by arrears accumulation on both domestic and external debt and a steady rise in external borrowing from Non-Paris Club members to finance infrastructure projects and social programs. In 2010-11, the C.A.R. contracted concessional loans from India and China for US\$52.3 million (2.4 percent of GDP). Accumulation of arrears on external debt amounted US\$9.8 million ( 0.5 percent of GDP) of which US\$2 million is due to one Paris Club creditor (France) and US\$0.7 million to the European Investment Bank, and the balance to Non-Paris Club creditors that have not yet signed bilateral agreements with C.A.R. Domestic debt accumulation amounted to 3.6 percent of GDP.

The macroeconomic assumptions in the near to medium term for the updated analysis are broadly in line with the previous DSA. Growth is expected to accelerate to around 5 percent per annum on average on the back of scaled-up infrastructures financed by concessional external loans and foreign direct investment inflows. The external current account is projected to remain steady as imports related to oil and infrastructure projects would offset rising exports. The fiscal stance is expected to improve on account of increased revenue mobilization and strong budget execution. From 2021 onwards, major mining projects (oil and uranium) would come on stream, boosting growth and government revenue.

As in the full DSA, this update suggests that C.A.R. continues to face a "moderate risk of debt distress". Although somewhat higher compared to last year exercise, all baseline debt indicators remain below the thresholds with stable downward trends, but the debt position could still be vulnerable to the most extreme shock to terms of trade and exports, yielding the highest ratio by 2022. The C.A.R. is classified as having "lower debt vulnerabilities and lower capacity" under the Fund's debt limits framework and therefore should rely on concessional borrowing. Also, World Bank's country policy and institutional assessment rating for C.A.R. averaged 2.6 in the last three years, making C.A.R. a weak performer. 
Figure II.1. Central African Republic: Indicators of Public and PubliclyGuaranteed External Debt Under Alternatives Scenarios, 2012-321
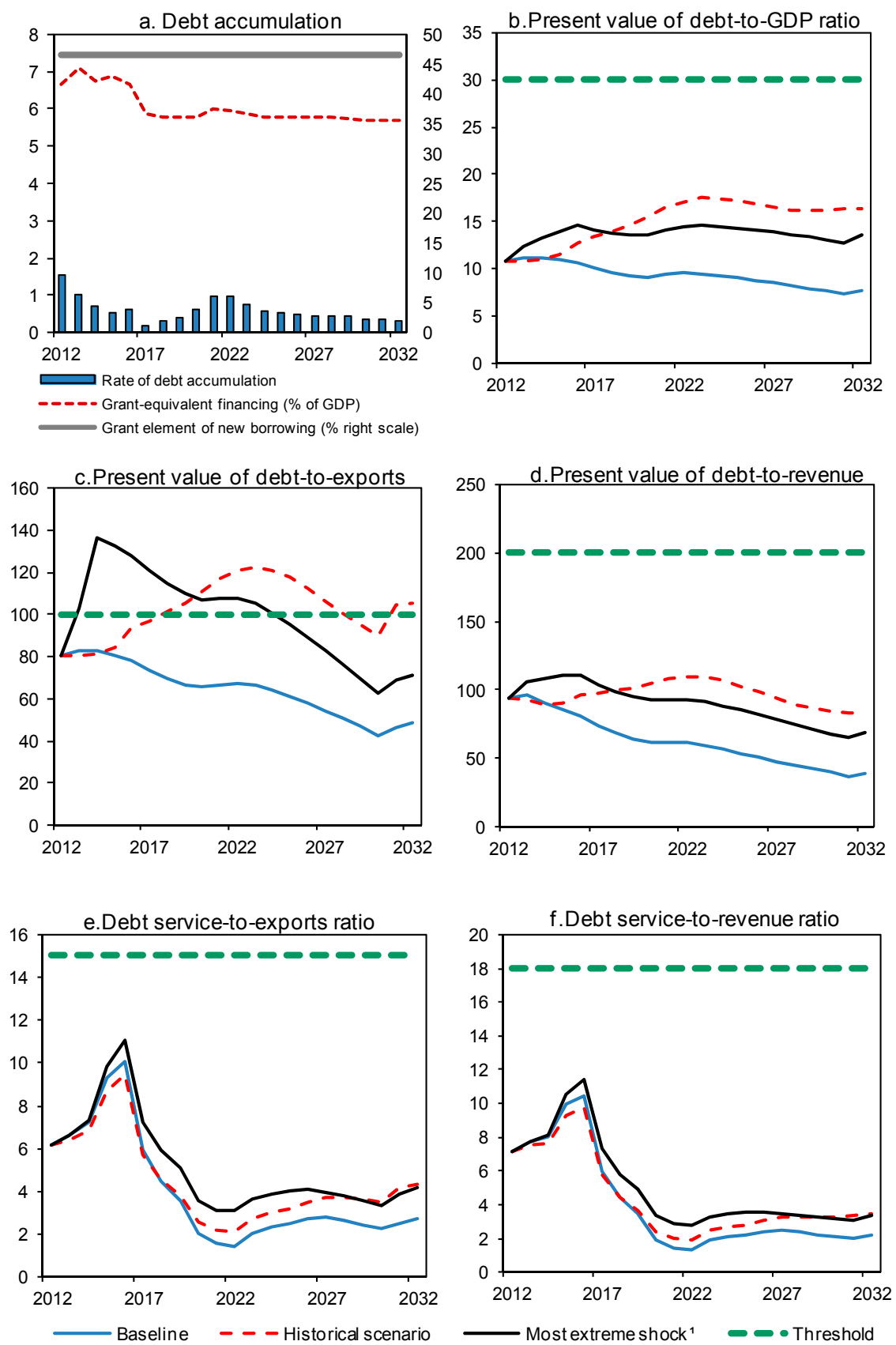

Sources: C.A.R. authorities; and IMF estimates and projections.

1 The most extreme stress test is the test that yields the highestratio in 2022. In figures b., d.,

e., and f. it corresponds to a terms-of-trade shock; in c. to an exports shock. 
Figure II.2. Central African Republic: Indicators of Public Debt Under Alternative Scenarios, 2012-32 ${ }^{1}$
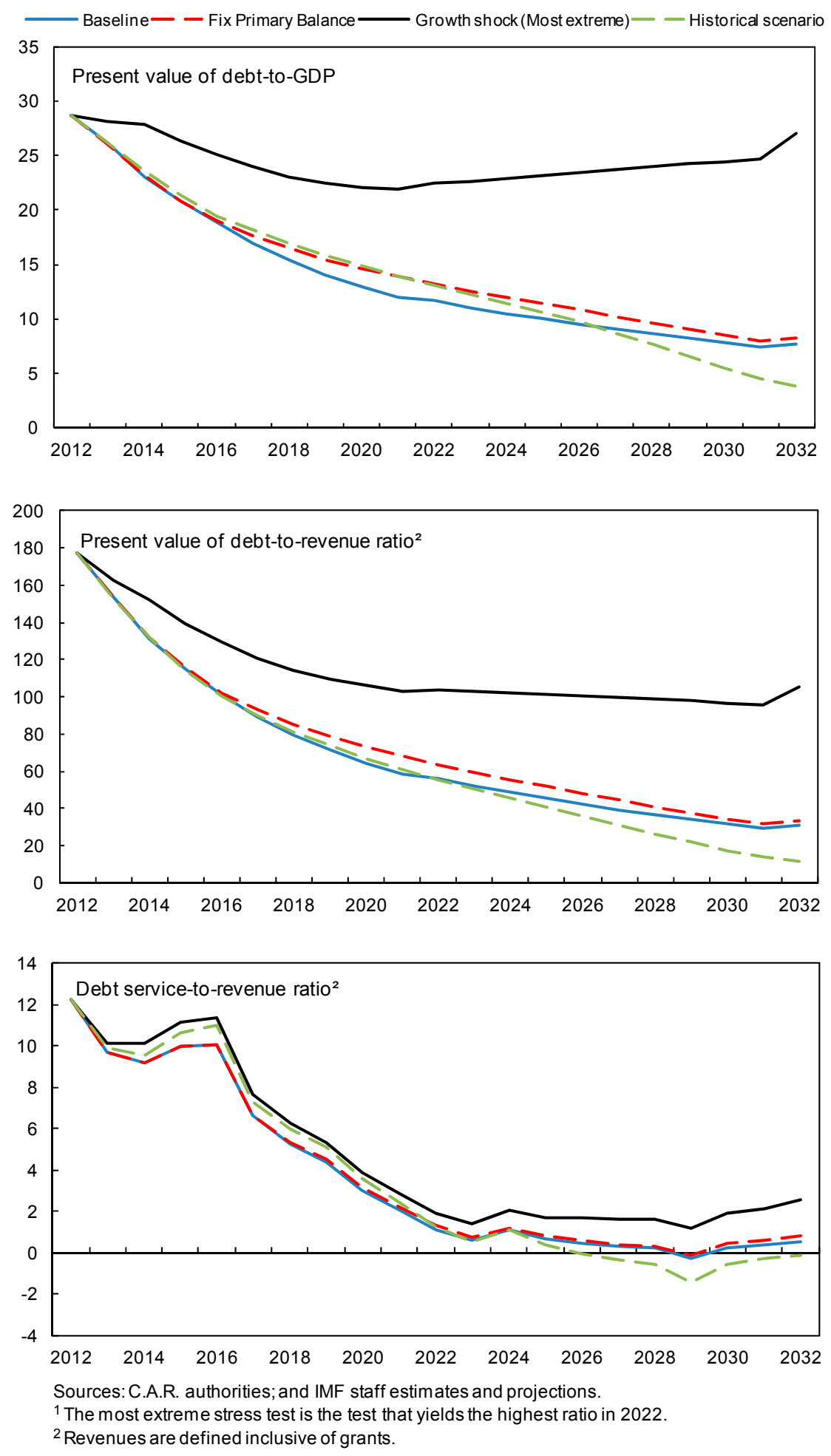


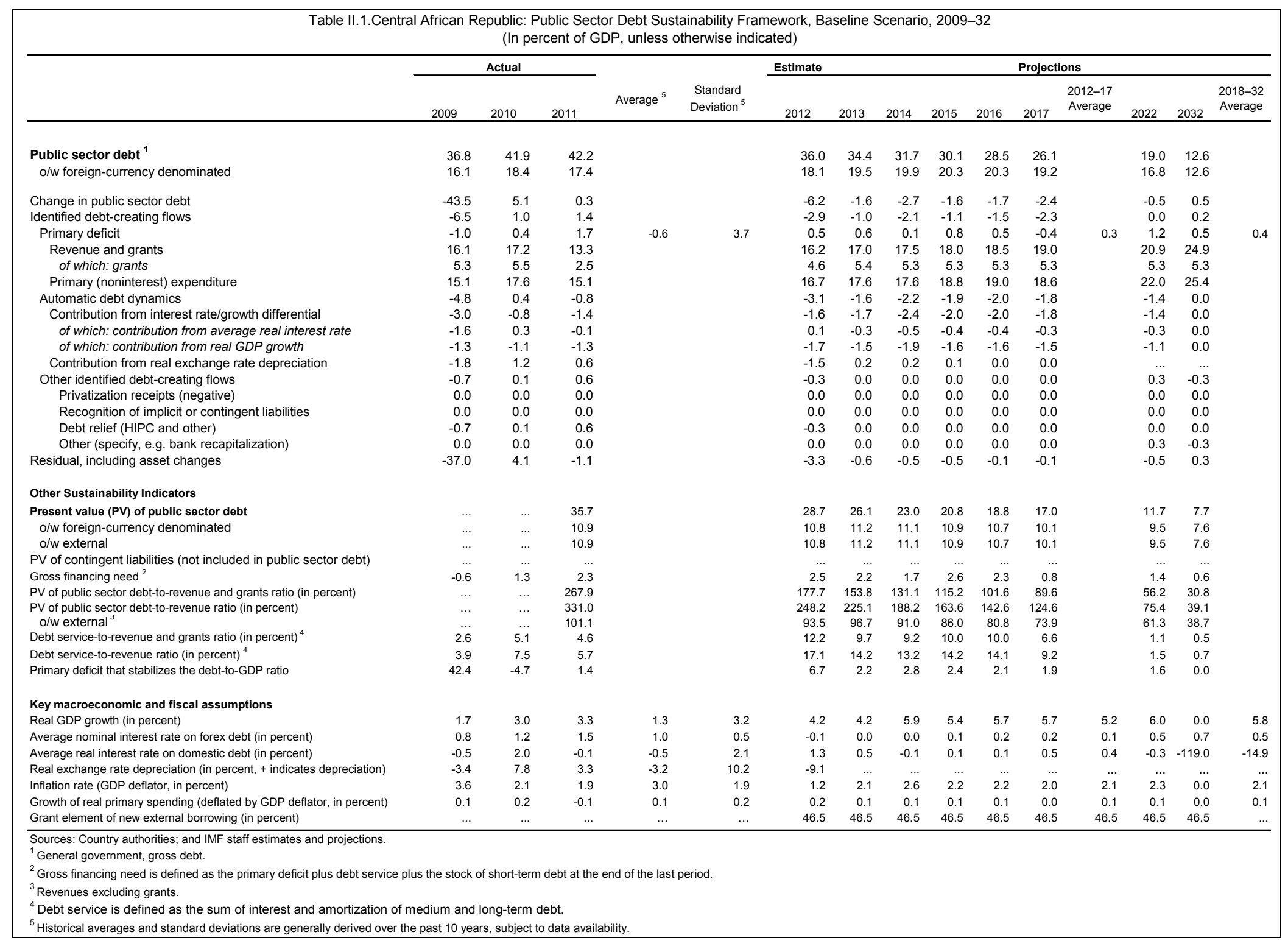


Table II.2.Central African Republic: Sensitivity Analysis for Key Indicators of Public Debt, 2012-32

\begin{tabular}{|c|c|c|c|c|c|c|c|c|}
\hline & \multicolumn{8}{|c|}{ Projections } \\
\hline & 2012 & 2013 & 2014 & 2015 & 2016 & 2017 & 2022 & 2032 \\
\hline \multicolumn{9}{|c|}{ Present value of debt-to-GDP ratio } \\
\hline Baseline & 29 & 26 & 23 & 21 & 19 & 17 & 12 & 8 \\
\hline \multicolumn{9}{|l|}{ A. Alternative scenarios } \\
\hline A1. Real GDP growth and primary balance are at historical averages & 29 & 26 & 24 & 21 & 19 & 18 & 13 & 4 \\
\hline A2. Primary balance is unchanged from 2012 & 29 & 26 & 23 & 21 & 19 & 18 & 13 & 8 \\
\hline A3. Permanently lower GDP growth ${ }^{1}$ & 29 & 26 & 23 & 21 & 20 & 18 & 15 & 21 \\
\hline \multicolumn{9}{|l|}{ B. Bound tests } \\
\hline B1. Real GDP growth is at historical average minus one standard deviations in 2013-2014 & 29 & 28 & 28 & 26 & 25 & 24 & 23 & 27 \\
\hline B2. Primary balance is at historical average minus one standard deviations in $2013-2014$ & 29 & 28 & 26 & 24 & 22 & 20 & 14 & 9 \\
\hline B3. Combination of B1-B2 using one half standard deviation shocks & 29 & 28 & 27 & 25 & 23 & 22 & 20 & 22 \\
\hline B4. One-time 30 percent real depreciation in 2013 & 29 & 30 & 26 & 23 & 20 & 18 & 12 & 7 \\
\hline B5. 10 percent of GDP increase in other debt-creating flows in 2013 & 29 & 32 & 28 & 26 & 24 & 22 & 16 & 11 \\
\hline \multicolumn{9}{|c|}{ Present value of debt-to-revenue ratio ${ }^{2}$} \\
\hline Baseline & 178 & 154 & 131 & 115 & 102 & 90 & 56 & 31 \\
\hline \multicolumn{9}{|l|}{ A. Alternative scenarios } \\
\hline A1. Real GDP growth and primary balance are at historical averages & 178 & 153 & 132 & 114 & 100 & 90 & 55 & 12 \\
\hline A2. Primary balance is unchanged from 2012 & 178 & 154 & 132 & 116 & 102 & 93 & 63 & 33 \\
\hline A3. Permanently lower GDP growth ' & 178 & 155 & 133 & 118 & 106 & 96 & 72 & 81 \\
\hline \multicolumn{9}{|l|}{ B. Bound tests } \\
\hline B1. Real GDP growth is at historical average minus one standard deviations in 2013-2014 & 178 & 163 & 152 & 140 & 130 & 121 & 104 & 105 \\
\hline B2. Primary balance is at historical average minus one standard deviations in $2013-2014$ & 178 & 162 & 149 & 132 & 117 & 104 & 67 & 35 \\
\hline B3. Combination of B1-B2 using one half standard deviation shocks & 178 & 161 & 147 & 133 & 123 & 113 & 92 & 87 \\
\hline B4. One-time 30 percent real depreciation in 2013 & 178 & 176 & 147 & 126 & 108 & 94 & 57 & 28 \\
\hline B5. 10 percent of GDP increase in other debt-creating flows in 2013 & 178 & 187 & 162 & 144 & 128 & 115 & 76 & 44 \\
\hline \multicolumn{9}{|c|}{ Debt service-to-revenue ratio ${ }^{2}$} \\
\hline Baseline & 12 & 10 & 9 & 10 & 10 & 7 & 1 & 1 \\
\hline \multicolumn{9}{|l|}{ A. Alternative scenarios } \\
\hline A1. Real GDP growth and primary balance are at historical averages & 12 & 10 & 10 & 11 & 11 & 7 & 1 & 0 \\
\hline A2. Primary balance is unchanged from 2012 & 12 & 10 & 9 & 10 & 10 & 7 & 1 & 1 \\
\hline A3. Permanently lower GDP growth ${ }^{1}$ & 12 & 10 & 9 & 10 & 10 & 7 & 1 & 2 \\
\hline \multicolumn{9}{|l|}{ B. Bound tests } \\
\hline B1. Real GDP growth is at historical average minus one standard deviations in $2013-2014$ & 12 & 10 & 10 & 11 & 11 & 8 & 2 & 3 \\
\hline B2. Primary balance is at historical average minus one standard deviations in $2013-2014$ & 12 & 10 & 9 & 10 & 10 & 7 & 1 & 1 \\
\hline B3. Combination of B1-B2 using one half standard deviation shocks & 12 & 10 & 10 & 11 & 11 & 7 & 2 & 2 \\
\hline B4. One-time 30 percent real depreciation in 2013 & 12 & 11 & 12 & 13 & 13 & 9 & 2 & 2 \\
\hline B5. 10 percent of GDP increase in other debt-creating flows in 2013 & 12 & 10 & 10 & 11 & 10 & 7 & 1 & 1 \\
\hline
\end{tabular}

Sources: Country authorities; and IMF staff estimates and projections.

${ }^{1}$ Assumes that real GDP growth is at baseline minus one standard deviation divided by the square root of the length of the projection period.

${ }^{2}$ Revenues are defined inclusive of grants. 
Table II.3b.Central African Republic: Sensitivity Analysis for Key Indicators of Public and Publicly-Guaranteed External Debt, 2012-32 (Percent)

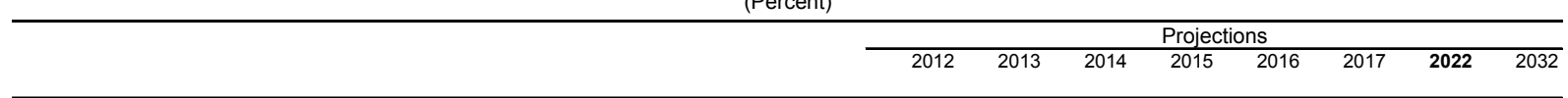

Present value of debt-to GDP ratio

Baseline

A. Alternative Scenarios

A1. Key variables at their historical averages in 2012-2032

A2. New public sector loans on less favorable terms in $2012-2032^{2}$

\section{B. Bound Tests}

B1. Real GDP growth at historical average minus one standard deviation in 2013-2014

B2. Export value growth at historical average minus one standard deviation in 2013-2014 ${ }^{3}$

B3. US dollar GDP deflator at historical average minus one standard deviation in 2013-2014

B4. Net non-debt creating flows at historical average minus one standard deviation in 2013-2014 ${ }^{4}$

B5. Combination of B1-B4 using one-half standard deviation shocks

B6. One-time 30 percent nominal depreciation relative to the baseline in $2013^{5}$
11

11

11

12

12

1112

1111

$11 \quad 13$

$11 \quad 13$

Present value of debt-to-exports ratio

\section{Baseline}

A. Alternative Scenarios

A1. Key variables at their historical averages in $2012-2032$

A2. New public sector loans on less favorable terms in $2012-2032^{2}$

B. Bound Tests

B1. Real GDP growth at historical average minus one standard deviation in 2013-2014

B2. Export value growth at historical average minus one standard deviation in 2013-2014 ${ }^{3}$

B3. US dollar GDP deflator at historical average minus one standard deviation in 2013-2014

B4. Net non-debt creating flows at historical average minus one standard deviation in 2013-2014 ${ }^{4}$

B5. Combination of B1-B4 using one-half standard deviation shocks

B6. One-time 30 percent nominal depreciation relative to the baseline in $2013^{5}$

$\begin{array}{rrrrrrrr}81 & 83 & 82 & 80 & 78 & 73 & \mathbf{6 7} & 49 \\ & & & & & & & \\ 81 & 80 & 81 & 85 & 94 & 97 & \mathbf{1 2 1} & 105 \\ 81 & 91 & 98 & 103 & 106 & 103 & \mathbf{1 0 3} & 86 \\ & & & & & & & \\ & & & & & & & \\ 81 & 83 & 82 & 80 & 78 & 73 & \mathbf{6 7} & 48 \\ 81 & 103 & 136 & 132 & 128 & 121 & \mathbf{1 0 7} & 71 \\ 81 & 83 & 82 & 80 & 78 & 73 & \mathbf{6 7} & 48 \\ 81 & 97 & 110 & 107 & 103 & 97 & \mathbf{8 6} & 55 \\ 81 & 103 & 130 & 126 & 122 & 115 & \mathbf{1 0 1} & 65 \\ 81 & 83 & 82 & 80 & 78 & 73 & \mathbf{6 7} & 48\end{array}$

Present value of debt-to-revenue ratio

Baseline

A. Alternative Scenarios

A1. Key variables at their historical averages in 2012-2032

A2. New public sector loans on less favorable terms in $2012-2032^{2}$

B. Bound Tests

B1. Real GDP growth at historical average minus one standard deviation in 2013-2014

B2. Export value growth at historical average minus one standard deviation in 2013-2014 ${ }^{3}$

B3. US dollar GDP deflator at historical average minus one standard deviation in 2013-2014

B4. Net non-debt creating flows at historical average minus one standard deviation in 2013-2014 ${ }^{4}$

B5. Combination of B1-B4 using one-half standard deviation shocks

B6. One-time 30 percent nominal depreciation relative to the baseline in $2013^{5}$
94

106

108

110

110

104

$\begin{array}{rrrrrrrr}94 & 102 & 104 & 98 & 92 & 84 & \mathbf{7 0} & 44 \\ 94 & 105 & 114 & 107 & 100 & 92 & \mathbf{7 4} & 43 \\ 94 & 97 & 93 & 88 & 83 & 76 & \mathbf{6 3} & 40 \\ 94 & 113 & 122 & 114 & 107 & 98 & \mathbf{7 8} & 44 \\ 94 & 114 & 131 & 123 & 115 & 106 & \mathbf{8 4} & 47 \\ 94 & 137 & 129 & 122 & 114 & 105 & \mathbf{8 7} & 55\end{array}$


Table II.3b.Central African Republic: Sensitivity Analysis for Key Indicators of Public and Publicly-Guaranteed External Debt, $2012-2032$ (conclued) (Percent)

Debt service-to-exports ratio

Baseline

A. Alternative Scenarios

A1. Key variables at their historical averages in 2012-2032 ${ }^{1}$

A2. New public sector loans on less favorable terms in $2012-2032^{2}$

6

\section{B. Bound Tests}

B1. Real GDP growth at historical average minus one standard deviation in 2013-2014

B2. Export value growth at historical average minus one standard deviation in 2013-2014 ${ }^{3}$

B3. US dollar GDP deflator at historical average minus one standard deviation in 2013-2014

B4. Net non-debt creating flows at historical average minus one standard deviation in 2013-2014 ${ }^{4}$

B5. Combination of B1-B4 using one-half standard deviation shocks

B6. One-time 30 percent nominal depreciation relative to the baseline in $2013^{5}$

Debt service-to-revenue ratio

\section{Baseline}

\section{A. Alternative Scenarios}

A1. Key variables at their historical averages in $2012-2032$

A2. New public sector loans on less favorable terms in $2012-2032^{2}$

\section{B. Bound Tests}

B1. Real GDP growth at historical average minus one standard deviation in 2013-2014

B2. Export value growth at historical average minus one standard deviation in 2013-2014 ${ }^{3}$

B3. US dollar GDP deflator at historical average minus one standard deviation in 2013-2014

B4. Net non-debt creating flows at historical average minus one standard deviation in 2013-2014 ${ }^{4}$

B5. Combination of B1-B4 using one-half standard deviation shocks

B6. One-time 30 percent nominal depreciation relative to the baseline in $2013^{5}$

Memorandum item

Grant element assumed on residual financing (i.e., financing required above baseline) ${ }^{6}$

$\begin{array}{rrrr}6 & 7 & 7 & \\ 6 & 8 & 10 & 13 \\ 6 & 7 & 7 & \\ 6 & 7 & 7 & 10 \\ 6 & 7 & 9 & 11 \\ 6 & 7 & 7 & \end{array}$

9
13
9
10
11
9

$\begin{array}{llll}10 & 6 & \mathbf{1} & 3 \\ 14 & 8 & \mathbf{2} & 4 \\ 10 & 6 & \mathbf{1} & 3 \\ 11 & 6 & \mathbf{2} & 3 \\ 12 & 7 & \mathbf{2} & 4 \\ 10 & 6 & \mathbf{1} & 3\end{array}$

Sources: Country authorities; and IMF staff estimates and projections.

${ }^{1}$ Variables include real GDP growth, growth of GDP deflator (in U.S. dollar terms), non-interest current account in percent of GDP, and non-debt creating flows.

${ }^{2}$ Assumes that the interest rate on new borrowing is by 2 percentage points higher than in the baseline., while grace and maturity periods are the same as in the baseline.

${ }^{3}$ Exports values are assumed to remain permanently at the lower level, but the current account as a share of GDP is assumed to return to its baseline level after the shock (implicitly

assuming an offsetting adjustment in import levels)

${ }^{4}$ Includes official and private transfers and FDI.

${ }^{5}$ Depreciation is defined as percentage decline in dollar/local currency rate, such that it never exceeds 100 percent.

${ }^{6}$ Applies to all stress scenarios except for A2 (less favorable financing) in which the terms on all new financing are as specified in footnote 2. 
June 25, 2012

\section{IMF Executive Board Approves New US\$63.2 Million Extended Credit Facility Arrangement for the Central African Republic and US\$10.5 Million Disbursement}

The Executive Board of the International Monetary Fund (IMF) today approved a three-year arrangement under the Extended Credit Facility (ECF) for the Central African Republic in a total amount equivalent to SDR 41.775 million (about US\$63.2 million) to support the authorities' medium-term economic program. The Board's decision will enable an immediate disbursement of an amount equal to SDR 6.963 million (about to US\$10.5 million).

The authorities' program is aimed at consolidating macroeconomic stability by restoring fiscal discipline; creating fiscal space for increased spending on critical social programs and basic infrastructure; strengthening capacity and institutions; and accelerating structural reforms to remove impediments to growth. IMF support to the program acknowledges the fragility of the Central African Republic and seeks to catalyze donor financing and enhance coordination while helping the recovery and the authorities' reform efforts.

Following the Executive Board discussion on the Central African Republic, Mr. Naoyuki Shinohara, Deputy Managing Director and Acting Board Chair, issued the following statement:

"The Central African Republic authorities are to be commended for maintaining macroeconomic stability in a very difficult external environment, and for their commitment to fiscal consolidation geared at putting the public finances on a sound footing. As a fragile post-conflict state, the country faces daunting challenges that require the steadfast implementation of structural reforms to create fiscal space, strengthen administrative and institutional capacity, and improve the business climate to promote greater private sector participation in the economy.

"The authorities' economic program is closely aligned with the priorities of the secondgeneration poverty reduction strategy. This strategy aims at consolidating security and peace, boosting economic growth and regional integration, and advancing the development of human capital and essential social services. Its successful implementation is critical to help the Central African Republic progress toward the Millennium Development Goals. 
"The debt sustainability analysis shows that the country is at moderate risk of debt distress. The authorities therefore need to remain committed to pursuing prudent fiscal and borrowing policies, with new external debt contracted on highly concessional terms, to preserve debt sustainability.

"Renewed and concerted assistance from the IMF and the Central African Republic's development partners is crucial to support the economic recovery and boost the prospects for sustained growth and poverty alleviation."

\section{Background}

Growth in 2011 was stronger than previously estimated and inflation is accelerating. Real GDP growth has been revised upward to 3.3 percent for 2011 on the back of strong agriculture and mining activity. Reversing the downward trend since it peaked in 2008 ; inflation accelerated starting in November 2011 driven by price gouging and supply disruptions. As a result, headline inflation reached 7.8 percent in March 2012; but given price pressures are expected to ease later in the year, annual inflation would be contained at 6.8 percent for the year as a whole.

The program objectives are aligned with the strategic priorities of the second-generation Poverty Reduction Strategy Paper (PRSP II). In addition, C.A.R., along with six other countries, is part of a pilot for donors to implement a "New Deal" for engaging in fragile states and an integrated strategy is expected to be developed in Bangui, in September 2012. Key elements of the ECF program will be an essential part of the integrated strategy. A Consultative Group meeting is expected to be held before end-2012 to mobilize financing for the PRSP II. With the prospect of increased financing, the macroeconomic framework will be revised and efforts will be made with donors to identify "quick wins" that would bolster support for the government's reform agenda.

Real GDP growth is projected to accelerate to about 6 percent by 2014, on the back of continued strength in agricultural production; a recovery in private sector investment in the mining sector driven by foreign direct investment (FDI) inflows; and a rebound in external demand. Inflation is expected to return to levels within the CEMAC convergence rate of 3 percent starting in 2013. Natural resource exploitation over the medium term is expected to support growth and fiscal revenue. Projects underway include gold mining and petroleum exploration.

The fiscal program aims at generating modest domestic primary surpluses and putting the public debt on a downward trend as the government accelerates the clearance of domestic payment arrears and relies mostly on grant financing. The external current account deficit is expected to decline gradually in the medium term. This is predicated on a gradual improvement in the terms of trade and a pickup in FDI and official transfers as donors 
resume disbursement of external aid. However, while recovering modestly, the reserves position would remain weak with import coverage reaching just three months by 2014 .

The medium-term growth outlook is positive, but significant risks remain. They relate to a possible deterioration in the security and political situation and a weakening of the external environment, particularly in the euro area, C.A.R.'s main export market. 


\section{Statement by Mr. Assimaidou, Executive Director for Central African Republic \\ June 25, 2012}

The Central African Republic (C.A.R) authorities would like to express their appreciation to staff for the candid advice and the constructive policy dialogue during consultations held both in Bangui and Washington. They are also thankful to the Fund for the continued support to C.A.R, including through technical assistance.

C.A.R. faced a difficult environment, marked amongst others, by the global financial and economic crisis, a fragile socio-political environment and security challenges. With the assistance of the international community the authorities have sought to improve the security situation. They are also actively seeking resources to implement the recommendations of the Inclusive Political Dialogue, notably through a national unity government, and the revitalization of the Demobilization, Disarmament and Reintegration program.

Against this challenging background, the Central African Republic authorities have stepped up efforts to implement their poverty reduction and growth agenda. They have finalized the second-generation Poverty Reduction Strategy Paper (PRSP II) with broad stakeholders' participation. PRSP II is an ambitious and integrated set of reforms and projects aimed at accelerating growth and progress towards the Millenniums Development Goals. The authorities also took steps to consolidate the fragile economic recovery and, in close consultation with Fund staff, introduced measures aimed at reigning in the fiscal slippages which followed the protracted electoral cycle.

In order to mobilize the resources required to implement the PRSP II, the authorities intensified the pace of implementation of structural reforms and sought donors' reengagement in CAR. To accompany their comprehensive reform agenda aimed at fostering growth and reducing poverty while preserving macro-economic stability, they are requesting continued Fund engagement under a new ECF arrangement.

\section{Recent Economic Developments}

Driven by the primary sector, economic growth steadily increased, reaching 3.3 percent in 2011 following a modest 1.7 percent in 2009. Favorable weather conditions, as well as improved security in agricultural and livestock farming zones helped sustain this recovery. Inflation continued to decline to 1.2 percent in 2011.

Capacity constraints, as well as spending pressures related to the protracted electoral cycle engendered significant difficulties in budget execution. The authorities forcefully acted to restore fiscal discipline, and control spending while protecting priority spending. 
Hence, at the treasury, the recourse to exceptional payment procedures, the cash payment orders, was reduced from 80 percent of current expenditures in 2010 to 7 percent by end-2011. Efforts are being made to further reduce the use of these exceptional procedures with the goal of containing them to within 5 percent of current expenditure. Faced with increasing imported oil prices, the authorities implemented another upward adjustment to pump prices on June 2012, in order to safeguard the budget.

As regards external payment arrears, the authorities are pursuing efforts to reach debt rescheduling and cancelations agreements with the remaining creditors on HIPCs terms. They have cleared payment arrears to Paris Club creditors, as well as to multilateral institutions. The authorities also requested technical assistance to audit domestic debt arrears, with the view to clearing them.

On structural reforms, the authorities implemented reforms aimed at strengthening their institutional capacity for macroeconomic policy implementation, as well as public financial management. In line with Fund advice, they streamlined and reorganized institutions for economic governance to improve their effectiveness.

Along these lines, they sought to revitalize the Liquidity Monitoring Commission, and installed the Budget Management and Monitoring Commission (CSGB) which monitors on a bimonthly basis budget execution to prevent the recurrence of fiscal slippages. These commissions are now fully operational.

The authorities also strengthened revenue collection agencies, including by streamlining the registration process for taxpayers. Efforts were also made to improve economic governance through increased transparency, including by implementing the treasury single account and implementation of EITI's recommendations which allowed CAR to maintain its compliant member status under this initiative.

\section{Medium-Term and 2012-2013 Policies}

The authorities' medium-term policies will be guided by the priorities of the PRSP II, and will include four strategic pillars: i. the consolidation of macroeconomic stability, ii. mobilization and scaling up of resources for priority spending, iii. capacity building, both human and institutional and iv. removing constraints to growth.

Going forward, the authorities expect the recovery to firm up, as security and sociopolitical stability are consolidated, aid flows resume, and investors regain confidence. Within this overall framework, growth in 2012-13 is expected to recover steadily as the impact of the crisis withers away, and the countries' natural resources potential, especially in the mining and forestry sectors is developed. Inflation is expected to return within the CEMAC's convergence criteria boundary after spiking in 2012, while the 
current account position will remain fragile reflecting the need for increased imports notably of equipment goods, and unfavorable terms of trade.

\section{Creating Fiscal Space for Priority Spending}

The authorities' fiscal program aims at mobilizing and reallocating resources towards spending identified as essential under the PRSP II.

In order to increase revenues, the authorities will implement reforms to modernize customs and tax administration. Tax reforms will be geared toward broadening the tax base, and enhancing compliance, including by updating taxpayers' identification system, improving the taxation of small and medium size enterprise, and modernizing SYSTEMIF, the tax administration information system. In order to protect the budget from increased oil prices, the authorities intend to continue adjusting domestic petroleum prices to reflect international oil prices fluctuations with the view to eliminating untargeted subsidies. They have requested technical assistance from the Fund to review and streamline further the petroleum product price structure.

As regards customs reforms, the authorities will implement the modernization plan in close partnership with the World Customs Organization. They also plan to open new customs clearance centers, and upgrade the equipment of customs offices, as well as reduce customs exemptions.

The authorities will also intensify efforts to reallocate resources towards priority spending particularly to address basic infrastructure needs, such as energy and roads, as well as social spending. At the same time they will seek to improve spending efficiency, including through public financial management reforms. On public financial management, the authorities will focus on improving the management of liquidity and budget execution. In that regard the CSGB will meet on a bimonthly basis to review and update binding spending commitment plans. In addition to bimonthly spending commitment caps, the authorities are also determined to limit the recourse to exceptional payment procedures.

They will further streamline the expenditure chain, improve budget control processes, and will make full use of the potential of the GESCO expenditure management system, including by extending its coverage to the Treasury departments operations.

\section{Debt policies}

The authorities are committed to implement prudent debt policies to preserve hard gained debt sustainability post- HIPIC completion point. They will seek to enhance debt 
management capacity, including by strengthening the Debt and Equity Participation Unit, and through the establishment of the National Committee on Public Debt.

\section{Financial sector policies}

The authorities will intensify reforms to expand access to financial services especially beyond the capital city. They are actively seeking a strategic investor to reduce their participation in the intervened bank. They are closely monitoring the compliance of the financial system with regional prudential ratios.

\section{Structural reforms}

Structural reforms actions will be directed to improve the CAR's economy's competitiveness and leverage the contribution of the natural resources sector to accelerate growth and diversify production. In this regard, the authorities will undertake reforms to improve the climate for business, and promote private sector development. They will continue efforts to strengthen the judiciary, and enhance the security of property and contractual rights. They will also review the investment charter to make it more attractive for foreign direct investment.

The authorities are also committed to improving economic governance and building human and institutional capacity, in order to make the most of limited public resources. They will seek to improve transparency by centralizing cash management and implementing the treasury single account, and by regularly publishing the budget law.

With respect to public enterprises, the authorities intend to phase out the exceptional receivership measures taken early this year which uncovered financial mismanagement in these enterprises. While normalizing the management of state-owned enterprises, the authorities are determined to enhance their oversight, and strengthen their balance sheets.

\section{Conclusion}

The Central African Republic's authorities have demonstrated their dedication to sound economic and financial policies, notably by taking strong corrective actions to restore fiscal discipline. The authorities continue to face daunting challenges as they seek to achieve their growth and poverty reduction goals, which are compounded by capacity constraints, and socio-political unsteadiness.

To address these challenges, my authorities, have put in place a comprehensive reform program for which they are requesting Fund's assistance under the ECF. In light of the prior actions taken and the authorities' commitment to adhere to sound policies going forward, and the measures already implemented, I would appreciate Directors' support to my the authorities request for a new ECF-supported program. 